Historic, Archive Document

Do not assume content reflects current scientific knowledge, policies, or practices. 

1903

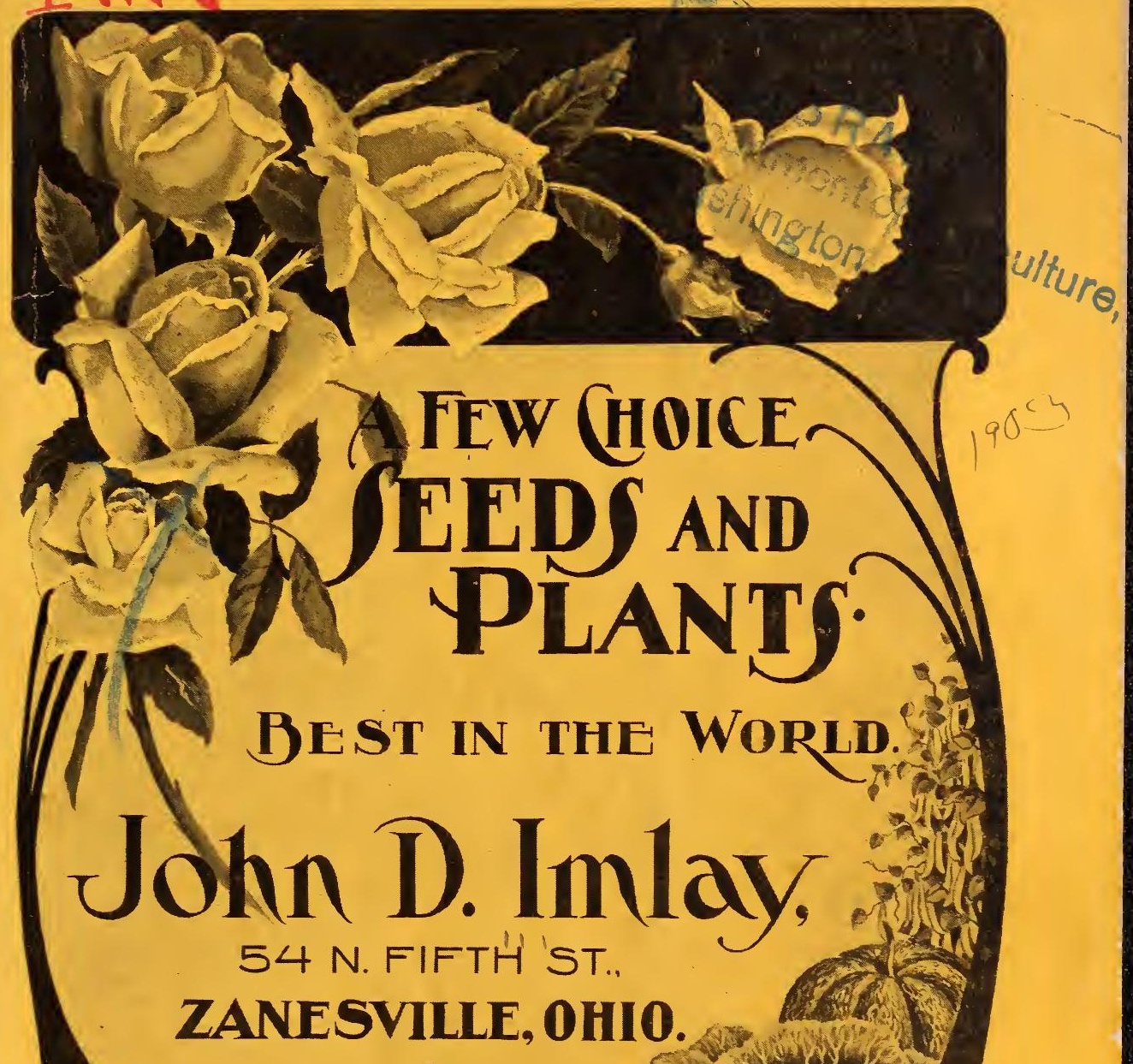




\section{IMLAY'S CATALOGUE OF SEEDS AND PLANTS.}

Zaxestille, Ohio, February 1, 1903.

Please show this Catalogue to your friends, and if you should receive an extra copy be kind enough to hand it to some neighbor interested in seeds, who will be glad to get it. I will be glad to send a copy free to any of your friends in this or any other country likely to want seeds. In return I will ask you to speak a gond word for me to your friends and neighbors. An order this season, no matter how small, secures my next Catalogue as soon as issued.

CUSTOIERS WHO ORDER EARLY have their seeds on hand when they want them, and aroid unnecessary delar during the rush of the busy season. Make out your order as soon as rou receive our catalogue, and remember that heary seeds and large quantities can be sent cheapls by freight, and will reach you in time if ordered early.

CHANGE OF ADDRESS. - If , ou bave changed, or intend to change your address, please let me know, and I will change it on $m y$ books, so that you will receive my Catalogue without application, at your new address.

LARGE ORDERS. - Any market gardener, institution or individual wishing seeds in large quantities, is requested to mail me a list of what they want, and I will promptly return it, with the very lowest prices marked. A letter of inquiry may save you dollars if you want to buy in quantity.

TERIS. - II $y$ terms are strictly eash. Remittances should accompany all orders.

PRICES.-Prices are quoted by the packet, ounce, pound, quart and bushel. They are the ruling prices at this date, and do not include cost of trausportation, except as noted below.

POSTAGE.-I send postpaid, to any postoffice in the United States, all packets and ounces of Flower and Tegetable Seeds (Beans, Peas and Corn excepted.) On all seeds by weight where quantity exceeds that abore mentioned, $8 \mathrm{c} \mathrm{lb}$. must be added for postage. On Corn, Beans and Peas, 8c per pint and 15c per quart must be added for postage. All seeeds or plants by express or freight will be sent at the expense of purchaser.

PACKING.-I make no charges for boxes, barrels or packing, or delivery to depots, boats or express offices.

BAGS. - When bags are required, they are charged at cost only.

REMITTANCES.-Remittances may be made by New York Draft, Postoffice Money Order, Registered Letter or by Express.

ADDRESS.-In ordering, be particular to sign your name, postoffice, county and state plainly, also mention the mode of transportation you prefer-whether by mail, express or freight.

WARRANTS.-There are hundreds of contingencies continually arising to prevent the best seeds always giving satisfaction, and for this reason J wish to state explicity, that while I have used the greatest care in the selection of my stock, to have it true to name, pure and reliable, $\mathrm{m} y$ seeds are sold without any warranty, express or implied, and without any responsibility in respect to crop.

\section{JNO. D. IMLAY, 54 North Fifth Street, Zanesville, 0.}




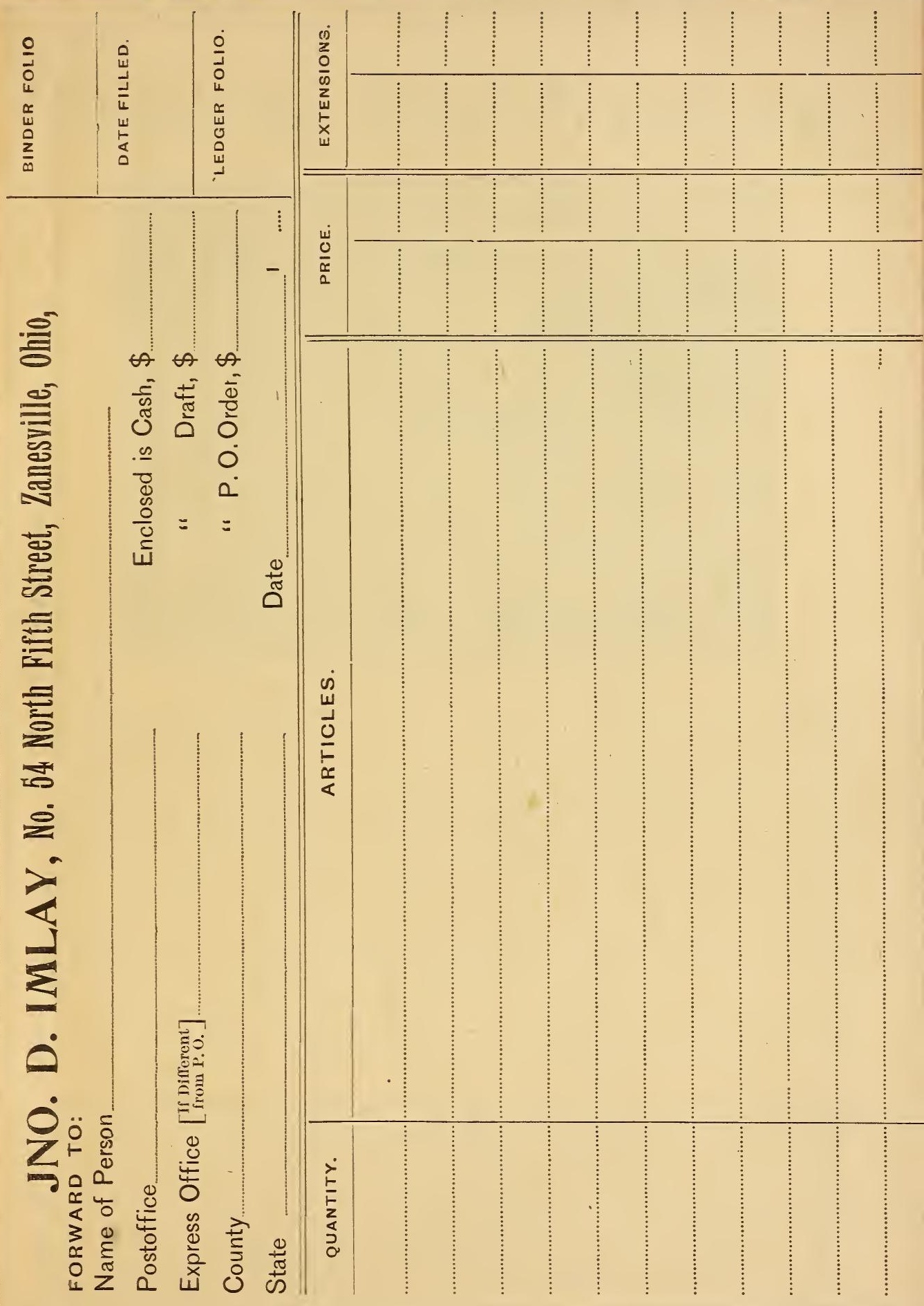





\section{Superior Seed Potatoes.}

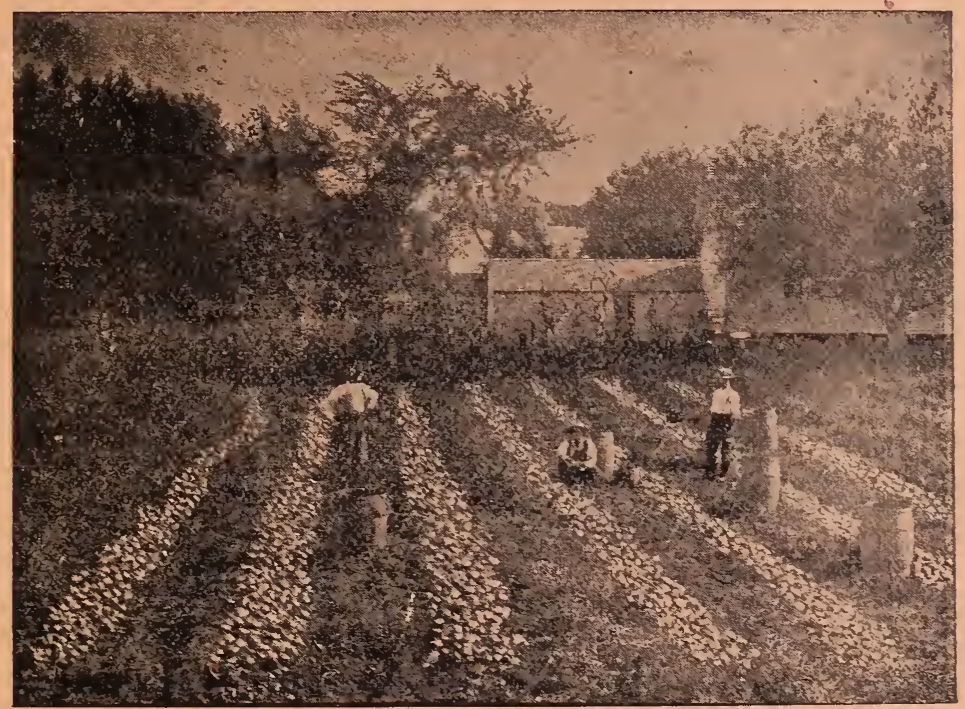

IT PAYS TO CHANGE SEED EVERY YEAR.

The necessity of changing Potato Seed often is unirersally admitted by all the well posted growers, but too seldom practiced, especially when the best sepd can he had at so little additional outlay. About eight bushels will seed an acre, and at $25 \mathrm{c}$. to $40 \mathrm{c}$. per bushel additional cost, the whole outlas would be $\$ 2.00$ to $\$ 3.00$, with an increase in the crop of at least 25 per cent. By using our Northern Grown Seed you are assured of early maturity, an increased yield and vigorous growth. Our northern growers are potato specialists, and the growth and extent of our trade is the result mostly of the grower's' painstaking care and general knowledge in growing and selecting seed stock. They use first-class potato land, rell matured, good-sized seed, treating the seed and spraying the foliage when necessary, and fighting bugs and blight from start to finish, because potatoes fit for seed cannot be produced from unhealthy, injured foliage. The potatoes are rery carefully handled when digging and barreling.

EARLY ORDERS.-Ererything points to a lively demand for choice seed potatoes this season, and while we have a good stock in store at present, we would advise our customers to order early. Be sure and gire plain shipping directions.

\section{Red River Early Ohio. Early ohio is witlout doubt the}

country. Every one knows what it is, and that it can be relied upon for an early market variets in almost erery locality. Better decide to have some of the best new stock of seed this year, and order some of our famous Red Rirer Early Ohios. The illustration on page 23 is from a photograph, showing just how they look, and we know it pars to plant Red Rirer seed, eren should it cost double. It alwars groms so strong and rigorous and produces so much more than any home seed, maturing the crop in a shorter time, too, while its tubers are fine and smooth, free from prongs and scab. This rear we hare secured a car lot of the very finest, and our grower in the Red Rirer valles says of the Early Ohios shipped us for this vear:- "The lot, as a whole, is the best we ever shipped. The potatoes ripened perfectly before frost came, and that makes them look bright and nice." Prices: By mail postpaid, 20c lb; $3 \mathrm{lbs}$. for $45 \mathrm{c}$. By express or freight: $10 \mathrm{c}$ lb., $25 \mathrm{c} 1 / 2$ peck, $40 \mathrm{c}$ peck, $\$ 1.20$ bushel, $\$ 3.00$ barrel. 
The introducer, J. C. Vaughan, pushed this variety hard last year, declaring it to be the "greatest winner in new potatoes for ten years." It seems that four years ago a western grower found one plant in a field of Early Olio that produced white potatoes.

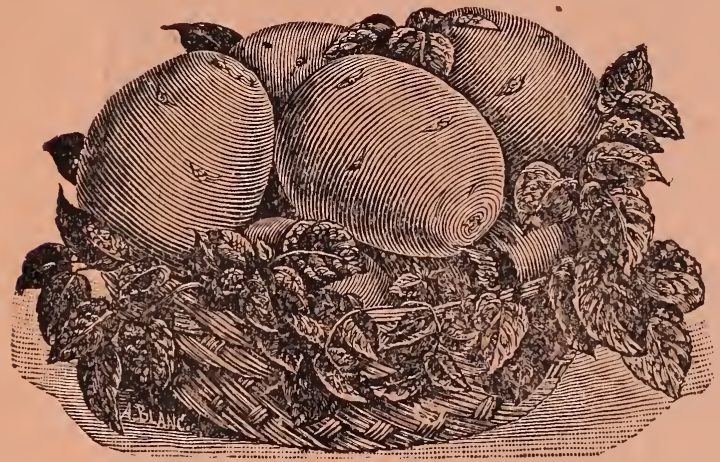

Vaughan's White Ohios are all from that one hill, and he claims to have eliminated the split ends and increased its yielding qualities one-third, and a white potato takes the preference in almost every market. So that a genuine Early Olio with a white skin is sure to succeed, and will be much sought after. Our stock, purchased from the introducer, is choice Red River grown. You will surely want some this year. 20c. per lb. by mail, 3 lbs. for $45 \mathrm{c} ; 25 \mathrm{c} 1 / 2$ peck, $40 \mathrm{c}$ peck, $\$ 1.20$ bushel, $\$ 3.00$ barrel.

\section{Red River Triumph.}

Bliss' Triumph is the earliest of all the early varieties, and the leading early variety all tlirough the soutl. We are all familiar with it as sold at the groceries when the first new potatoes are shipped in. The tubers are nearly round, smooth, medium in size, and reddish pink in color. Vines are small and compact, with short, thick stalks and broad leaves. No other variety will mature a crop so quickly. Red River grown Triumph are extra large and fine, away ahead of any Triumph we ever saw grown here. All our planters know the great value of northern grown seed, and you will surely want a barrel of our Red River stock. 40e peck, $\$ 1.20$ bushel, $\$ 3.00$ barrel.

Hewes' Early.

This new seedling is evidently a member of the Ohio family, and resembles the Acme and Early Six Weeks in habit of stalk and bloom. It is extremely early, very free from mixture with other kinds. Planters whose soil and market use potatoes of the Ohio class to advantage make no mistake planting this. $40 \mathrm{c}$ pk., $\$ 1.20 \mathrm{bu}$., $\$ 3.00 \mathrm{bbl}$.

\section{Northern Grown Early Rose. The old and popular Northern Grown Early Rose. $\begin{gathered}\text { standard early po- } \\ \text { tato noted for its }\end{gathered}$} earliness, productiveness and fine quality. We have a good supply of Michigan grown seed, and if your crops of Early Rose have not been all that you desired, try Northern Grown Seed for another season, and secure increased vigor and earliness. $40 \mathrm{c}$ peck, $\$ 1.20$ bushel, $\$ 3.00$ barrel.

COLLECTION BARRELS. We will make up a barrel of any two varieties COLLECTION BARRELS. on list (half of each) at barrel rates and $10 \mathrm{c}$ extra, or three varieties (one-third of each) at barrel rates and 15c extra. Only one variety will be placed in a barrel loose, the rest being in sacks. We use barrels of large size for such orders, as the sacks take up extra room. Remember, a barrel proper is always 165 pounds, no more, no less. We weigh every barrel. Our large barrels will hold four bushels of one variety, or about $3 \frac{1}{2}$ bushels of three or four varieties, if filled full. We have plenty of these barrels, and in packing them the surplus space, if any, is filled with hay or straw. If you want quite a list of different varieties, we will quote you prices, but in writing tell us exactly what you want and the quantity of each.

OUR PRICES.-The prices quoted are about what we think will rule for good and straight unmixed stock, but if you receive lower quotations, write us what you want and we will bid for your order. You may save dollars. While we can frequently do better than other firms, we do not care to compete with irresponsible commission houses who scarcely know one potato from another. Buyers of large quantities should write us, stating their needs, and we will make prices that will result in trade. 


\section{SEEDS IN SMALL QUANTITIES.}

It had seemed to us for some time that the old plan of selling Vegetable Seeds in packets lacked definiteness, and was not a satisfactory one for the purchaser. There was no given rule as to the quantity of seed put in a packet by various seedsmen, each

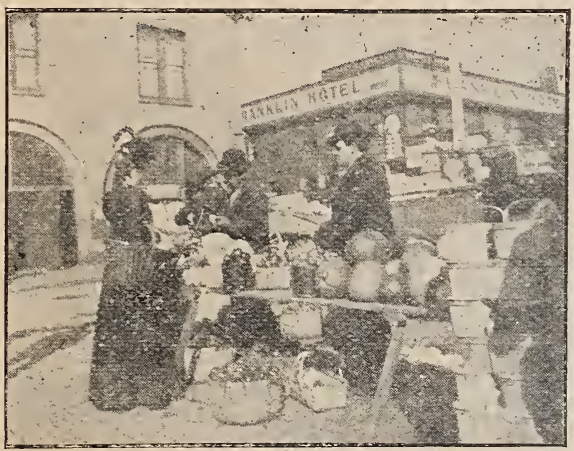

FAMILIAR MARKET SCENE:

Making a Purchase of Vegetables Grown from Our Superior Seed. using his own measure; and consequently purchasers had no means of knowing: how much ground a packet would plant, and is a rule, we believe, the quantity was not sufficient for ordinary needs. Therefore, four years ago we adopted a new system, giving

\section{DEFINITE QUANTITIES FOR FIVE CENTS,}

increasing from small packets to ounces and fractions of an ounce on all leading varieties of Vegetable Seeds, according to cost, thus enabling our patrons to know just what they will receive. This proved very satisfactory, and by referring to the directions at the head of the various sorts, Beans, Peas, etc., will be found the quantity of seed required for a given amount of space. Our customers will also note that we have, in giving the large amount of seed, likewise increased the cost of postage or delivery, and in consideration of this liberality and extra expense to ourselves, we trust you will evince your appreciation by an increase in your order.

\section{ASPARAGUS.}

One ounce of seed sows sixty feet of drill. About 400 plants to the ounce. By purchasing good strong plants, one to two years' time is saved. A bed $15 x 50$ feet, requiring 100 plants, supplies a family.

Palmetto. Early, a good yielder and even grower. $5 \mathrm{c} 1 / 4 \mathrm{oz}, 10 \mathrm{c} \mathrm{oz}, 60 \mathrm{c} 1 \mathrm{~b}$. Roots by mail postpaid-50 for $70 \mathrm{c} ; 100$ for $\$ 1.25$; by express (not prepaid) -100 for $75 \mathrm{c} ; 500$ for $\$ 3.50 ; \$ 6.00$ per 1000 .

Barr's Mammoth. Very large and uniform, grows very quick, and very light in color. Јૅ $1 / 4 \mathrm{oz}, 10 \mathrm{c} \mathrm{oz}, 60 \mathrm{c} 1 \mathrm{~b}$. Roots by mail posüpaid-50 for 7() $\mathrm{c} ; 100$ for $\$ 1.25 ; \mathrm{by}$ express (not prepaid) -1.00 for $75 c ; 500$ for $\$ 3.50 ; \$ 6.00$ per 1000 .

\section{BEANS.}

If by mail, please add 8c. per pint, 15c. per quart. - One quart will sow one hundred feet of drill. One and one-half bushels to the acre.

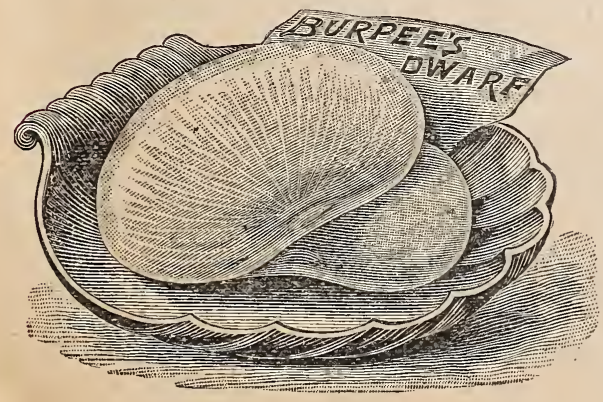

BUSH LIMA-Dwarf Large White. (See cut.) Absolutely true from seed, bushes 18 to 20 inches high, very stout and erect, each plant branching vigorously and developing into a magnificent circular bush two or three feet in diameter, with no disposition to run. Thick main stalk and large branches, healthy green color, leathery leaves, indicating a strong constitution. Sure cropper and immense yielder, each bush bearing 50 to 200 large pods well filled with beans, in size and flavor identical with large Pole Limas. $8 \mathrm{c} \frac{1}{2}$ pint, $15 \mathrm{c}$ pint, $25 \mathrm{c}$ quart. 


\section{BEANS-Dwarf Wax, Yellow Pod, Snap or String.}

Jones' Stringless White Seed Round Pod Wax. This absolutely stringless bean of bush-type is a week earlier than any other variety. The pods form very quickly, and are long. perfectly round and exceptionally solid, of a delicate light color, and free from rust. $8 \mathrm{e} \frac{1}{2}$ pint, $15 \mathrm{c}$ pint, $25 \mathrm{c}$ quart.

Improved Golden Wax. This standard variety still retains its popularity, there being no better snap bean for general cultivation. Pods long, nearly straight, flat and broad, golden yellow, very thick or fleshy and wax-like. Beans medium in size, white, and more or less covered with purple shading. $8 \mathrm{c} \frac{1}{2}$ pint, $15 \mathrm{c}$ pint, 2 se quart.

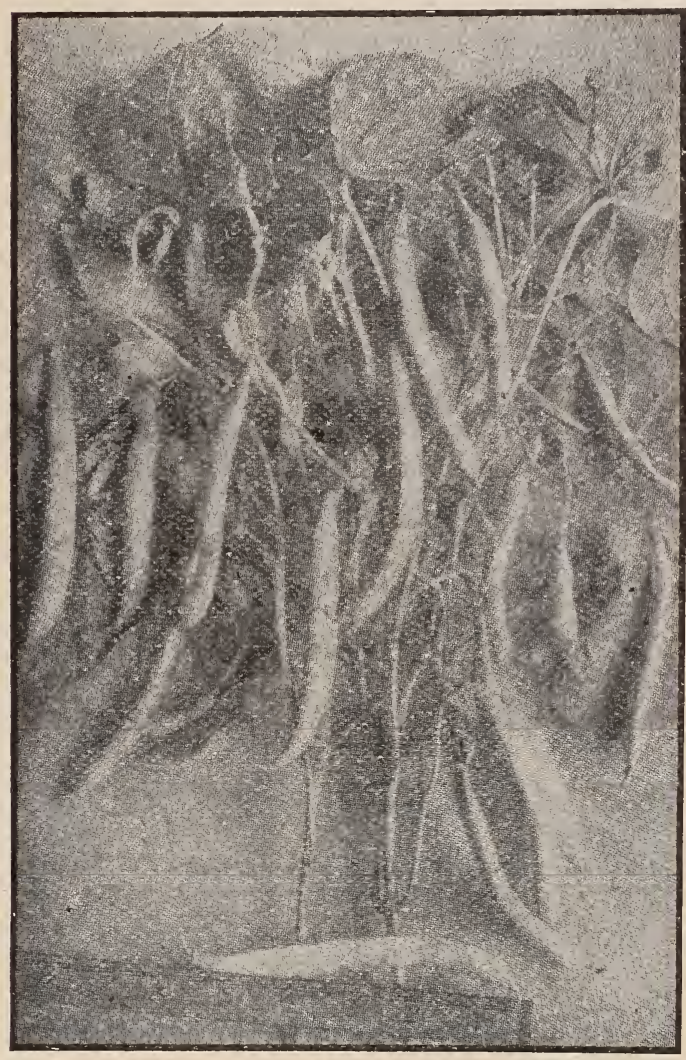

Challenge Black Wax.

\section{Challenge Dwarf Black Wax} (See cut.) Experience proves the great merit of this variety, the enormous demand showing that it meets popular requirements and lias all the sterling qualities claimed for it. It has been found unexcelled in quality and the first to give a full picking of pods, consequently it is the best early wax bean for the market garden. In growth and general appearance the plants are the same as the old Black Wax or Butter Bean. The pods are clear, waxy-white, quite round, very fleshy, crisp, tender and stringless. The dry bean is jet black, longer, more curved and flatter than the Prolific German Wax. 8c $1 / 2$ pint, $15 \mathrm{c}$ pint, 25e quart.

Davis Wax. Wonderfully productive, very vigorous and hardy vines of upright growtl, holding the pods well up from the ground, practically all being handsome and straight. It has no superior as a snap bean, being ver'y crisp, tender, stringless and stands shipping well. Pods long, straight and white, and white beans. $8 \mathrm{c} \frac{1}{2}$ pint, $15 \mathrm{c}$ pint, 25 c quart.

Detroit Wax. Rust-proof and splendid sort for shipping. Long, straight, handsome pods that keep a long time without spoiling. This has become a favorite with some. $8 \mathrm{c} 1 / 2$ pint, $15 \mathrm{c}$ pint, $25 \mathrm{c}$ quart.

Wardwell's Kidney Wax. Very hardy and best for long distance shipping. Very prolific, with long, flat pods. $8 \mathrm{c} \frac{1}{2}$ pint, $15 \mathrm{c}$ pint, $25 \mathrm{c}$ quart.

Prolific Dwarf German Black Wax. Popular first-early snap sort, with round yellowish-white pods of very fine and delicate flavor. $8 \mathrm{c} \frac{1}{2}$ pint, $15 \mathrm{c}$ pint, $25 \mathrm{c}$ quart.

\section{FOR SHELLED BEANS-GREEN PODS.}

Large White Marrow or Mountain. Valuable as a string bean, but extensively grown for winter use. Beans are large, clear white, cooking very dry and mealy. $10 \mathrm{c}$ pint, 20c quart, $\$ 3.50$ bushel.

White Kidney. (Royal Dwarf.) Excellent shell bean for use in succotash, and one of the best for winter use; also unsurpassed for baking. Beans large, long, white and kidney-shaped. $10 \mathrm{c}$ pint, $20 \mathrm{c}$ quart, $\$ 3.50$ bushel.

White Navy or Pea Bean. Well known productive and standard sort. $10 \mathrm{c}$ pint, 20 c quart, $\$ 3.50$ bushel. 


\section{BEANS-Dwarf, Snap or Bush.}

Under this head are classed all the low-growing sorts, variously called Bush, Snap and String-Green Pods.

New Giant Green Pod Stringless Valentine Bean. The Round Pod Talentine has long been one of the most popular, but outside of slightly improving the existing trpe, nothing to materially better it has been achiered until we are now much gratified to be able to offer this distinct new cross-bred rariety as one possessing all the merits of the old farorite, with the following additional points to enhance its ralue: Ready a week earlier with a more prolific crop, pods a third larger, a veraging fice to six inches in length; absolutely stringless, round, full and fleshy, mole prolific, and surpasses others in erispness and flaror. No gardener should miss planting it this year. \&c $1 / 2$ pint, 150 pint, 25e quart.

Longfellow Green Pod. Long green pods, exceedingly prolific, delicious in flavor, always solid, wonderfully tender, remarkably early and an ideal string bean. Pods are $61 / 2$ inches long pale, soft green in color, perfectly straight and round, free from woolly inner-lining, and what little string exists is not developed until the pod is quite old. Its flaror is delicious, delicate color intact when prepared for the table, remarkably early and ready for use four days in adrance of any other variety of merit, while its bearing qualities are unexcelled. $8 \mathrm{c} \frac{1}{2}$ pint, $15 \mathrm{c}$ pint, $25 \mathrm{c}$ quart.

Stringless Green Pod. (See cut.) Many growers believe this is destined to replace the Valentine, which it leads in earliness, while the pods are longer and straighter, and fully as round and fleshy, as well as absolutely free from string. "It has every good quality of the Talentine, and is one week eariier. 8c $1 / 2$ pint, $15 \mathrm{c}$ pint, $25 \mathrm{c}$ quart.

Early Red Valentine, Improved Round Pod. Nothing better for snaps among the green-podded sorts. Many different strains are offered under slightly rarying names, each claiming to be a distinct improvement, but we are not yet willing to substitute them for our old stock, which combines to a high degree all the good qualities of the green-podded sorts. $8 \mathrm{c} \frac{1}{2}$ pint, $15 \mathrm{c}$ pint, $25 \mathrm{c}$ quart.

Early Mohawk. Very early and stands more cold than most of the bush varieties, being largely grown in the south for northern markets. The pods are fire to six inches long, and the ripe seeds purple with white spots. $6 \mathrm{c} 1 / 2$ pint, $10 \mathrm{c}$ pint, $20 \mathrm{c}$ quart.

Refugee, or Thousand=to $=$ One. This is a rery productive rariety, but medium to late in bearing. The rines are large and spreading; the young pods tender and of fine flaror, long, cylindrical and green. The beans are a dull yellow in color, spotted and speckled with purple. The pods are thick-fleshed and much used for pickling. $6 \mathrm{c} \frac{1}{2}$ pint, $10 \mathrm{c}$ pint, $20 \mathrm{c}$ quart.

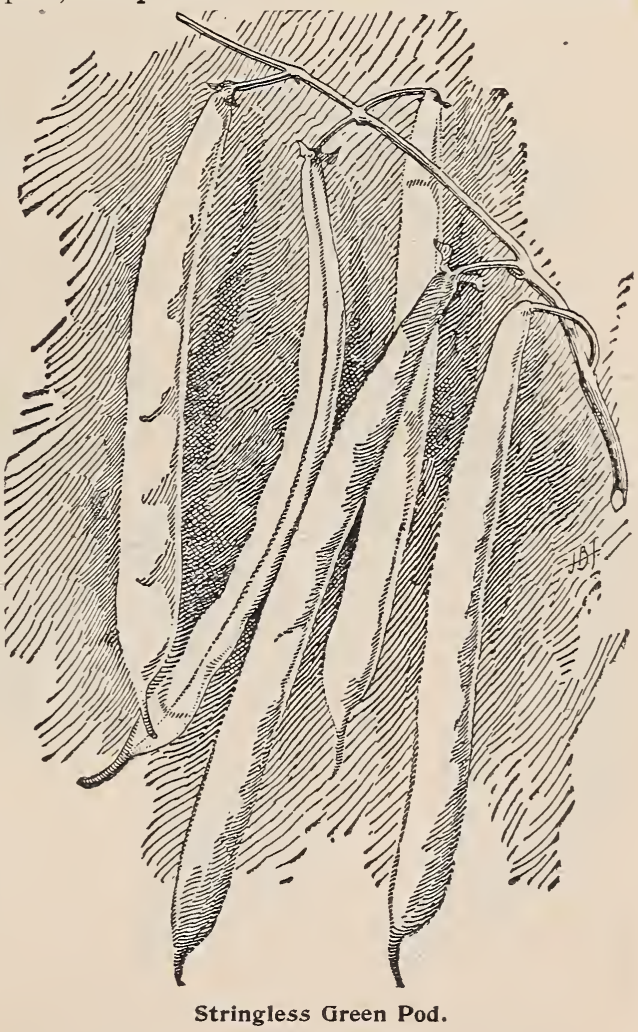

Extra Early Refugee. An early green pod, furnishing a fleshy pod of rery fine quality, which can usually be picked as soon as Golden or Detroit Wax, and one to two weeks earlier than ordinary Refugee. The vines, though smaller, are fully as hardy and rigorous, and more upright growing. Pods are of the same size and shape, except slightly flatter, while the dry beans are the same, and all the pods ripen well together. $6 \mathrm{c} \frac{1}{2}$ pint, $10 \mathrm{c}$ pint, $20 \mathrm{c}$ quart.

Early China. Pods of good quality if picked young. Beans excellent, either green or dry. 6e $\frac{1}{2}$ pint, $10 \mathrm{c}$ pint, $20 \mathrm{c}$ quart. 


\section{BEANS-Pole or Running.}

One quart will plant fifty hills. If by mail, add 15c. per quart.

Golden Cluster Wax Pole. Tndoubtedly the earliest of the pole rarieties, seren to ten days behind Dwarf Golden Wax. It begins to bear early and continues until frost. The pods are from six to eight inches long, borne in clusters of three to six, and are most freely produced. They are stringless, rery tender, of delicious fla ror, with white seed. $8 \mathrm{c} \frac{1}{2}$ pint, $15 \mathrm{c}$ pint, 2 こ̌c quart.

Lazy Wife. Best and largest green-podded pole bean, with pods from four to six inches long, entirely stringless, and of rich buttery flaror when cooked; pods remain green and retain their tender, rich flavor until nearls ripe. Beans white and are unsurpassed for winter use when shelled. $8 \mathrm{c} 1 / 2$ pint, $15 \mathrm{c}$ pint, $25 \mathrm{c}$ quart.

Kentucky Wonder. Splendid rariety, sold as Seek-no-further, Old Homestead, etc. Very productice, green pods in large clusters, nine or ten inches long, and excellent for snaps. Dry bean long, oral and dun-colored. $8 \mathrm{c} \frac{1}{2}$ pint, $15 \mathrm{c}$ pint, $25 \mathrm{c}$ quart.

Horticultural, or Speckled Cranberry. An old farorite, equally good as a snap, or shelled, green or dry.' 8c $1 / 2$ pint, $15 \mathrm{c}$ pint, $25 \mathrm{c}$ quart.

Cut Short, Red Speckled or Corn Hill. Old variety, for planting among the corn. Pods short, cylindrical; beans oblong, ends cut off diagonally. $8 \mathrm{c} \frac{1}{2} \mathrm{pt}, 15 \mathrm{c}$ pint, $25 \mathrm{c}$ qt.

POLE LIMAS.

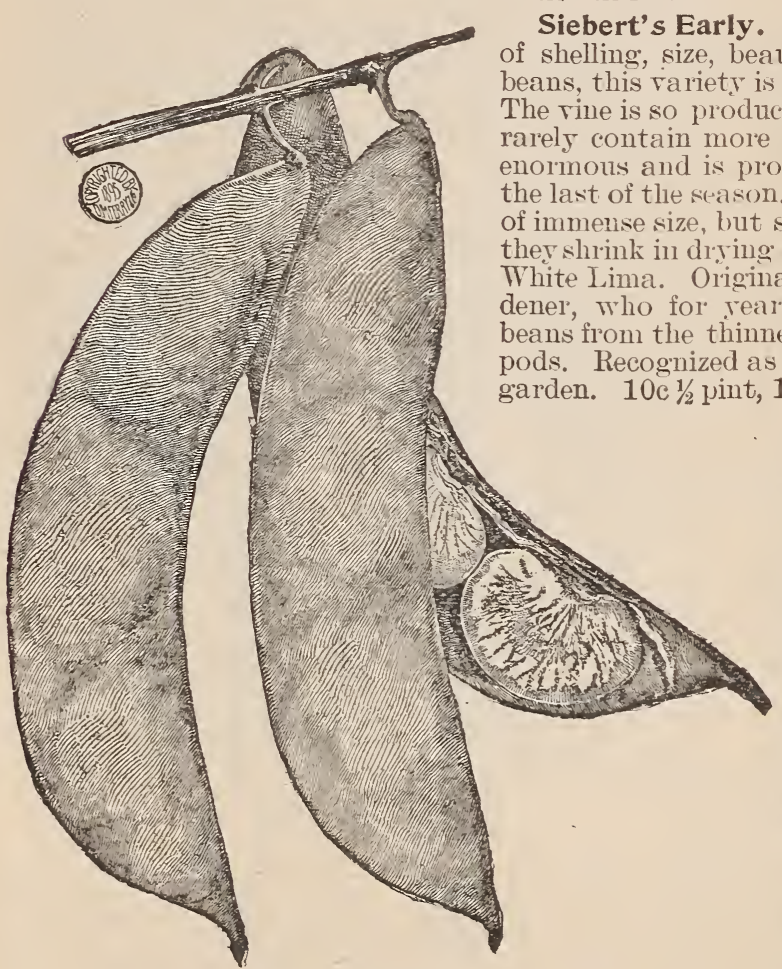

Siebert's Early Lima.

(See cut.) In earliness, ease. of shelling, size, beauty and quality of the green beans, this rariety is far in advance of all other's. The rine is so productive that although the pods rarely contain more than four beans, the yield is enormous and is produced from the rely first to the last of the season. The green shelled beans are of immense size, but so tender and succulent that they shrink in drying to about the size of the Large White Lima. Originated by a skillful marketgardener, who for rears selected the largest green beans from the thinnest and most easily opened pods. Recognized as the best Lima for niarket or garden. $10 \mathrm{c} \frac{1}{2}$ jint, $15 \mathrm{c}$ pint, $25 \mathrm{c}$ quart.

Ford's Mammoth. The result of orer twenty sears' selection by Jas. Ford, one of the oldest market gardeners around Philadelphia. The pods grow to an a rerage length of eight inches, and are produced in great cluster's, with from fire to seren beans per pod, of most excellent quality, green or dry. Fines set beans early at the bottom of the pole and bear right up to frost. $8 \mathrm{c} \frac{1}{2}$ pint, $15 \mathrm{c}$ pint, $25 \mathrm{c}$ quart.

King of the Garden. Vine rers rigorous and productive and pods of largest size, filled with four or fire immense white beans. $8 \mathrm{c} \frac{1}{2} \mathrm{pt}$, $15 \mathrm{c}$ pint, $25 \mathrm{c}$ quart.

Extra Eariy Jersey. Pods are large and numerous, invariably having four to fire beans in each. This rariety appears in Philadelphia markets nearly two weeks ahead of the ordinary Limas, selling at from $\$ 3.00$ to $\$ 1.00$ per bushel of pods, and previous to the introduction of Siebert's Early, was considered the earliest and best. $8 \mathrm{c} 1 / 2$ pint, $15 \mathrm{c}$ pint, $25 \mathrm{c}$ quart.

Large White Lima. Tine tall growing, vigorous and slender, with smooth, light green leares of medium size, and small white blossoms. The pods, borne in clusters, are long, broad, rery thin and dark green. Beans are large, flat, kidney-shaped and greenish-white. $8 \mathrm{c} \frac{1}{2} \mathrm{p}$ pint, $15 \mathrm{c}$ pint, $25 \mathrm{c}$ quart. 


\section{BEETS FOR THE TABLE.}

One ounce of seed to one hundred feet of row. Ready for the table 40 to $\%$ days from sowing.

Crosby's Improved Egyptian. This new and superior beet has grown in faror so rapidly among our customers that sometimes we have been unable to fill orders receired late in the season. It is a rerr superior strain of the well known Egrptian, carefully selected for rears by Mr. Josiah Crosby, a well known eastern market gardener, from whom we obtained our orginal stock seed. Handsome form, good size, fer and small tops, fine quality. deep blood red color, and quick, rapid growth: takes on its turnip shape and looks well eren in the early stages of growth. Does not become woody and tasteless, and mar be sown outside as late as Julc. No market or family gardener who ralues earliness should fail to grow this raluable beet, and the genuine seed cannot be obtained at a lower price. $5 \mathrm{c} \frac{1}{2} \mathrm{oz}, 10 \mathrm{c} \mathrm{oz}, 25 \mathrm{c} 1 / 1 \mathrm{lb}$.

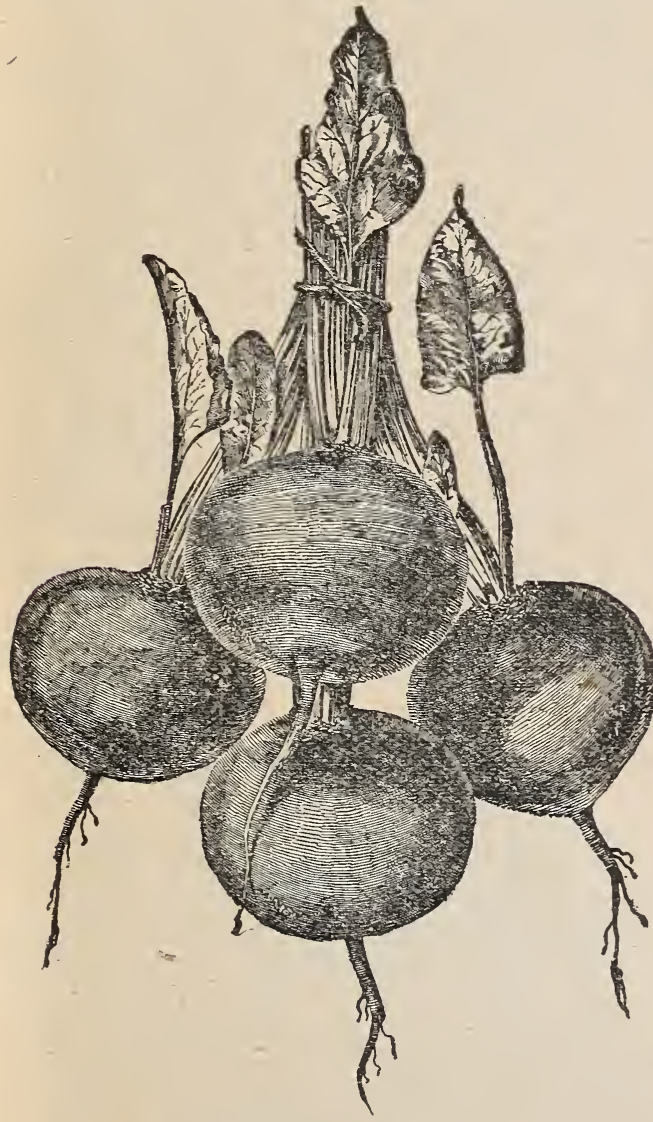

Detroit Dark Red.

Detroit Dark Red Turnip. (See cut.) $\mathrm{Br}$ far the best red turnip beet in cultiration; rers handsome, perfect in form, beautiful deep bright red in color, crisp, tender and sweet; early to mature, and holding a long time in condition to use. The stock we offer will produce a crop more uniform in shape, color and quality than any other. $5 \mathrm{c} \frac{1}{2} \mathrm{oz}, 10 \mathrm{c} \mathrm{oz}, 25 \mathrm{c} 1 / 1 \mathrm{lb}$.

Edmand's Early Red Turnip. A splendid new rariets, originated near Boston: not as early as some, but has many fine qualities to commend it; most uniform of all turmip beets, of handsome, round shape, good marketable size, and deep blood red color. $5 \mathrm{c} \frac{1}{2} \mathrm{oz}, 10 \mathrm{c} \mathrm{oz}, 25 \mathrm{c} 1 / 1 \mathrm{lb}$.

Improved Eclipse. Is pronounced by hundreds of gardeners the earliest and best. Fine color, globular, with very small tops; very sweet, crisp and tender when young. $5 \mathrm{c} 1 / 2 \mathrm{oz}, 10 \mathrm{c} \mathrm{oz}$, $25 \mathrm{c} 1 / 1 \mathrm{lb}$.

Half Long Blood. Fills the place among late beets occupied br Detroit Dark Red among the early sorts, and is so superior that any one once using it will not care to try anything else. It is of fine form, exceedingly rich and beautiful in color, quality of the best, and so good a keeper that it can be stored and furnished at any time throughout the winter as crisp and tender as if fresh from the garden. $5 \mathrm{c} 1 / 2 \mathrm{oz}, 10 \mathrm{coz}, 25 \mathrm{c} 1 / 1 \mathrm{lb}$.

Bassano. Large tops, bright red leaf stems, light green leares, large roots, round and turnip-shaped; pink flesh, zoned with white. $5 \mathrm{c} 1 / 2 \mathrm{oz}, 10 \mathrm{c}$ $\mathrm{Oz}, 25 \mathrm{c} / 1 / 2 \mathrm{lb}$.

\section{MANGEL WURZEL BEETS FOR STOCK UR CATTLE FEEDING.}

If ordered by mail, add sc. per lb.

Golden Tankard. Contains more sugar and less water than anr other kind eultirated. Deep yellow in color and exceedingly productice. 5c oz, $10 \mathrm{c} 1 / 1 \mathrm{lb}, 30 \mathrm{c} \mathrm{lb}$.

Giant Long Red. Roots of immense size, rerT smooth and regular, and fine for stock. Adrertised under varied and high-sounding names, such as Improved Mammoth, Colossal, Prize, etc. $5 \mathrm{c} \mathrm{oz}, 10 \mathrm{c} \frac{1}{1 / 1} \mathrm{lb}, 30 \mathrm{c} \mathrm{lb}$.

Improved White Sugar. Attains a rerv large size, grows considerably above the ground, and is rery fine for stock feeding. $5 \mathrm{c} \mathrm{oz}, 10 \mathrm{c} 1 / 1 \mathrm{lb}, 30 \mathrm{c} \mathrm{lb}$. 


\section{CABBAGE.}

One ounce of seed will produce 3500 plants; five ounces for an acre.

Large quantities of Imported Cabbage Seed are offered as American at low prices. Our experience is that it is often disappointing in results.

\section{FIRST EARLY CABBAGES.}

Selected Early Jersey Wakefield. Leading early variety, conical heads, solid and compact, outer leaves thick and heavy; also winters well. $5 \mathrm{c} 1 / 4 \mathrm{oz}, 20 \mathrm{coz}$.

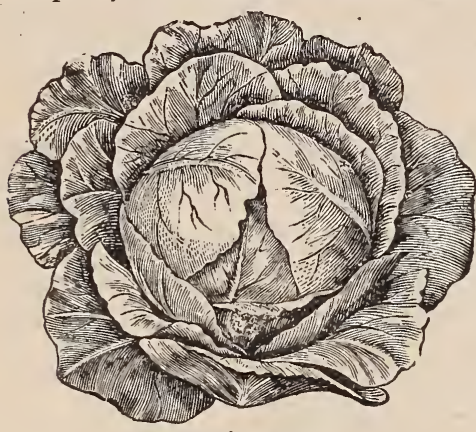

New Early Spring.

Charleston, or Large Wakefield. Large and solid heads, weighing 15 to 18 pounds, not so pointed as Jersey Wakefield, nor as liable to burst when maturing, but a week later. Solidity and long keeping qualities make it very popular. $5 \mathrm{c} 1 / 4$ $\mathrm{oz}, 20 \mathrm{c} \mathrm{oz}$.

Early Dwarf Flat Dutch. Best early flathead variety, very solid heads, broad and romid, flat on top, tender and fine grained. $5 \mathrm{c} 1 / 4 \mathrm{oz}, 20 \mathrm{c} \mathrm{oz}$.

Early Winnigstadt. Distinct early sort and one of the best for general cultivation; very hardy, little subject to wet or drouth, insects or disease; sure header, uniform size. conical, and very solid; goud for general cultivation. $5 \mathrm{c} 1 / 4 \mathrm{oz}, 20 \mathrm{coz}$.

New Early Spring. An extra early, round flat head, coming as early as Wakefield, and yielding a third mole. $5 \mathrm{c} 1 / 4 \mathrm{oz}, 20 \mathrm{coz}$.

\section{SECOND EARLY OR SUMMER CABBAGES.}

Henderson's Early Summer. Very early, large heads, flat or slightly conical, and keeps 'ong without bursting. Valuable for both fanily and market. 5c 1/4 oz, 20c oz.

Surehead. 'Large round flat heads like the Flat Dutch, a very sure header, unifor'm and firm. $5 \mathrm{c} 1 / 4 \mathrm{oz}, 20 \mathrm{c} \mathrm{oz}$.

All Seasons. Bright blue-green in color and does not burst, heads very large, solid, round and flattened, and a good keeper. $5 \mathrm{c} 1 / 4 \mathrm{oz}, 20 \mathrm{c} \mathrm{oz}$.

Succession. Intermediate betreen Early and Late Flat Dutch, and nearly twice as large as Farly Summer. $5 \mathrm{c} 1 / 1 / 10 z, 20 \mathrm{coz}$.

Hollander, or Improved Danish Ballhead. (See cut.) Is hardest heading:variety known, remarkable for great weight and long keeping qualities, and commanding a higher price in the market than any other variety. Heads of medium size, with but few outer leaves, admitting close planting; exceedingly fine, hardest of all, tender, crisp and solid, with no waste of heart, and will average six pounds. $5 \mathrm{c}$ per $1 / 4 \mathrm{oz}, 20 \mathrm{coz}$.

Large Late Flat Dutch. For a large, heavy. hard and smooth-leaved, late ripening cabbage, no strain is superior and few equal. The leares are feathered to the stalk, slightly fluted or twisted on the outer edges, clear green with a gray or ashy shade, and when frost strikes the outer leaves they often become dashed on the margin with faint tones of red and purple. Head thick, broad, solid, and slightly rounded on top. $5 \mathrm{c} 1 / 4 \mathrm{oz}, 15 \mathrm{c} \mathrm{oz}$.

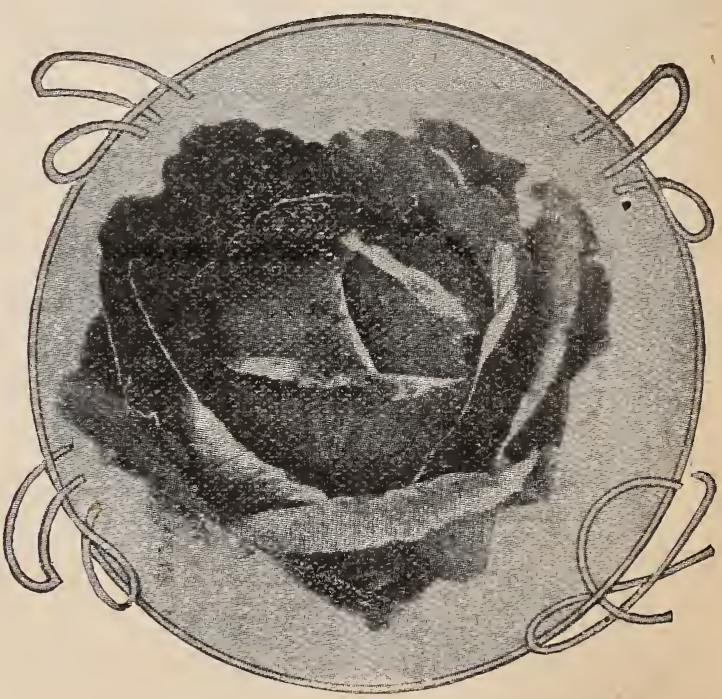

Hollande: 
Autumn King, or World Beater. Grows to an enormous size, making heads as solid as a rock, comes uniformly true to type, and can be relied upon to produce more rveight from the same space of ground than most late sorts. $5 \mathrm{c} \frac{1}{4} \mathrm{oz}, 15 \mathrm{c} \mathrm{oz}$.

Louisville Drumhead. Grown largely by gardeners in the southwest, stands hot weather better than most other sorts, and is a sure cropper. $5 \mathrm{c} 1 / 4 \mathrm{oz}, 15 \mathrm{c} \mathrm{oz}$.

Improved American Savoy. Decidedly the peer of all Savoys, either for market or kitchen gardens. Large and very solid heads, fine and delicate flavor, showing leaves beautifully curled and crimped, of dark rich green color. $5 \frac{1}{4} \mathrm{oz}, 15 \mathrm{c} \mathrm{oz}$.

Mammoth Red Rock. Largest, best and most reliable red cabbage, large head round, very solid and deep red in color. $5 \mathrm{c} \frac{1}{4} \mathrm{oz}, 15 \mathrm{c} \mathrm{oz}$.

\section{CELERY.}

One ounce of seed will produce 4,000 to 5,000 plants.

White Plume. Stalks, inner leares and heart are white, so that tying up or simply drawing up the soil completes the work of blanching. Equal to the very best sortsearly, handsome, easily grown, profitable for early market. $5 \mathrm{c} \frac{1}{4} \mathrm{oz}, 10 \mathrm{c} 1 / 2 \mathrm{oz}, 20 \mathrm{c} \mathrm{oz}$.

Golden Yellow Large Solid, or Golden Self=Blanching. (See cut.) Large heart, solid, excellent keeper, and raluable to the market gardener as well as to the amateur. $5 \mathrm{c} 1 / 4 \mathrm{oz}, 10 \mathrm{c} 1 / 2 \mathrm{oz}, 20 \mathrm{c} \mathrm{oz}$.

Pink Plume. Most delicious in flaror, (risp and nutty, the first and last celery fit to use, so brittle that stalks held in the hand will almost break of their own weight. Solid and succulent stalks of ivory white suffused with dainty pink. $5 \mathrm{c} \frac{1}{4} \mathrm{oz}, 10 \mathrm{c} \frac{1}{2} \mathrm{oz}, 20 \mathrm{coz}$.

Giant Pascal. A superior sort, stalks reìy large, thick, solid, crisp and of rich and nutty flaror, which is retained a long time after being marketed. Golden yellow heart and very meaty. $5 \mathrm{c} \frac{1}{4} \mathrm{oz}, 10 \mathrm{c} \frac{1}{2} \mathrm{oz}, 20 \mathrm{coz}$.

Crawford's Half Dwarf. A yellowish white when blanched, and possessing the nutty flavor peculiar to the dwarf kinds. $5 \mathrm{c} 1 / 4 \mathrm{Oz}, 10 \mathrm{c} \frac{1}{2} \mathrm{Oz}, 20 \mathrm{c} \mathrm{oz}$.

Dwarf Golden Heart. Distinct rariety, sturdy habit, excellent keeper, of fine nutty flavor, desirable. $5 \mathrm{c} 1 / 4 \mathrm{oz}, 10 \mathrm{c} \frac{1}{2} \mathrm{oz}, 20 \mathrm{c} \mathrm{oz}$.

Dwarf White Solid, or Kalamazoo. Very solid, crisp eating, and most delicious rariety, which has made Michigan's product famous. $5 \mathrm{c} 1 / 4 \mathrm{oz}, 10 \mathrm{c} \frac{1}{2} \mathrm{oz}, 20 \mathrm{c} \mathrm{oz}$.

Giant White Solid. Best large white solid celery, of very quick growth and stiff, close habit, stalk remarkably solid, with a fine crisp flavor. $5 \mathrm{e} \frac{1 / 4}{\mathrm{oz}}, 10 \mathrm{e} \frac{1}{2} \mathrm{oz}, 20 \mathrm{e} \mathrm{oz}$.

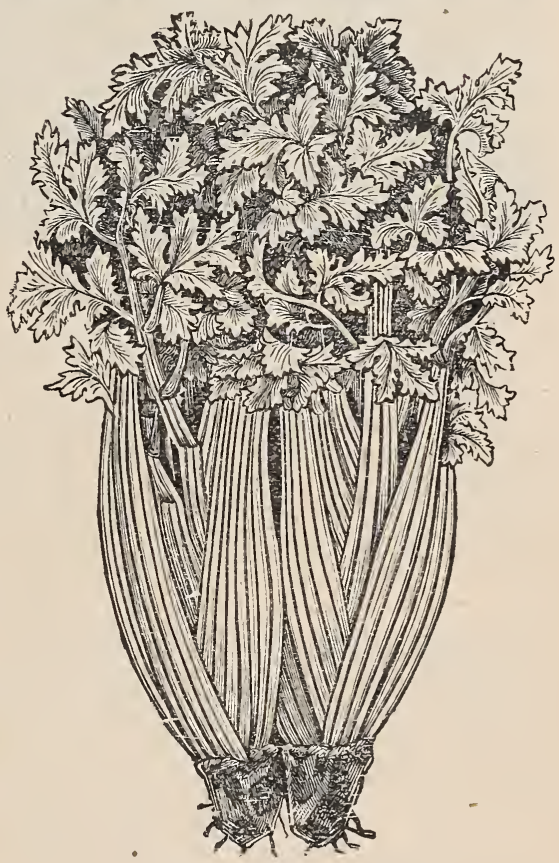

Golden Yellow.

Boston Market. A rigorous grower, of medium height, very early and an excellent keeper; rery solid, white, and of rather loose habit. $5 \mathrm{c} 1 / 4 \mathrm{oz}, 1, \mathrm{c} 1 / 2 \mathrm{oz}, 20 \mathrm{e} \mathrm{oz}$.

Celeraic. (Turnip-rooted.) Large Prague. The roots make most delicious salad when cooked and sliced and used with vinegar and oil. $5 \mathrm{c} 1 / 4 \mathrm{oz}, 10 \mathrm{c} \frac{1}{2} \mathrm{oz}, 15 \mathrm{coz}$.

\section{CORN SALAD OR FETTICUS.}

Oné ounce for twenty feet square; six pounds to the acre.

Large Seeded. Sown in the spring in drills one foot apart, it will mature in six to eight weeks. For use in winter or early spring, sow in Aug'ust or September, and corer with straw on winter's approach, the same as spinach. $5 \mathrm{c} 1 / 2 \mathrm{oz}, 30 \mathrm{c} 1 / \mathrm{lb}, 75 \mathrm{clb}$.

\section{GARDEN HERBS.}

Summer Savory, Saffron, Sage, Rosemary, Thyme, Caraway, Majorum and Balm. No kitchen garden is complete without them. 5c each per packet. 


\section{CORN-SWEET.}

One quart will plant 200 hills; eight to ten quarts for an acre in hills. If by mail arld $8 \mathrm{c}$. pint and $15 \mathrm{c}$. qt.

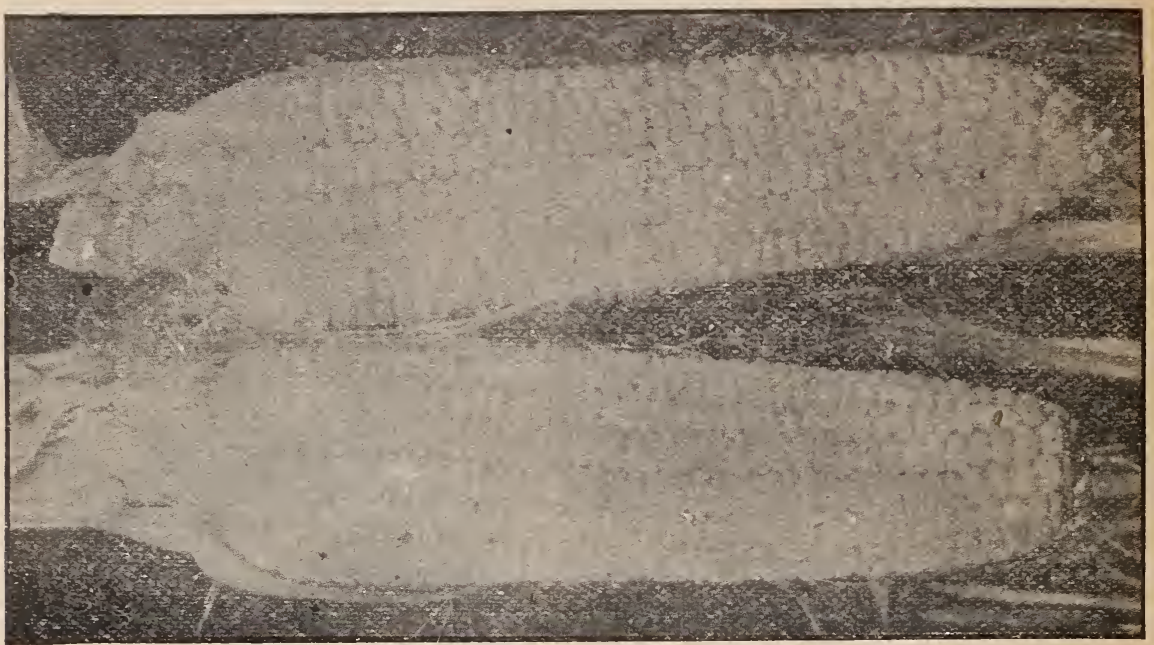

FIRST EARLY VARIETIES.

Mammoth White Cory. Decided improrement orer the original Cort, and largest and best extra early. Stalks bear two or more large fine-shaped ears, twelre-rowed, corered with large, broad, white grains of good quality; 70 days. $5 \mathrm{c} 1 / 2 \mathrm{pint}, 8 \mathrm{c}$ t, $15 \mathrm{c} \mathrm{qt}$.

Extra Early Adams. Tery early, but more of the quality of field than sweet corn. Ready for the table sixtr dars after germination, no suckers, few tassels, short stalk, bearing a single, very full, short, many-rowed ear. 5c $\frac{1}{2}$ pint, $8 \mathrm{c}$ pint, $15 \mathrm{c}$ quart.

Ford's Early. Surpasses all other early sweet corn in quality, and ready for the table sixty-eight days from germination; ears six to eight inches long, eight-rowed; deep and large kernel; stalk about fire feet, and usually two ears. $5 \mathrm{c} \frac{1}{2}$ pint, 8c pint, $15 \mathrm{c}$ qt.

\section{MEDIUM AND SECOND EARLY.}

Shaker's Early. Splendid market sort, large ear's, stalks six feet high in gooà soil, usually bearing two large ears of most delicious flaror. $5 \mathrm{c} \frac{1}{2} \mathrm{pint}, 10 \mathrm{c}$ pint, $15 \mathrm{c}$ quart.

Eight Row, or Early Sugar. Ears long and slender, grain white, tender, sugary, and comes in about sixty-eight dars. $5 \mathrm{c} \frac{1}{2}$ pint, $8 \mathrm{e}$ pint, $15 \mathrm{c}$ quart.

Early Mammoth. Ripens two weeks earlier than Late Mammoth, smaller ears, but of good market size; serenty days. $5 \mathrm{c} 1 / 2$ pint, $8 \mathrm{c}$ pint, $15 \mathrm{c}$ quart.

\section{LATE OR MAIN CROP YARIETIES.}

Stowell's Evergreen. For family use, market or canning it is unexcelled, a heary yielder, tender and sugary; 70 days. $5 \mathrm{c} 1 / 2$ pint, $8 \mathrm{c}$ pint, $15 \mathrm{c}$ quart.

Country Gentieman. Cob rery small, and the deep, irregular kernals are sweetest and most tender of all; sometimes called Shoe-peg; 70 dass. $5 \mathrm{c} \frac{1}{2} \mathrm{pint}, 8 \mathrm{c}$ pint, $15 \mathrm{c} \mathrm{qt}$.

old Colony. An old rariety hard to beat, ripening ahead of Stowell's Evergreen; tall stalks, usually two large ears, sixteen rows; 75 dars. $5 \mathrm{c} \frac{1}{2} \mathrm{pint}, 8 \mathrm{c}$ pint, $15 \mathrm{c}$ quart.

Zig=zag Evergreen. Best large-eared late corn, very productice, yielding two to four ears to the stalk; 78 days. $5 \mathrm{c} \frac{1}{2} / \mathrm{pint}, 8 \mathrm{c}$ pint, $15 \mathrm{c}$ quart.

Mammoth Late Sugar. Green ears weigh two or three pounds, the sweetest and largest of all, and great for fodder. $5 \mathrm{c} \frac{1}{2} \mathrm{pint}, 8 \mathrm{c}$ pint, $15 \mathrm{c}$ quart.

\section{POP CORN.}

Rice. Tery handsome variets, with short ears, pointed and resembling rice, white in color and rery prolific. 5e $1 / 1 /$ pint, $8 \mathrm{c} 1 / 2$ pint, $15 \mathrm{c}$ pint.

Queen's Golden. Stalks five to six feet high, bearing two or three large ears, pops creamy white, and a single kernal often expands an inch. $5 \mathrm{c} 1 / 1 / \mathrm{pint}$, $8 \mathrm{c} 1 / 2$ pint, $15 \mathrm{c}$ pint.

Silver Lace, or Pearl. Exceedingly handsome variety of smooth white corn, a fine popper and heary producer. $5 \mathrm{c} 1 / 4$ pint, $8 \mathrm{c} \frac{1}{2}$ pint, $15 \mathrm{c}$ pint. 


\section{CUCUMBERS.}

One ounce will plant one hundred hills; two pounds to the acre.

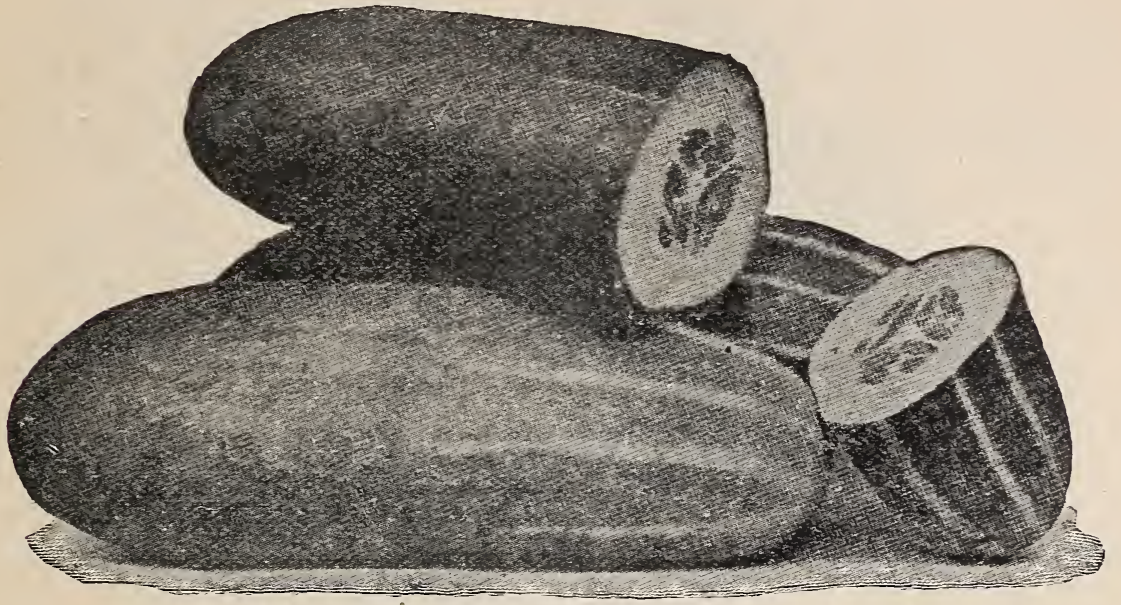

Arlington, or Extra Early White Spine.

Arlington, or Extra Early White Spine. (See cut.) Every market gardener knows the value of a well selected and fixed strain of extra early cucumbers, especially for forcing purposes. This is an excellent rariety for slicing, and makes a choice pickle, straight and smooth. It is also a prolific bearer, and keeps green much longer than the yellow varieties. $5 \mathrm{c} 1 / 4 \mathrm{oz}, 15 \mathrm{c} \mathrm{oz}, 50 \mathrm{c} \frac{1}{1 / \mathrm{lb}}$.

Early Green Cluster. Tigorous vines, producing the crop in clusters near the root. Frnit short, holding full size to each end, dark green but paler at the blossom end. Good for table use, but not adapted to pickling. $5 \mathrm{c} 1 / 4 \mathrm{oz}, 15 \mathrm{c} \mathrm{oz}, 50 \mathrm{c} 1 / 4 \mathrm{lb}$.

Jersey Pickling. Most popular sort for pickling; very productive, slender, long and cylindrical in shape. $5 \mathrm{c} 1 / 4 \mathrm{oz}, 15 \mathrm{c} \mathrm{oz}, 50 \mathrm{c} 1 / 4 \mathrm{lb}$.

Early Frame or Short Green. A deservedly popular variety of medium size for early use. $5 \mathrm{c} 1 / 4 \mathrm{oz}, 15 \mathrm{coz}, 50 \mathrm{c} 1 / 4 \mathrm{lb}$.

Extra Long Evergreen, or Bismarck. A cross between Long Green and White Spine; dark color, slender, early, strong, vigorous growth, withstanding drouth and very productive, bearing abundantly until frost. A perfect pickle sort, and the firm and crisp fruits are also excellent for slicing. $5 \mathrm{c} \frac{1}{4} \mathrm{oz}, 15 \mathrm{c} \mathrm{oz}, 50 \mathrm{c} 1 / 4 \mathrm{lb}$.

Improved Long Green. Well known rariets, about one foot in length, dark green, firm and crisp. The young fruit makes one of the best pickles, and when ripe is best of any for street pickles. $5 \mathrm{c} 1 / 4 \mathrm{oz}, 15 \mathrm{c} \mathrm{oz}, 50 \mathrm{c} 1 / 4 \mathrm{lb}$.

New Japanese Climbing. Of climbing habit; fruit straight and from 12 to 16 inches in length, thick, tender, delicate flaror, flesh pure white, skin dark green turning to brown, and netted when ripe. The cucumbersare of good quality, and when roung make rerr fine pickles. $10 \mathrm{c} 1 / 4 \mathrm{oz}, 15 \mathrm{c} \mathrm{oz}, 50 \mathrm{c} 1 / 4 \mathrm{lb}$.

Gherkin. Bur cucumber, used entirely for pickling. Vers small, oral, prickls, and should always be picked when young and tender. $5 \mathrm{c} \frac{1}{2} \mathrm{oz}, 10 \mathrm{coz}, 25 \mathrm{c} \frac{1}{4} \mathrm{lb}$.

\section{CAULIFLOWER.}

One ounce of seed will produce fifteen hundred plants.

Early Snowball. (See cut.) The outer leares are short, so that the plants mar be set from eighteen to twenty inches apart. Under favorable conditions nearly every plant will make a solid and fine head of good size. It is of dwarf habit, and raluable for both early and late crops. $15 \mathrm{c}$ per $1-16 \mathrm{oz}, 25 \mathrm{c} 1 / 8 \mathrm{oz}, \$ 2.00 \mathrm{oz}$.

\section{CRESS OR PEPPER GRASS.}

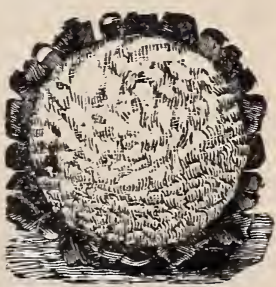

Fine Curled. Tery superior variety, and will bear cutting several times. It gives pungent relish to lettuce and other salad plants. $5 \mathrm{c} 1 / 2 \mathrm{oz}, 10 \mathrm{c} \mathrm{oz}$. 


\section{CARROTS.}

One ounce will sow one hundred feet of drill; three to four pounds to an acre.

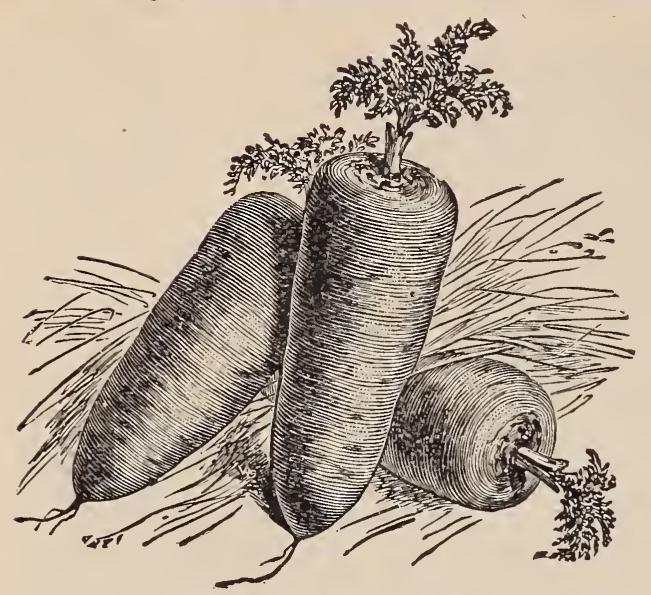

Danvers Half-Long Orange.

Danvers Half=Long Orange. (See cut.) First-class variety, flesh dark orange; sinooth, handsome roots of medium length, tapering uniformly to a blunt point; flesh sweet, crisp and tender; very productive, and a great favorite with market gardeners. 5 . $1 / 2 \mathrm{oz}, 10 \mathrm{e} \mathrm{oz}, 25 \mathrm{c} 1 / 1 \mathrm{lb}$.

Early Scarlet Horn. Not large. but a farorite for early crop. Small. tops, stump-rooted, orange flesh and fine grain. $5 \mathrm{c} \frac{1}{2} \mathrm{oz}, 10 \mathrm{c} \mathrm{oz}, 25 \mathrm{c} 1 / 4 \mathrm{lb}$.

Chantenay Stump=Rooted. Very early and productire, alwayssmooth. orange red, flesh crisp and tender. 5c $1 / 2 \mathrm{oz}, 10 \mathrm{c} \mathrm{oz}, 25 \mathrm{c} 1 / 4 \mathrm{lb}$.

Improved Long Orange. An old standard and very popular variety, growing to large size, some specimens averaging trelve inches in length; one of the best varieties for stock feeding. $5 \mathrm{c} \frac{1}{2} \mathrm{oz}, 10 \mathrm{c} \mathrm{oz}, 25 \mathrm{c} \frac{1 / 4}{1 b}$.

\section{EGG PLANT.}

One ounce to two thousand plants.

New York Improved. Leading market variety everywhere. Robust plants, and leaves and stems are spineless. Egg Plant is very tender, and the seed requires strong heat to regetate. On this account, amateurs often fail with it. $5 \mathrm{c}$ packet, $40 \mathrm{coz}$.

\section{ENDIVE.}

One ounce of seed to 150 feet of row. When two or three inches high, transplant or thin out to one foot apart. When nearly full grown, tie up the leaves to blanch when quite dry, for they will rot if wet.

White Curled. (See cut.) By far the most beautiful variety; plant moderately dense, leaves coarser than the GreenCurled, but the mid-rib is yellow, and the leaves frequently almost white, so that the plants are very attractive and bring the highest prices on the market. $5 \mathrm{c} 1 / 4$ $\mathrm{oz}, 20 \mathrm{c} \mathrm{oz}, 50 \mathrm{c} \frac{1}{4} \mathrm{lb}$.

Broad Leaved Batavian. It forms large heads of broad thick leaves, which are used for flavoring soups and stews; if blanched the inner leaves make very fine salad. $5 \mathrm{c} 1 / 4 \mathrm{oz}, 20 \mathrm{c} \mathrm{oz}, 70 \mathrm{c} 1 / 4 \mathrm{lb}$.

Green Curled. Very hardy, but one of the most crisp and tender sorts. $5 c \frac{1}{4}$ $\mathrm{oz}, 15 \mathrm{c} \mathrm{oz}, 50 \mathrm{c} 1 / 4 \mathrm{lb}$.

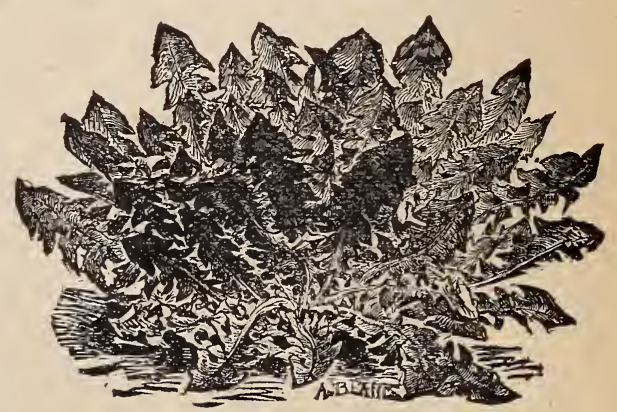

White Curled Endive.

\section{KALE OR BORECOLE.}

Tall Green Curled Scotch. This is the variety most in use, needing no protection in winter. $5 \mathrm{c} 1 / 2 \mathrm{oz}, 10 \mathrm{c} \mathrm{oz}, 15 \mathrm{c} 1 / 4 \mathrm{lb}$,

Dwarf Curled Scotch, or German Greens. Plant low and compact, with leaves curled, cut and crimped until plant resembles a huge bunch of moss. $5 \mathrm{c} 1 / 2 \mathrm{oz}, 15 \mathrm{c} 1 / 4 \mathrm{lb}$.

Siberian. Sometimes called Sprouts or German Greens. Very large leares, comparatively plain in the center, but coarsely cut and frilled on the edge. $5 \mathrm{c} \frac{1}{2} \mathrm{oz}, 15 \mathrm{c} 1 / 4 \mathrm{lb}$.

KOHL RAB!-Early White Vienna. Favorite garden vegetable in Europe, where it is extensively grown for feeding cattle, as well as table use. Known as the TurnipRooted Cabbage, requires the same cultivation, flesh is tender and white, with a handsome, firm and glossy bulb. $5 \mathrm{c} 1 / 4 \mathrm{oz}, 20 \mathrm{coz}$.

LEEK-American Flag. Large, hardy and excellent quality. One ounce will sow one hundred feet of drill and produce one thousand plants. $5 \mathrm{c} \frac{1 / 4}{4} \mathrm{oz}, 15 \mathrm{coz}$. 


\section{LETTUCE.}

One-half ounce will sow one hundred feet of drill.

\section{CABBAGE OR HEADING VARIETIES.}

California Cream Butter. (See cut.) Black seed. Summer rariety, with creamy rellow leaves, rich and buttery to the taste, heads of good size, round, solid, and slow to go to seed. $5 \mathrm{c} 1 / 8 \mathrm{oz}, 25 \mathrm{c} 1 / \mathrm{l} \mathrm{lb}$.

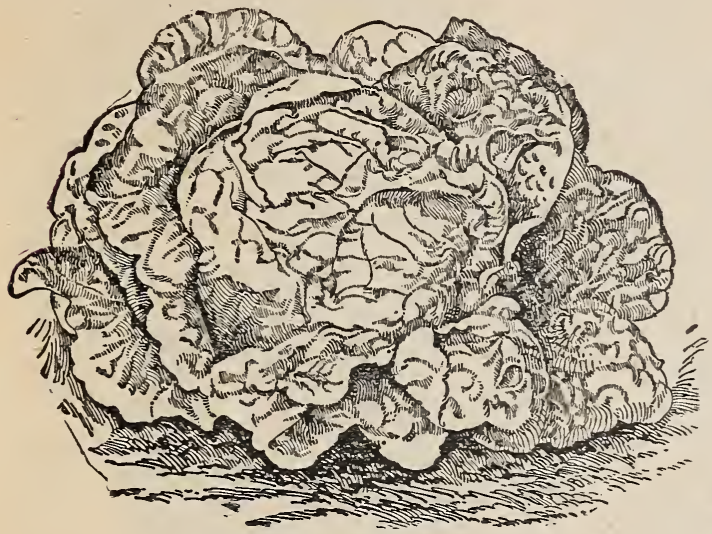

California Cream Butter.

Maximum, or Immensity. The newrest Lettuce offered, a wonderful resister of heat, and remains a long time, even in the hottest weather, without going: to seed; green outside and rellow in the center; one of the largest and most solid of head Lettuces, its quality is of the best, and gardeners should give it a thorough trial. $10 \mathrm{c} \frac{1}{2} \mathrm{oz}$, 40 c $1 / 4 \mathrm{lb}$.

Early Prizehead. A mammoth plant, in which even the outer leares are crisp and tender, remaining so throughout the season. Slow to run to seed, of superbflavor and very hardy, one of the best for family use. White seed. $5 \mathrm{c} 1 / 2 \mathrm{oz}, 10 \mathrm{c} \mathrm{oz}$ $25 \mathrm{c} \frac{1}{4} \mathrm{lb}$.

Improved Hanson. White seed. No more reliable standard summer lettuce for outdoor cultivation. Heads grow to a remarkable size, very solid, bright green outer leares, while the inner head presents a white appearance, as though blanched. Tender, crisp, free from any unpleasant bitter taste, rery slow to seed. $5 \frac{1}{2} \mathrm{oz}, 10 \mathrm{c} \mathrm{oz}, 25 \mathrm{c} 1 / 4 \mathrm{lb}$.

Salamander, or Satisfaction. Black seed. Forms large, solid, compact heads, and resists summer heat; leaves long, smooth, thick and very tender, the inner hea.d blanching almost white; excellent for spring, summer and fall. $5 \mathrm{c} 1 / 2 \mathrm{oz}, 10 \mathrm{c} \mathrm{oz}, 25 \mathrm{c} 1 / 4 \mathrm{lb}$.

New Iceberg. White seed. Quick growing; hard and handsome heads, tender and true-no handsomer or more solid cabbage variety in cultivation. Large, curly outside leares of light, bright green, solid heads. $5 \mathrm{c} \frac{1}{2} \mathrm{oz}, 10 \mathrm{c} \mathrm{oz}, 25 \mathrm{c} 1 / 1 \mathrm{lb}$.

Brown Dutch. Black seed. Old sort, noted for its hardiness; large, thick green leaves, tinged with brown, always forms large, solid head. $5 \mathrm{c} \frac{1}{2} \mathrm{oz}, 10 \mathrm{c} \mathrm{oz}, 25 \mathrm{c} 1 / 4 \mathrm{lb}$.

\section{CURLED OR LOOSE=LEAVED VARIETIES.}

Black=Seeded Simpson. (See cut.) Most popular sort, one of the best for under glass and early out-door planting. Large, loose heads, outer leaves a light yellowish green, inner leares blanched to almost white, resisting heat and remaining a long time in an edible condition. $5 \mathrm{c} / \frac{1}{2} \mathrm{Oz}, 10 \mathrm{c} \mathrm{oz}, 25 \mathrm{c} 1 / 4 \mathrm{lb}$.

Grand Rapids Forcing. Black seed. Good for out-doors as well as under glass, large and beautiful leares, rery crisp and tender. Tery heavy producer, twents to thirty pounds having been taken from a common sash. $5 \mathrm{c} 1 / 2 \mathrm{oz}, 10 \mathrm{c} \mathrm{oz}, 25 \mathrm{c}$ $1 / 4 \mathrm{lb}$.

Simpson Early Curled. White seed. (Silesia.) Compact mass of leares, large and broad, crimped and blistered, light green in color. Needs bottom heat for forcing, and is recommended for cold frames, but is extensively grown in the open. $5 \mathrm{c} \frac{1}{2} \mathrm{oz}, 10 \mathrm{c} \mathrm{oz}, 25 \mathrm{c} \frac{1}{4} \mathrm{lb}$.

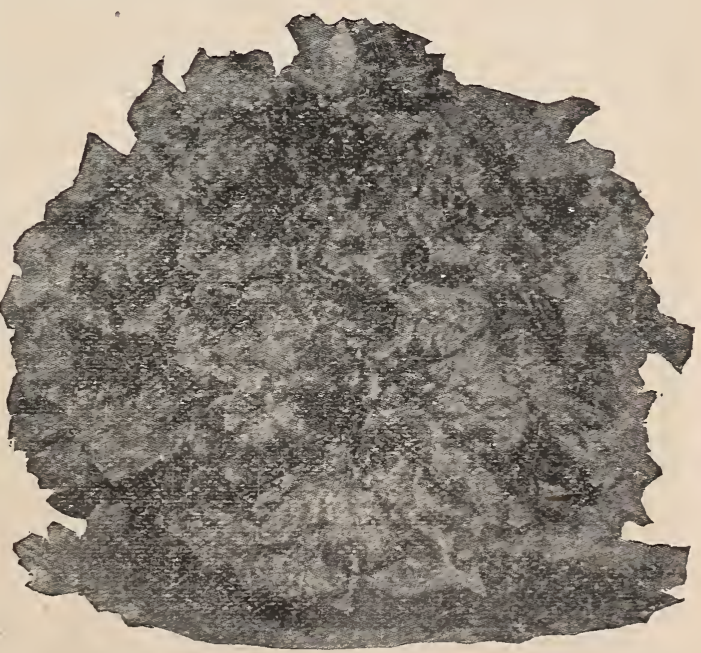

Black-Seeded Simpson. 


\section{MELONS-WATER.}

One ounce of seed for thirty hills; four to five pounds to the acre.

Sweet Heart. (See cut.) Early, large, handsome, heary, good shipper, long keeper, skin and flesh of splendid color; rine vigorous and productire, fruit large. oral, very heary, uniformly mottled, and rery light green; rind thin but firm, flesh bright red, firm and solid, but very tender, sweet and melting. The fruit remains in condition for use longer than any other sort; dark gray seeds. $5 \mathrm{c} \frac{1}{2} \mathrm{oz}, 10 \mathrm{c} \mathrm{oz}, 50 \mathrm{c} \mathrm{lb}$.

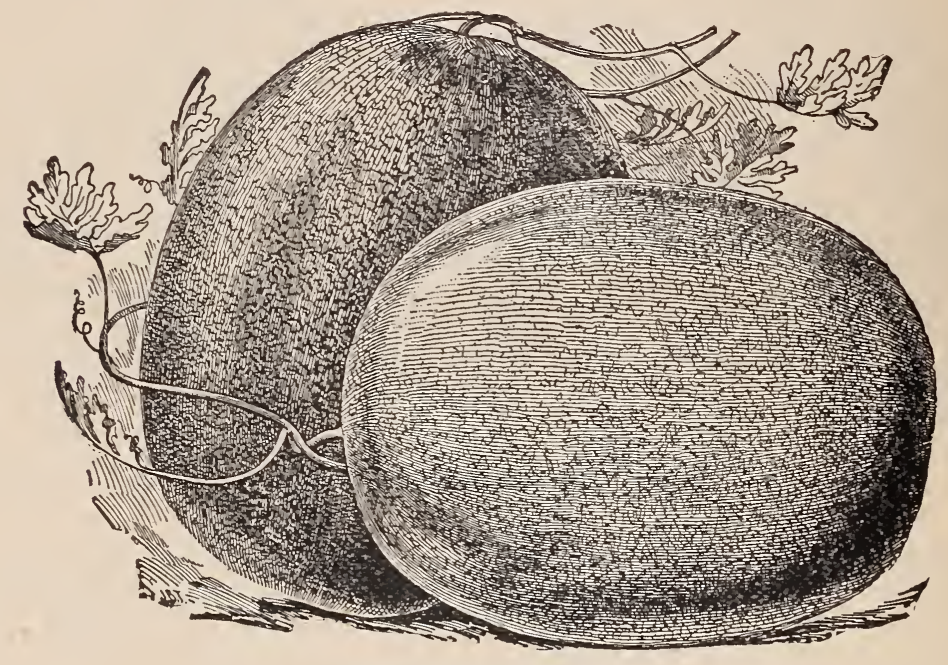

Sweet Heart Water Melon.

Fordhook Early. The earliest large-fruited melon in cultivation; fruits are of good size, rather short and blocky in form, with large diameter; skin dark green, occasionally with stripes of lighter green; flesh bright red, crisp, sweet, and of splendid quality; rind quite thin, but skin tough, and it makes a splendid variety for early shipping as well as the home market. $5 \mathrm{c} \frac{1}{2} \mathrm{oz}, 10 \mathrm{c} \mathrm{oz}, 50 \mathrm{c} \mathrm{lb}$.

Kleckley Sweets. Vines strong, vigorous, and fruits uniformly large size, oblong in form, eighteen to twenty inches long; ten to twelve in diameter, tapering ends; skin rich dark green, flesh bright scarlet, ripening close to the rind, and crisp, sugary and melting. $5 \mathrm{c} 1 / 2 \mathrm{oz}, 10 \mathrm{c} \mathrm{oz}, 75 \mathrm{c} \mathrm{lb}$.

Duke Jones. One of the largest and most productive; early, solid red meat, fine flavor, and very hears yielder. Suitable for home gardens as well as shipping. $5 \mathrm{c} 1 / 2 \mathrm{oz}$, $10 \mathrm{c} \mathrm{oz}, 50 \mathrm{c} \mathrm{lb}$.

Dark Iceing, or Ice Rind. Round form, white-seeded, and can scarcely be praised too highly for solidity, thin rind, and rich, luscious, sugary flavor; fruit large, nearly round, dark green, distinctly mottled, flesh very rich and bright red. Abundant juice of rich deep color, flowing so freely as to be available as a drink. $5 \mathrm{c} 1 / 2 \mathrm{oz}, 10 \mathrm{c} \mathrm{oz}, 50 \mathrm{c} \mathrm{lb}$.

Kolb's Gem. Rind rery thin and tough, stands shipping well, fruit of the largest size, round or slightly oral, marked with irregular and mottled stripes of light and dark green, flesh bright red, solid, sweet and tender. $5 \mathrm{c} 1 / 2 \mathrm{oz}, 10 \mathrm{c} \mathrm{oz}, 50 \mathrm{c} \mathrm{lb}$.

Dixie. Similar to Kolb's Gem, larger, ten days earlier, striped, more productive, six to eight large melons on a rine not being uncommon. $5 \mathrm{c} \frac{1}{2} \mathrm{oz}, 10 \mathrm{c} \mathrm{oz}, 50 \mathrm{c} \mathrm{lb}$.

Round Light Iceing. Fruit of medium size, very light green, mottled with slightly darker green, flesh bright, light red, and very sweet and tender-considered the best of all melons by many. $5 \mathrm{c} \frac{1}{2} \mathrm{oz}, 10 \mathrm{c} \mathrm{oz}, 50 \mathrm{c} \mathrm{lb}$.

Mountain Sweet. Large oval variety, green rind, scarlet flesh and quite solid to the center, very sweet and delicious-an old standard sort and one of the best for the home garden. $5 \mathrm{c} 1 / 2 \mathrm{oz}, 10 \mathrm{c} \mathrm{oz}, 60 \mathrm{c} \mathrm{lb}$.

Ice Cream, or Peerless. Excellent for home use, medium size, oblong, light green skin, white seeds, with very sweet and melting crimson flesh. $5 \mathrm{c} 1 / 2 \mathrm{oz}, 10 \mathrm{c} \mathrm{oz}, 60 \mathrm{c} \mathrm{lb}$.

Gipsy, or Georgia Rattlesnake. One of the earliest of the large melons that do particularly well in the south. $5 \mathrm{c} \frac{1}{2} \mathrm{oz}, 10 \mathrm{c} \mathrm{oz}, 90 \mathrm{c} \mathrm{lb}$. 
MELONS-MUSK.

Dne ounce will plant eighty hills; two pounds of seed to the acre.

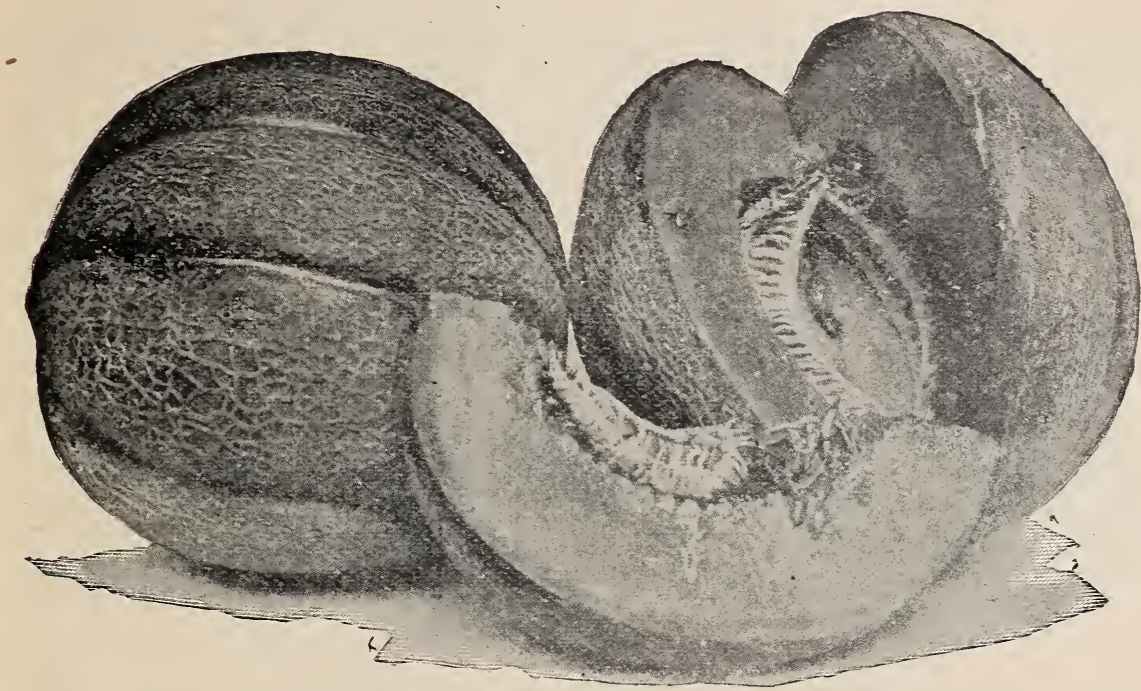

Tip Top Musk Melon.

Tip Top. (See cut.) In qualits, appearance and productireness all that the name implies, and should be planted by erery gardener. Every melon produced, whether big or little, early or late, is a good one-sweet, juicr, finest flaror, firm-fleshed and eatable to the outside coating; large size, nearly round, erenly ribbed and moderately netted. The most productive melon known. One customer reports serentr-two large and magnificent melons from two hills. $5 \mathrm{c} 1 / 2 \mathrm{oz}, 10 \mathrm{c} \mathrm{oz}, 25 \mathrm{c} 1 / 4 \mathrm{lb}, 60 \mathrm{clb}$.

Petoskey, or Paul Rose. Combines all the good qualities of the Netted Gem and Osage, from which it originated. Fruit is oral, about fire inches in diameter, flesh firm and rich orange red color, rery sweet, high flarored and uniformly good. Superb for market and shipping, just right for hotel and table use. $5 \mathrm{c} 1 / 2 \mathrm{oz}, 10 \mathrm{c} \mathrm{oz}, 25 \mathrm{c} 1 / \mathrm{lb}, 60 \mathrm{e} \mathrm{lb}$.

Rocky Ford. This new rare gem from Colorado has become one of the most popular of small or basket melons. Fruit is oral, slightls ribbed, densels corered with coarse netting. Flesh thick, green, rery street and high flarored, and the fruit is "ronderfully uniform in shape and quality. $5 \mathrm{c} \frac{1}{2} \mathrm{oz}, 10 \mathrm{coz}, 25 \mathrm{c} \frac{1}{4} \mathrm{lb}, 60 \mathrm{c} \mathrm{lb}$.

Oval Netted Gem. Remarkably uniform, weighing one and a quarter to one and a half pounds; flesh thick-meated, light green in color, uniformly of fine and luscious flavor; skin green, regularly ribbed and thickly netted; early. $5 \mathrm{c} 1 / 2 \mathrm{oz}, 10 \mathrm{c} \mathrm{oz}, 25 \mathrm{c} 1 / 4 \mathrm{lb}$.

New Early Hackensack. One of the rery best market melons, of large size and attractive appearance; very productire, excellent fla ror, and gтown in some sections to the exclusion of all others. $5 \mathrm{c} 1 / 2 \mathrm{oz}, 10 \mathrm{c} \mathrm{oz}, 20 \mathrm{c} 1 / 1 \mathrm{lb}, 60 \mathrm{clb}$.

Hackensack, or Turk's Cap. Fruit very large, flattened and globe-shaped, large ribs of irregular width, coarse flesh. sweet, finest fla ror. $5 \mathrm{c} \frac{1}{2} \mathrm{oz}, 10 \mathrm{c} \mathrm{oz}, 20 \mathrm{c} 1 / \mathrm{lb}, 60 \mathrm{c} \mathrm{lb}$.

Casaba, or Green Persian. One of the largest and best; fruit oral and long, a little pointed at each end; green flesh and very sweet. $5 \mathrm{c} 1 / 2 \mathrm{oz}, 10 \mathrm{c} \mathrm{oz}, 20 \mathrm{c} 1 / 4 \mathrm{lb}, 60 \mathrm{c} \mathrm{lb}$.

Small Green Nutmeg. Fruit of medium size, slightly ribbed and globular; skin dark green, corered with shallow netting, flesh thick and coarse. $5 \mathrm{c} 1 / 2 \mathrm{oz}, 10 \mathrm{c} \mathrm{oz}, 6(\mathrm{cclb}$.

Usage, or Miller's Cream. Flesh thick, deep salmon color and rery sweet-a most attractive sort for the market. $5 \mathrm{c} 1 / 2 \mathrm{oz}, 10 \mathrm{c} \mathrm{oz}, 20 \mathrm{c} 1 / 4 \mathrm{lb}, 60 \mathrm{clb}$.

Emerald Gem. Standard of excellence; fruit small to medium in size, globular or slightly flattened, netted and slightly ribbed; deep green skin, flesh deep salmon rellow; ripening close to the rind, and unsurpassed in flaror. $5 \mathrm{c} \frac{1}{2} \mathrm{oz}, 10 \mathrm{c} \mathrm{oz}, 60 \mathrm{clb}$.

Montreal Green. Size exceeds all other nutmeg's, weighing sometimes 30 pounds. very uniform shape, netted, green flesh, good quality. $5 \mathrm{e} 1 / 2 \mathrm{oz}, 10 \mathrm{c} \mathrm{oz}, 20 \mathrm{c} 1 / 4 \mathrm{oz}, 60 \mathrm{clb}$.

Banana. Eighteen to 24 inches in length, smooth, bright, rellow skin, flesh salmon red. $5 \mathrm{c} \frac{1 / 2}{2} \mathrm{oz}, 10 \mathrm{c} \mathrm{oz}, 20 \mathrm{c} 1 / 4 \mathrm{lb}, 75 \mathrm{c} \mathrm{lb}$.

MUSTARD-White. Stems succulent, sweet and pungent, best for salads and culinary purposes. One ounce to 75 feet of drill. $5 \mathrm{c} \mathrm{oz}, 10 \mathrm{c} 1 / 4 \mathrm{lb}, 30 \mathrm{c} 1 \mathrm{~b}$. 


\section{ONIONS.}

Oue ounce of seed to one hundred feet of drill; six pounds to the acre.

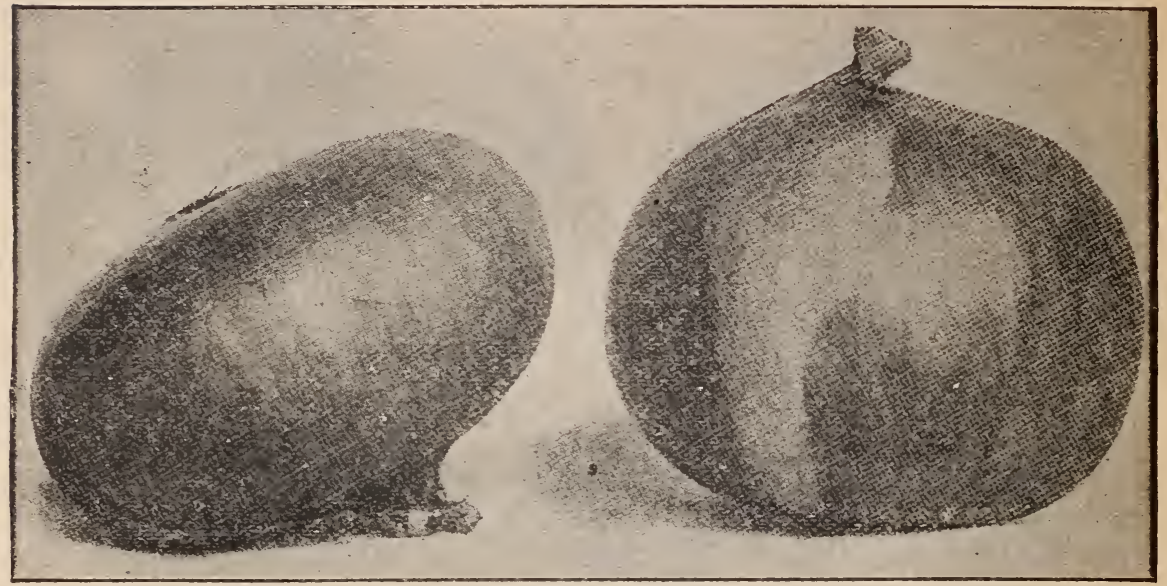

Red Wethersfield.

Danvers Yellow Globe.

Danvers Yellow Globe. (See cut.) Flesh white and comparatively mild in flavor, rery productive, a good keeper, and considered the best and most profitable market sort. $5 \mathrm{c} \frac{1}{4} \mathrm{oz}, 10 \mathrm{e} \frac{1}{2} \mathrm{oz}, 20 \mathrm{e} \mathrm{oz}, 40 \mathrm{e} \frac{1}{4} \mathrm{lb}$.

Yellow Danvers Flat. A splendid onion for market or home use. More flat than Globe Danrers, but considered equal in quality. $5 \mathrm{c} \frac{1}{4} \mathrm{oz}, 10 \mathrm{c} \frac{1}{2} \mathrm{oz}, 20 \mathrm{coz}, 40 \mathrm{c} \frac{1}{4} \mathrm{lb}$.

Large Red Wethersfield. (See cut.) Standard red rariety for large market crops. Large size, skin deep purplish red, form round and somewhat flat, flesh purplish white, moderately fine-grained, and of stronger flavor than other kinds; rery productive, best keeper, and most popular for general cultiration. Inclined to form large necks if grown on unsuitable soil. 5e 1/4 oz, $10 \mathrm{c} 1 / 2 \mathrm{oz}, 20 \mathrm{c} \mathrm{oz}, 40 \mathrm{e} \frac{1}{4} \mathrm{lb}$.

Extra Early Red. Matures rery early and yields abundantly, mild flavor, medium size, deep red in color, very close-grained, solid and hears, often forming bulbs in close and mucky soils where other rarieties fail. $5 \mathrm{c} \frac{1}{4} \mathrm{oz}, 10 \mathrm{e} \mathrm{oz}, 20 \mathrm{c} \mathrm{oz}, 50 \mathrm{c} 1 / 4 \mathrm{lb}$.

Queen. Silver-skinned, of quick growth and remarkable keeping qualities, valuable particularly for pickles. Our seed is very fine. $5 \mathrm{c} 1 / 4 \mathrm{oz}, 10 \mathrm{c} 1 / 2 \mathrm{oz}, 20 \mathrm{c} \mathrm{oz}, 65 \mathrm{c} 1 / 4 \mathrm{lb}$.

White Portugal, or Silver Skin. Ripens early, mild and pleasant in flavor, handsome silvery white skin, for pickling and early winter market. $5 \mathrm{c} 1 / 4 \mathrm{oz}, 20 \mathrm{c} \mathrm{oz}, 65 \mathrm{c} 1 / 4 \mathrm{lb}$.

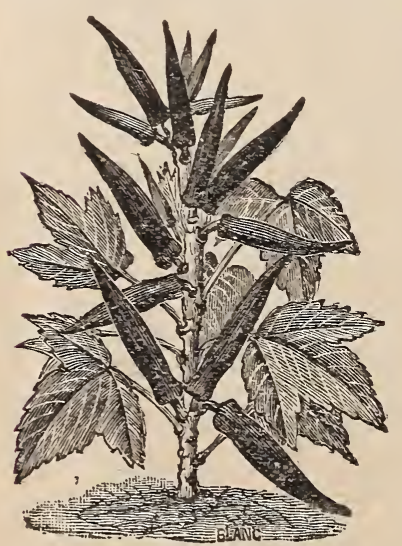

Okra or Gumbo.

Mammoth Silver King. Enormously large and flat, weighing two $\mathrm{Or}^{\circ}$ three pounds, snow white, mild and pleasant. $5 \mathrm{c} 1 / 1 \mathrm{oz}, 10 \mathrm{c} 1 / 2 \mathrm{oz}, 20 \mathrm{c} \mathrm{oz}, 65 \mathrm{c} 1 / \mathrm{s} 1 \mathrm{~b}$.

Prize=Taker, or Spanish King. Immense, 18 to 20 inches in circumference, nearly globe-shape, thin skin of straw color. pure white flesh, fine grained, mild and delicate flavor. $5 \mathrm{c} 1 / 4 \mathrm{oz}, 10 \mathrm{c} 1 / 2 \mathrm{oz}, 15 \mathrm{c} \mathrm{oz}, 40 \mathrm{c} 1 / 4 \mathrm{lb}$.

Large White Globe. Yields most abundantly, fine grained and mild. $5 \mathrm{c} 1 / 4 \mathrm{oz}, 10 \mathrm{c} 1 / 2 \mathrm{oz}, 20 \mathrm{c} \mathrm{oz}, 65 \mathrm{c} 1 / 4 \mathrm{lb}$.

ONION SETS AT MARKET RATES.

\section{OKRA OR GUMBO.}

White Velvet. (See cut.) Decidedly the best rarietr. Pods perfectly round and smooth, with an attractire white relvety appearance, and of superior flaror and tenderness. Comparatively dwarf, of compact and branching growth, the extra large pods are produced in great abundance. No trouble to grow in any good soil. Gather the pods when quite green and about an inch and a half long. $5 \mathrm{c} 1 / 2 \mathrm{oz}, 10 \mathrm{c} \mathrm{oz}, 25 \mathrm{c} 1 / 4 \mathrm{lb}$. 


\section{PEPPER.}

One ounce of seed for fifteen hundred plants.

Sweet Mountain. (See cut.) Fruit rery large, often eight inches or more in length by two or three in diameter, rery smooth and handsome, being when green of a bright deep green color, entirely free from any purple tinge, and when mature of a rich red. Flesh rery thick, sweet and mild flarored. Well suited for use as a stuff pickle. $5 \mathrm{c} \frac{1}{1 / \mathrm{oz}}, 10 \mathrm{c} \frac{1}{2} \mathrm{oz}, 20 \mathrm{c} \mathrm{oz}$.

Large Bell or Bull Nose. A large and early variety of mild flaror, rind thick and fleshy, the best for pickling and pepper sauce, or filled as mangoes. $5 \mathrm{c} 1 / 4$ oz, $10 \mathrm{e} 1 / 2 \mathrm{oz}, 20 \mathrm{e} \mathrm{oz}$.

Ruby King. Best and most profitable mild red pepper for market or famils use. The peppers ordinarils grow from four and a half to six inches long by three and a half to four and a quarter inches through. Beautiful color, mild and pleasant to the taste, in this respect unequalled by any other Red Pepper. Excellent for stuffing or for pepper sauce. $5 \mathrm{c} \frac{1 / 4}{\mathrm{oz}}, 10 \mathrm{c} \frac{1 / 2}{\mathrm{Oz}}, 20 \mathrm{c} \mathrm{oz}$.

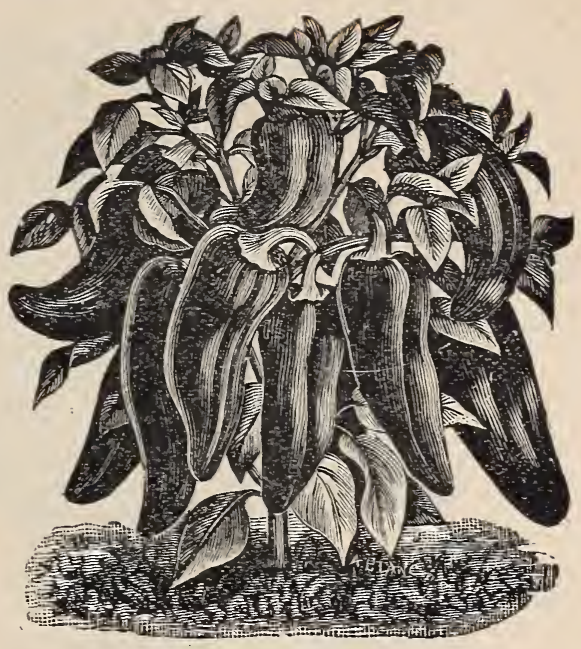

Sweet Mountain

Large Red Cayenne. From three to four inches long, bright red color, very productire and hot; pods slim, long and pointed, the true Cayenne and the best of its kind. $5 \mathrm{c} 1 / 4 \mathrm{oz}, 10 \mathrm{c} 1 / 2 \mathrm{oz}, 20 \mathrm{c} \mathrm{oz}$.

Coral Gem Bouquet. One of the finest of the small-sized rarieties. Hundreds of the small bright red peppers are so thickly set on the dwarf plants as to gire each plant the appearance of a "bouquet of corals." Intensely hot, smooth and pretty. 5c $1 / 4 \mathrm{oz}$, $10 \mathrm{c} \frac{1 / 2}{2} \mathrm{oz}, 20 \mathrm{coz}$.

Golden Dawn. A magnificent yellow pepper of the bell class, mild, sweet and rery productive. $5 \mathrm{c} \frac{1 / 4}{\mathrm{oz}}, 10 \mathrm{c} \frac{1}{2} \mathrm{oz}, 20 \mathrm{e} \mathrm{oz}$.

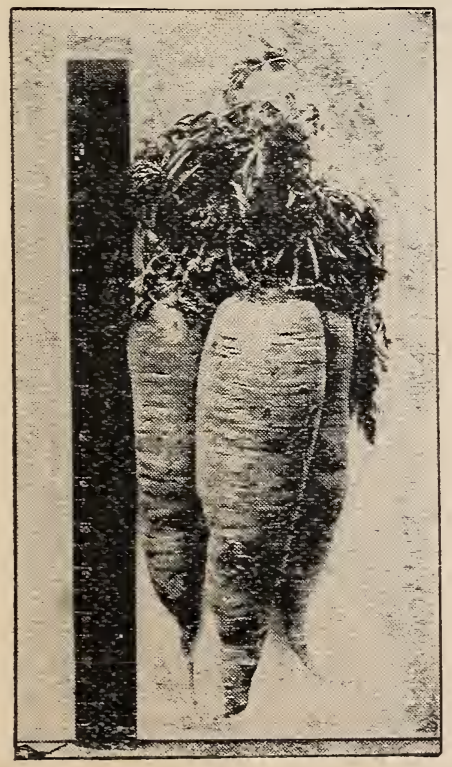

Large Sugar or Hollow Crown.
Long. Yellow. An ornamental rariety, similar to Large Red Cayemne, except in color. 5e $1 / t \mathrm{oz}$, $10 \mathrm{c} 1 / 2 \mathrm{oz}, 20 \mathrm{c} \mathrm{oz}$.

Small Chili. Free branching, bush-like growth, fifteen inches high, haring numerous large cluster's of bright red, conical pods, about three inches long and one-half inch in diameter, vers hot and prolific, and ripens early; used for seasoning and sauces. $5 \mathrm{c} 1 / 4 \mathrm{oz}, 10 \mathrm{c} 1 / 2 \mathrm{oz}, 20 \mathrm{c} \mathrm{oz}$.

\section{PARSLEY.}

One ounce to fifty feet of drill.

Fine Double Curled. A fine dwarf rariety with crimped leares, and inraluable as a garnishing plant. Bright, pale green, and exceedingly handsome. $5 \mathrm{c} \frac{1}{2} \mathrm{oz}, 10 \mathrm{c} \mathrm{oz}, 20 \mathrm{c} 1 / 4 \mathrm{lb}$.

\section{PARSNIPS.}

One ounce to two hundred feet of drill; five or six pounds to the acre.

Large Sugar or Hollow Crown. (Improred Guernser.) (See cut.) Acknowledged to be the best rariety in cultiration for general use. Roots are intermediate in length, white, smooth, sugary, of most excellent flaror and easily harrested. 5c $1 / 4 \mathrm{oz}, 10 \mathrm{c} \mathrm{oz}, 20 \mathrm{c} \frac{1 / 4}{1} \mathrm{lb}, 50 \mathrm{c} \mathrm{lb}$. 


\section{PEAS.}

One quart to sixty feet of row. If by mail add se pint, $15 \mathrm{c}$ quart.

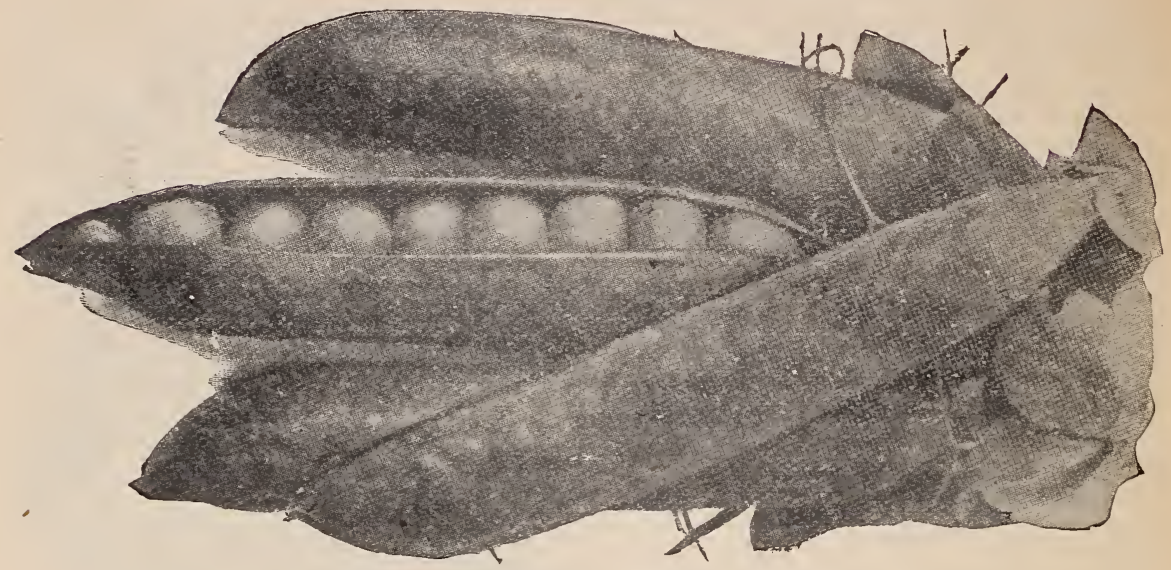

Long Islanc Mammoth.

\section{EXTRA EARLY SORTS.}

Alaska, or Earliest of All. By the most careful selection and growing there has been dereloped a stock of this smooth blue pea, which in erenness of growth of vine and early maturity of pods is mnequalled by any other extra early pea. Tines two to two and one-half feet high, unbranched, bearing four to seren long pods filled with mediumsized dark green peas of excellent flaror. Ripe peas small and bluish green. Ripens in about 48 days, all the pods at once. $5 \mathrm{c} \frac{1}{2}$ pint, $10 \mathrm{e}$ pint, $20 \mathrm{e}$ quart.

Gradus or Prosperity. New first early, hardy wrinkled variety of the highest type of perfection; rigorous grower, $2 \frac{1}{2}$ feet in height, light green color, pods and peas of very large size and closely resembling Telephone, maturing only three days after Alaska, and claimed to be the earliest wrinkled pea known. Pods pioduce from 6 to 8 peas of enormous size, rich, sweet and mellow. Highest a ward and first-class certificate at the Royal Horticultural Society, England. 10e packet, postpaid; 30e pint, 50e quart.

Nott's Excelsior. The best dwarf extra early pea; 54 days. Vines are larger and more vigorous than the American Wonder, 11/2 feet, and earlier and more prolific than Premium Gem, while the peas have no equal in sweetness and quality. Wre consider this variety one of the best of recent introduction. Pods always well filled; best of all for the home garden. $8 \mathrm{c} \frac{1}{2}$ pint, $15 \mathrm{c}$ pint, $25 \mathrm{c}$ quart.

Premium Gem. Extra early, 12 to 15 inches, pods large and abundant, peas green, wrinkled, and of excellent quality. Profitable for market gardener's and good for home use; 54 days. $8 \mathrm{c} \frac{1}{2}$ pint, $15 \mathrm{c}$ pint, $25 \mathrm{c}$ quart.

First and Best. Extremely early, productive, and ripen all at the same time; $2 \frac{11}{2}$ feet; 54 davs. $5 \mathrm{c} \frac{1 / 2}{2}$ pint, $10 \mathrm{c}$ pint, $20 \mathrm{c}$ quart.

Bliss' American Wonder. One of the very best of the earliest wrinkled peas and a superior cropper, bearing large, well filled pods, haring six to nine large peas in each; vines 10 to 12 inches high and of robust habit; 52 days. $8 \mathrm{c} \frac{1}{2}$ pint, $15 \mathrm{c}$ pint, $25 \mathrm{c}$ quart.

\section{SECOND EARLY SORTS.}

Bliss' Everbearing. Fine wrinkled sort, about 30 inches high, very robust and bearing heavy crops of large, well filled pods; peas of excellent flavor. Owing to its branching habit, peas should be planted about six inches apart. $5 \mathrm{c} \frac{1}{2} \mathrm{pt}, 10 \mathrm{cpt}, 20 \mathrm{c} \mathrm{qt}$.

McLean's Advancer. Fine early market rariety, exceedingly prolific, with pods of green wrinkled peas of fine flavor; known as Dwarf Champion in some localities. Vines 2 to $2 \frac{1}{2}$ feet high; 55 days. $5 \mathrm{c} \frac{1}{2}$ pint, $10 \mathrm{c}$ pint, $20 \mathrm{c}$ quart.

The Admiral. Tery heary cropping wrinkled pea, ripens with Telephone, and remains palatable longer than any other variety after it becomes large enough to use. Vines three to four feet high. $5 \mathrm{c} \frac{1}{2}$ pint, $10 \mathrm{c}$ pint, $20 \mathrm{c}$ quart.

Long Island Mammoth. (See cut.) Earlier than Champion of England; 60 days; 42 inches; excellent cropper. Pods of large size and well filled with green peas of excellent quality. Popular with eastern truckers and gardeners. $5 \mathrm{c} \frac{1}{2} \mathrm{pt}, 10 \mathrm{c} \mathrm{pt}, 20 \mathrm{c}$ q $\mathrm{t}$. 
Telephone. Fine, tall, wrinkled rariety, and a great cropper, bearing immense pods full of large peas of exquisite flaror; decidedly a market garden pea, the large pods filling a basket quicker than any other variety. Four feet, 65 days. 5c $1 / 1 / 4$ pint, 8 c $1 / 2$ pint, $15 \mathrm{c}$ pint, $25 \mathrm{c}$ quart.

\section{LATE OR MAIN CROP PEAS.}

Sharpe's Queen. Most desirable of the late rarieties recently introduced, rigorons, branching habit, and needs to be sown thinly: pods long and slightly curved, well filled with large peas of most delicious flaror. Its beauty and productireness. combined with high quality, make it exceedingly popular. Height $2 \frac{1}{2}$ feet, seed dark green, wrinkled. $8 \mathrm{c} \frac{1}{2}$ pint, $15 \mathrm{c}$ pint, $25 \mathrm{c}$ quart.

Dwarf Telephone. (Carter's Daisr.) Excellent new rariety; large, well-filled pods; peas of fine flavor. Height $1 \frac{1}{2} \mathrm{ft}$. $8 \mathrm{c} \frac{1 / 2}{2}$ pint, $15 \mathrm{c}$ pint, $25 \mathrm{c}$ quart.

Champion of England. Standard rariety, popular ererywhere, and one of the richest and best flarored green wrinkled peas; rery productire; fire feet, 70 days. $5 \mathrm{c} 1 / 2$ pint, $10 \mathrm{c}$ pint, $15 \mathrm{c}$ quart.

Large White Marrowfat. Pods large, cylindrical, rough, light-colored and well filled. Seeds large, smooth, yellow or white, the color being somewhat affected by the soil in which they grow; four feet. $5 \mathrm{c} \frac{1}{2}$ pint, sc pint, $15 \mathrm{c}$ quart.

Large Black=eyed Marrowfat. An old-time farorite; large, handsome, well-filled pods and an enormous cropper; four feet. $5 \mathrm{c} \frac{1}{2} \mathrm{pint}, 8 \mathrm{c}$ pint, $15 \mathrm{c}$ quart.

Melting Sugar. (Edible-podded.) Large, sweet, brittle and succulent pods, used in the same way as snap or string beans; well named and the best of its class. $5 \mathrm{c} 1 / 4$ pint, $8 \mathrm{c} \frac{1}{2}$ pint, $15 \mathrm{c}$ pint, $25 \mathrm{c}$ quart.

\section{PUMPKINS.}

One ounce will plant about twenty-fire hills; four pounds to the acre.

Improved Cashaw. This is the genuine Cashaw of olden times-a distinct mottled green in color, with white stripes. The flesh is a rich vellow, solid, fine grained, very sweet and excellent for pies. Its great productireness and richness make it raluable to grow in the cornfield for feeding stock. $5 \mathrm{c} \frac{1}{2} \mathrm{oz}, 8 \mathrm{c} \mathrm{oz}, 20 \mathrm{c} 1 / 4 \mathrm{lb}, 50 \mathrm{c} \mathrm{lb}$.

Quaker Pie. Distinct variety, oral in shape, creamy color inside and out. The flesh is fine-grained, rery rich-fla vored and makes superior pies. It is an excellent keeper, and the rines are hardy and prolific. $5 \mathrm{c} \frac{1}{2} \mathrm{oz}, 10 \mathrm{c} \mathrm{oz}, 20 \mathrm{c} \frac{1}{4} \mathrm{lb}$.

Large Cheese, or Kentucky Field. (See cut.) Shaped like a cheese, and in flavor like a crook-neck squash. The flesh is rellow and fine-grained-one of the rery best field pumpkins. $5 \mathrm{c} \frac{1}{2} \mathrm{oz}, 10 \mathrm{c} \mathrm{oz}, 20 \mathrm{c} 1 / 4 \mathrm{lb}$.

Tennessee Sweet Potato. Of medium size and pear-shaped: both skin and flesh are of a creamy-white in color, rery thick, fine grained, dry, and of most excellent flaror. It keeps well until spring, one of the rery best for pies, and is a great favorite in the south. $5 \mathrm{c} \frac{1}{2} \mathrm{oz}, 10 \mathrm{c} \mathrm{oz}, 20 \mathrm{c} 1 / 4 \mathrm{lb}$.

Large Field. "The Yankee Cow Pumpkin." Choice seed from fully ripe selected specimens-just the kind to plant for a big crop. 5c oz, $20 \mathrm{c} \mathrm{lb.}$

Japanese Pie. A rariety with rery thick flesh, fine-grained and one of the sweetest; makes the finest pies of any rariety known; very productire; seeds sculptured. $5 \mathrm{c} \frac{1}{2} \mathrm{oz}$, $10 \mathrm{c} \mathrm{oz}, 20 \mathrm{c} 1 / 4 \mathrm{lb}$.

Mammoth. This is the big show mumpkin, which is catalogued under the rarious names of "King of the Nammoths," "Jumbo," "True Potiron," "\$50) Prize," etc. Specimens have weighed orer 200 pounds and three or four feet in circumference. Skin is salmon, flesh bright yellow, and keens a lorg time. Its greatest ralue, except for feeding stock, is to hare the "biggest pumpkin" for the fair, and our seed is that kind. $5 \mathrm{c} 1 / 2$ $\mathrm{oz}, 10 \mathrm{c} \mathrm{oz}, 20 \mathrm{c} 1 / 4 \mathrm{lb}$.

Never mix Squash and Pumpkin seeds when planting if you value Squash flaror.

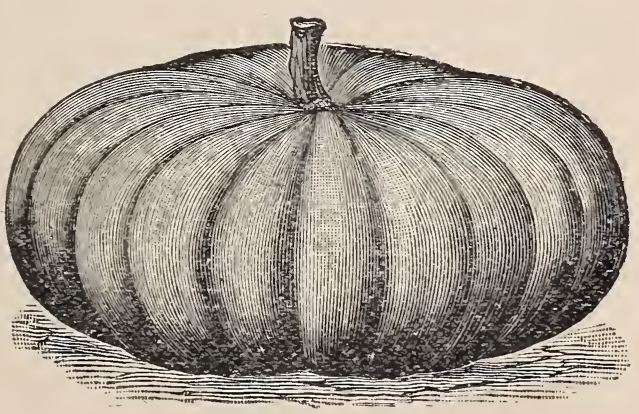

Large Cheese. 


\section{RADISH.}

One ounce of seed will sow one hundred feet of drill.

Pearl Forcing. Color pearl white and of waxy appearance, texture very firm and solid; remains in eatable condition fully two weeks before showing signs of going to seed, and does not become woody. $5 \mathrm{c} \frac{1}{2} \mathrm{oz}, 10 \mathrm{c} \mathrm{oz}, 25 \mathrm{c} 1 / 4 \mathrm{lb}$.

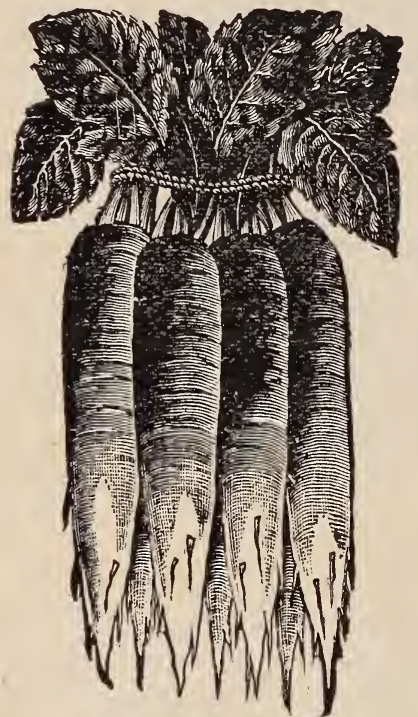

Beckert's Chartier.

White Box. Perfectly round, sinooth skin, pure white, and free from any sharpness or bitterness; a remarkably quick grower, with rery small top, having but three short leaves on a fully matured root; very fine for forcing. $5 \mathrm{c} 1 / 2 \mathrm{oz}, 10 \mathrm{c} \mathrm{oz}, 25 \mathrm{c} 1 / 4 \mathrm{lb}$.

Glass. For forcing, half long, rose pink in color. $5 \mathrm{c} 1 / 2 \mathrm{oz}, 10 \mathrm{c} \mathrm{oz}, 25 \mathrm{c} 1 / 4 \mathrm{lb}$.

Early Scarlet Globe. Fine for forcing and the market garden: roundish oval, brilliant red skin, flesh white, solid and crisp, very mild, small tops. $5 \mathrm{c} \frac{1}{2} \mathrm{oz}$, $10 \mathrm{c} \mathrm{oz}, 25 \mathrm{c} 1 / 4 \mathrm{lb}$.

French Breakfast. Beautiful scarlet color, with sinall top, medium in size, and very rapid growth. $5 \mathrm{c} 1 / 2 \mathrm{oz}, 10 \mathrm{c} \mathrm{oz}, 25 \mathrm{c} 1 / 4 \mathrm{lb}$.

Wood's Early Frame. Ten days earlier than Long Scarlet, which it resembles; an elegant forcing variety. $5 \mathrm{c} 1 / 2 \mathrm{oz}, 10 \mathrm{c} \mathrm{oz}, 25 \mathrm{c} 1 / 4 \mathrm{lb}$.

Golden Globe. Very popular in the south; of quick growth, tender and brittle; perfect globe shape, and skin of golden color. $5 \mathrm{c} 1 / 2 \mathrm{oz}, 10 \mathrm{c} \mathrm{oz}, 25 \mathrm{c} \frac{1}{4} \mathrm{lb}$.

Scarlet Turnip White Tip. For forcing and outdoor planting; top and roots small, scarlet skin, flesh very mild and crisp. $5 \mathrm{c} 1 / 2 \mathrm{oz}, 10 \mathrm{c} \mathrm{oz}, 25 \mathrm{c} 1 / 4 \mathrm{lb}$.

Beckert's Chartier. (See cut.) Very attractive, bright salmon color shading to white as it approaches maturity; crisp, tender, mild and pleasant flavor-the Pittsburg favorite. Extra fine for the kitchen garden, quality being unexcelled. $5 \mathrm{c} \frac{1 / 2}{\mathrm{oz}}, 10 \mathrm{c} \mathrm{oz}, 25 \mathrm{c} \frac{1 / 4}{4} \mathrm{~b}$.

Cincinnati Market. (See cut.) Handsomest long variety in cultivation, in color a beautiful glossy scarlet, very small top, six to seven inches long, very thin skin, flesh crisp and brittle, and of a delightful pungent quality. Finest long red radish for forcing, and extra fine for the home garden.

White Strausberg. Roots oblong and pure white, very brittle and mild, retaining its good qualities eren when the roots become large and old. $5 \mathrm{c} 1 / 2 \mathrm{oz}, 10 \mathrm{c} \mathrm{oz}, 25 \mathrm{c} 1 / 4 \mathrm{lb}$.

Early Long Scarlet Short Top Improved. Grows six or seven inches long. half out of the ground, very brittle and crisp, color bright scarlet. quick growth, with very short top. $5 \mathrm{c} \frac{1}{2} \mathrm{oz}, 10 \mathrm{coz}, 25 \mathrm{c} \frac{1}{4} \mathrm{lb}$.

Long White Vienna, or Lady Finger. Long and tapering roots, inild flavor, pure white, tender, crisp and fine in all respects. $5 \mathrm{c} 1 / 2 \mathrm{oz}, 10 \mathrm{c}$ $\mathrm{oz}, 25 \mathrm{c} 1 / 4 \mathrm{lb}$.

Half Long Black SpanishWinter. Large, long, hardy, firm texture, and keeps well; black skin, flesh white and slightly pungent. $5 \mathrm{c} 1 / 2 \mathrm{oz}, 10 \mathrm{c} \mathrm{oz}$, $25 \mathrm{c} \frac{1}{4} \mathrm{lb}$.

Scarlet China Winter. Skin light rose, flesh white and firm. $5 \mathrm{c} 1 / 2 \mathrm{oz}$, $10 \mathrm{c} \mathrm{oz}, 25 \mathrm{c} 1 / 4 \mathrm{lb}$.

Large White Spanish. Winter. Flesh solid and milder fiavor than the black sorts. $5 \mathrm{c} \frac{1}{2} \mathrm{Oz}, 10 \mathrm{c} \mathrm{oz}, 25 \mathrm{c} \frac{1 / 4}{4} \mathrm{lb}$. $5 \mathrm{c} \frac{1}{2} \mathrm{oz}, 10 \mathrm{c} \mathrm{oz}, 25 \mathrm{c} 1 / 4 \mathrm{lb}$.

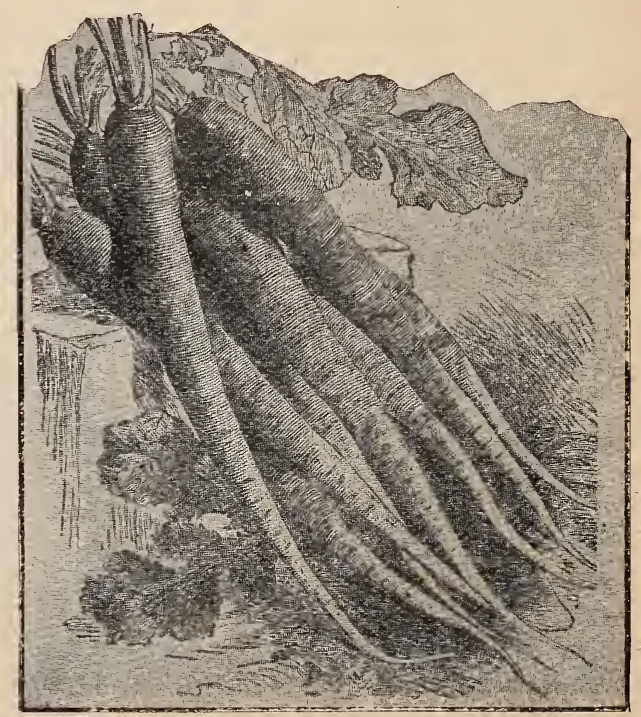

Cincinnati Market. 


\section{SQUASH.}

One ounce will plant fifty hills. Four to six pounds to the acre, according to variety.

\section{SUMMER SQUASH.}

Mammoth White Bush Scalloped. Earlier and double the size of common variety, bears early and until late in the fall; splendid for market. $5 \mathrm{c} \frac{1}{2} \mathrm{oz}, 10 \mathrm{c} \mathrm{oz}, 25 \mathrm{c} \frac{1}{4} \mathrm{lb}$.

Mammoth Summer Crookneck. Golden skin covered with fine warts, especially fine and delicate flavor; earliness, large size, wartiness combined. $5 \mathrm{c} \frac{1}{2} \mathrm{Oz}, 10 \mathrm{c} \mathrm{oz}, 25 \mathrm{c} \frac{1}{1} \mathrm{lb}$.

\section{AUTUMN AP:D WINTER SORTS.}

Hubbard. Well known standard rariety; flesh bright orange rellow, fine grained. very dry, sweet and rich flarored; bakes as dry as a sweet potato; the best keeper, and a grand variety. $5 \mathrm{c} \frac{1}{2} \mathrm{oz}, 10 \mathrm{c} \mathrm{oz}, 25 \mathrm{c} \frac{1}{4} \mathrm{lb}$.

Golden Hubbard. (See (cut.) A sport from the old standard of excellence, of which it is a perfect type, except in color: flesh deep golden vellow, fine grained, cooks dry, and of excellent flavor. $5 \mathrm{c} \frac{1}{2} \mathrm{oz}, 10 \mathrm{c} \mathrm{oz}, 25 \mathrm{c}$ $1 / 4 \mathrm{lb}$.

Chicago Warted Hub= bard. Large, dark green almost black in color, corered densely with warts or knots; flesh is very thick, in quality first-class, and an excellent keeper. $5 \mathrm{c} \frac{1}{2} \mathrm{oz}$, $10 \mathrm{c} \mathrm{oz}, 25 \mathrm{c} 1 / 4 \mathrm{lb}$.

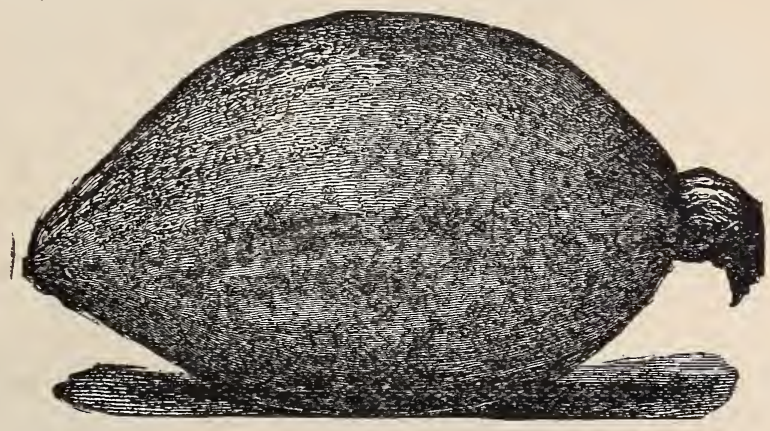

Golden Hubbard.

Green Mountain. Larger than Hubbard, and has a beautiful netting of dark green instead of warts; flesh deep orange red; cooks quickly and evenly, and is best for pies; early vines, hardy and mature large crops. $5 \mathrm{c} \frac{1}{2} \mathrm{oz}, 10 \mathrm{c} \mathrm{oz}, 25 \mathrm{c} 1 / 4 \mathrm{lb}$.

Faxon. Medium in size, very early and productire, orange-colored flesh of the finest quality. $5 \mathrm{c} \frac{1}{2} \mathrm{oz}, 10 \mathrm{coz}, 25 \mathrm{c} 1 / \mathrm{l} \mathrm{lb}$.

Boston Marrow. Thin, bright orange skin, rich salmon yellow flesh, fine grained, sweet and dry, good keeper, and splendid table squash. $5 \mathrm{c} 1 / 2 \mathrm{oz}, 10 \mathrm{c} \mathrm{oz}, 25 \mathrm{c} 1 / 4 \mathrm{lb}$.

Fordhook. Flesh dry and sweet, will not rot, early, productive, sure cropper, thin skin, thick meat, and small seed carity; most convenient size for family use, and keeps until June in a cool, dry place. $5 \mathrm{c} \frac{1}{2} \mathrm{oz}, 10 \mathrm{c} \mathrm{oz}, 25 \mathrm{c} 1 / 4 \mathrm{lb}$.

Essex Hybrid, or Hard Shelled Turban. Standard winter sort, the flesh a trifie darker than Hubbard. $5 \mathrm{c} \frac{1}{2} \mathrm{oz}, 10 \mathrm{c} \mathrm{oz}, 25 \mathrm{c} 1 / 1 / 1 \mathrm{lb}$.

Pike's Peak, or Sib!ey. One of the srreetest. drrest and bast late squashes. Pearshaped, with stem on larger end; shell smooth, hard, flinty and pale green; flesh thick and solid, brilliant orange color, drs, fine grained, and rich and delicate flavor; weighs eight to ten pounds, $5 \mathrm{c} \frac{1}{2} \mathrm{oz}, 10 \mathrm{coz}, 25 \mathrm{c} \frac{1}{1 /} \mathrm{lb}$.

\section{SALSIFY, OR VEGETABLE OYSTER.}

Cultivation the same as parsnips. Hardy and can remain in the ground all winter for use in the early spring. One ounce to seventy feet of drill.

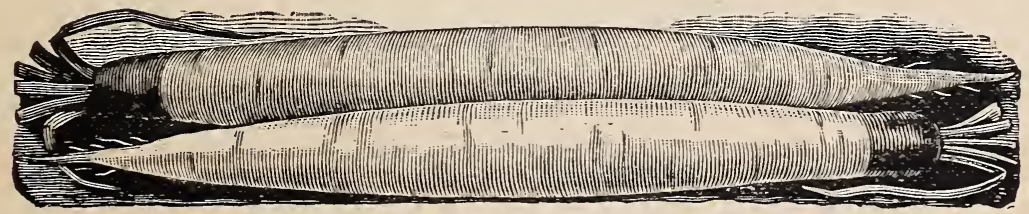

Mammoth Sandwich Island Salsify.

Mammoth Sandwich Island. (See cut.) Grows to rery large size and resembles a good sized parsnip; mild and delicate in flavor, and though of recent introduction, has already found its way to popular faror. $5 \mathrm{c} \frac{1}{2} \mathrm{oz}, 10 \mathrm{c} \mathrm{oz}, 25 \mathrm{c} 1 / 41 \mathrm{~b}$. 


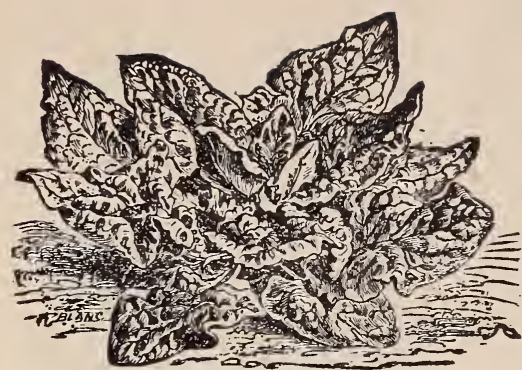

New Victoria Spinach.

\section{SPINACH.}

One ounce to 100 feet of drill. On dry land seed should be rolled or tramped in to make it germinate.

New Victoria. (See cut.) Heavy foliage, broad dark green leaves of true Saroy appearance, fine quality, in prime condition after all others have seeded. $5 \mathrm{c} 1 / 2 \mathrm{oz}, 10 \mathrm{c} \mathrm{oz}, 40 \mathrm{c} \mathrm{lb}$.

Round Summer Broad Leaf. Thick and fleshy leares. $5 \mathrm{c} \frac{1}{2} \mathrm{oz}, 10 \mathrm{c} \mathrm{oz}, 30 \mathrm{c} \mathrm{lb}$.

Improved Thick=Leaved, or Long Stand= ing. Large, thick, fleshy. Savoy-leaved, and will stand two weeks longer than any other kind before shooting to seed; best for spring sowing. $5 \mathrm{c} 1 / 2 \mathrm{oz}, 10 \mathrm{c} \mathrm{oz}, 35 \mathrm{c} \mathrm{lb}$.

Fall, or Prickly Seeded. The hardiest variety, but the leaves are smaller, and it is not is productive. $5 \mathrm{c} 1 / 2 \mathrm{oz}, 10 \mathrm{c} \mathrm{oz}, 35 \mathrm{c} \mathrm{lb.}$

\section{TURNIPS.}

One ounce to 150 fzet of drill; one to two pounds in drills per acre.

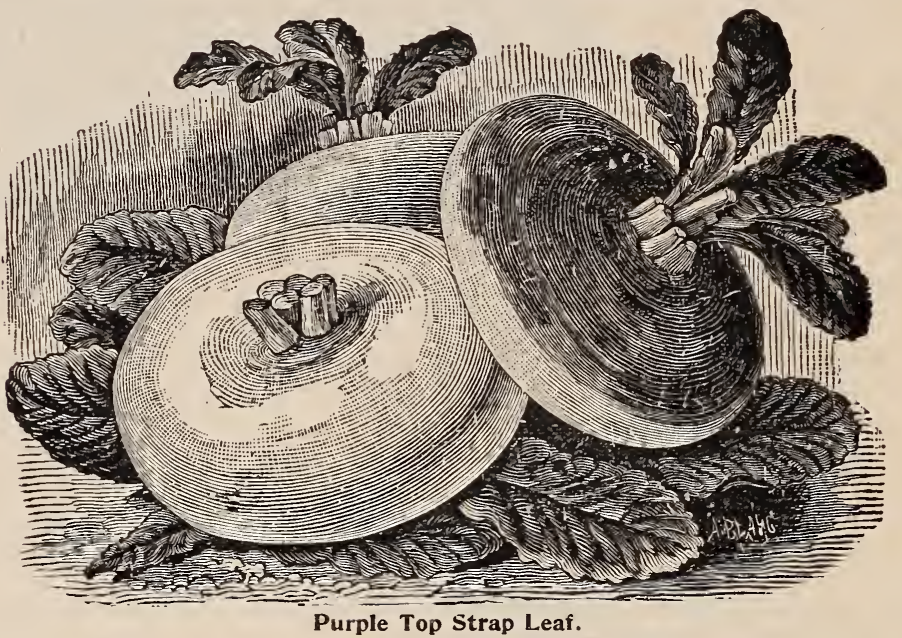

Red or Purple Top Strap Leaf. (See cut.) Most widely cultivated and best known variety, mostly used for sowing broadcast among corn and potatoes; round, flat, very quick grower, white on bottom and reddish purple abore ground. Highly esteemed as a table variety, and also used for stock feeding. $5 \mathrm{c} \mathrm{oz}, 15 \mathrm{c} 1 / 4 \mathrm{lb}$.

Red Top White Globe. One of the best early varieties, large size and rapid growth, globe-shaped, with red or purple top,-fine quality, keeps well, and excellent for early or winter market. $5 \mathrm{c} \mathrm{oz}, 15 \mathrm{c} 1 / 4 \mathrm{lb}$.

Early White Flat Dutch. Strap-leaf variety and largely used in the south, roots medium-sized and flat, color white, very early, sweet and tender. $5 \mathrm{c} \mathrm{oz}, 15 \mathrm{c} 1 / 4 \mathrm{lb}$.

Extra Early Purple Top Milan. Earliest in cultivation, and favorite with gardeners who want the first. White bulb, flat, medium size, top bright purple, sweet and fine flarored. $5 \mathrm{c} \mathrm{oz}, 15 \mathrm{c} 1 / \mathrm{lb}$.

Yellow Stone. Splendid for general crop, large size, yellow flesh, firm and street, keeps well until spring, excelient for table or stock-feeding. $5 \mathrm{c}$ oz, $15 \mathrm{c} 1 / 4 \mathrm{lb}$.

White Russian, or Large Ruta Baga. Superior white-fleshed and white-skinned variety, very sweet and desirable for table or stock. $5 \mathrm{c} \mathrm{oz}, 15 \mathrm{c} 1 / 4 \mathrm{lb}$.

\section{TOBACCO.}

Connecticut Seed Leaf. Best adapted for middle and northern states, as it is more hardy and endures cold better; user for cigar wrapper's. 5c packet, $40 \mathrm{c} \mathrm{oz}$.

Fine Havana. Pure Cuban grown seed from the famous Vuelta de Abajo district, and commands rery high prices for the best cigar stock. $5 \mathrm{c}$ packet, $40 \mathrm{coz}$. 


\section{TOMATOES.}

One ounce of seed will produce 1500 plants Four ounces will produce enough for an acre.

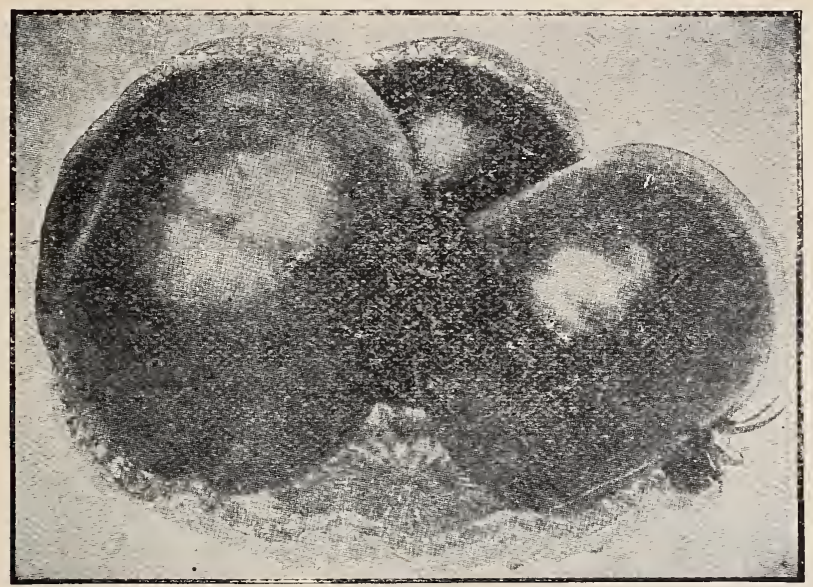

Imlay's Long Island.

Imlay's Long Island. (See cut.) Chanced to pick up this new tomato during an eastern trip several years ago, and gave it a trial along with thirty-six other varieties. It proved a little better than Stone or any other sort-in fact, the best for general purposes. Several hundred trial packets produced some very flattering testimonials, and I have taken great pleasure in offering it to the trade. Bright scarlet in color. large and solid, ripens perfectly and does not crack-the best all round variety ever introduced. Be sure and include it in your order. $5 \mathrm{c}$ packet, $10 \mathrm{c} 1 / 4 \mathrm{oz}, 35 \mathrm{coz}$.

Enormous. Largest of all, hardiest, best keeper, most productive and handsomest red tomato. Vines very strong, vigorous growth, producing heavy crops of extra large, smooth, solid fruits, handsomely colored, and measuring four to five, and even six inches across, smooth, solid, free from cracks or blemishes. $10 \mathrm{c} 1 / 4 \mathrm{oz}, 20 \mathrm{c} \mathrm{oz}, 75 \mathrm{c} 1 / 4 \mathrm{lb}$.

Stone. Very large and smooth, bright scarlet, ripening evenly to the stem without cracking, exceedingly solid and firm, not subject to rot, very heavy and attractive fruit, vines and foliage rank and robust, always heavily loaded. $5 \mathrm{c} \frac{1}{4} \mathrm{oz}, 20 \mathrm{c} \mathrm{oz}, 60 \mathrm{c} 1 / 4 \mathrm{lb}$.

Beauty. One of Livingston's best. Very large, smooth, solid and purplish-pink skin, flesh light pink color, vigorous grower, splendid keeper, good shipper. Same color as Acme, larger in size and not so liable to rot. $5 c 1 / 4 \mathrm{oz}, 20 \mathrm{c} \mathrm{oz}, 60 \mathrm{c} 1 / 4 \mathrm{lb}$.

Improved Trophy. Bright red color, and its size and solidity entitle it to hold place against many of the much lauded new kinds. $5 \mathrm{c} 1 / 4 \mathrm{oz}, 20 \mathrm{c} \mathrm{oz}, 60 \mathrm{c} 1 / 4 \mathrm{lb}$.

Favorite. The canner's favorite, and one of the largest perfect-shaped red tomatoes cultivated. Ripens evenly and as early as any other good red, free from cracks and rot, very prolific, good flavor, few seeds, solid flesh, ships well. $5 \mathrm{c} 1 / 4 \mathrm{oz}, 20 \mathrm{c} \mathrm{oz}, 65 \mathrm{c} 1 / 4 \mathrm{lb}$.

Buckeye State. Large, smooth and uniform in size, very prolific, solid and meaty, purple in color, a shade darker than Beauty. $5 \mathrm{c} 1 / 4 \mathrm{oz}, 20 \mathrm{c} \mathrm{oz}, 65 \mathrm{c} 1 / 4 \mathrm{lb}$.

Ignotum. Very large, smooth and regular in form, remarkably solid, few seeds, deep red color, ripens perfectly to the stem, unusually productive, and holds its large size well to the close of the season. $5 \mathrm{c} 1 / 4 \mathrm{oz}, 20 \mathrm{c} \mathrm{oz}, 60 \mathrm{c} 1 / 4 \mathrm{lb}$.

Dwarf Champion. Very early, purplish, without pink color, two feet high, standing erect, smooth, fairly solid, no hard core, good flavor. $5 \mathrm{c} 1 / 4 \mathrm{oz}, 20 \mathrm{c} \mathrm{oz}, 60 \mathrm{c} 1 / 4 \mathrm{lb}$.

Atlantic Prize. One of the earliest of all; not only ripens its fruit first, but a large proportion of the main crop ahead of any other sort. $5 \mathrm{c} 1 / 4 \mathrm{oz}, 20 \mathrm{c} \mathrm{oz}, 75 \mathrm{c} 1 / 4 \mathrm{lb}$.

Early Acme. One of the earliest, fruit medium size, perfectly smooth and regular in shape. color distinct dark red with purplish tinge. $5 \mathrm{c} 1 / 4 \mathrm{Oz}, 20 \mathrm{c} \mathrm{oz}, 75 \mathrm{c} 1 / 4 \mathrm{lb}$.

Essex Early Hybrid. Handsome bright pink tomato, quite early, solid and richflavored, large, smooth, very productive. $5 \mathrm{c} 1 / 4 \mathrm{oz}, 20 \mathrm{c} \mathrm{oz}, 60 \mathrm{c} 1 / 4 \mathrm{lb}$.

Yellow Pear. Clear deep vellow, small size, for preserves. 5c packet.

Golden Queen. Real good yellow sort, first class quality, for table fruit as well as preserves; fruit large, solid, smooth and beautiful. $5 \mathrm{c} 1 / 4 \mathrm{oz}, 20 \mathrm{coz}$.

Strawberry. (Winter Cherry or Husk.) Grows in a husk, excellent for preserves, very sweet flavored, small yellow fruit, can be kept all winter. 5c packet. 


\section{MISCELLANEOUS FARM SEEDS.}

In season we carry a complete line of miscellaneous seeds for the farm. Our large new warehouse gives us facilitiez for carrying stocks and supplying large orders with promptness. But as the market on these seeds is constantly fluctuating; we do not quote prices in this catalogue, but are ready at all times to give customers the lowest figures obtainable anywhere. As a rule, early buyers do the best. All prices are NF, T $\mathrm{CASH}$, purchasers paying transportation charges. We make no charge for cartage, and sell bags at cost.

\section{SEED CORN.}

First-class Seed Corn-fire dried and selected-will be scarce and high this year, on account of the very short corn crop. We liave made a great effort to provide ourselves with a good stock of choice seed for our customers. Practically all the corn we offer has been fire dried and all is select. Prices and list of varieties on application.

\section{CLOVERS.}

As prices on Clovers and Grass Seeds are varying almost daily, we do not give quotations, but will gladly quote prices and mail samples on applications.

Medium or Common Red. By far the most important of all varieties for practical purposes. Sow in spring or fall, and if no other grasses are used, at the rate of eight to twelve pounds per acre; more is required on old, stiff soils than on new and lighter ones.

Mammoth Pea Vine, or Large Red. Grows nearly twice the size of Common Red, coarse stalks, and used extensively for plowing under.

Crimson or Scarlet. Grows about one foot long, blooms early in May, furnishing an early green fodder, and is recommended for plowing under when in blossom.

Alsike or Swedish. Most hardy, and on rich soils yields an enormous quantity of hay and pasturage, and sown with other grasses forms a thick bottom.

Lucerne or Alfalfa. Has an immense penetrating root, and should be sown only on rich, moist loam, at the rate of fiteen to twenty-five pounds to the acre.

White Dutch. Small, creeping, perennial variety, valuable for pasturage and lawns. When used with other grasses, sow three pounds per acre.

\section{GRASSES.}

Timothy. The most valuable of all grasses for hay. It should be cut just when the blossom falls. Thrives best on moist loamy land, and if sown alone fifteen pounds to the acre.

Orchard Grass. Blooms with and does best with clover, and stands drought better than any other grass. Fifty pounds to the acre.

Rep Top. Valuable permanent grass as a mixture in meadows, pastures or lawns, succeeding elover and timothy when they have died out.

Kentucky Blue Grass. Most nutritious, hardy and valuable of all the northern grasses for pasture, starting early in the spring, and continuing green far into winter. In conjunction with white clover it forms a splendid lawn.

Meadow Fescue, or English Blue Grass. One of the standard European grasses. Grows two to four feet high, with broad, flat leaves, and needs rich ground.

Perennial Rye Grass. Long a stand-by with English farmers, fibrous and matlike, and does well in protecting sloping banks; will stand six or seven years.

Wood Meadow Grass. Deep green, valuable for shady places, makes a good turf, endures drought, and is good for lawns.

German or Golden Millet. Improvement on Hungarian, and should be cut just as the leaves are turning. Sown fifty pounds to the acre.

Common Millet. Two and a half to four feet high, fine bulk of stalk and leaves

\section{COW PEAS.}

\section{The Great Soil Improver, makes land more productive, a splendid and nutritious green forage and hay crop, enriching the soil after being cut off.}

Leguminous crops plowed under are the best and cheapest ways of improving soil. For this purpose the Cow Pea has no superior, especially for medium or light soils, for which it is superior to clover. It also makes a splendid green food and most nutritious hay, cutting as much as nine tons per acre, and better than corn for ensilage. They should be sown in May or June, about one and a half bushels per acre. The best variety is the Black Cow Pea. Prices on application. 


\section{POTATOES FOR SEED.}

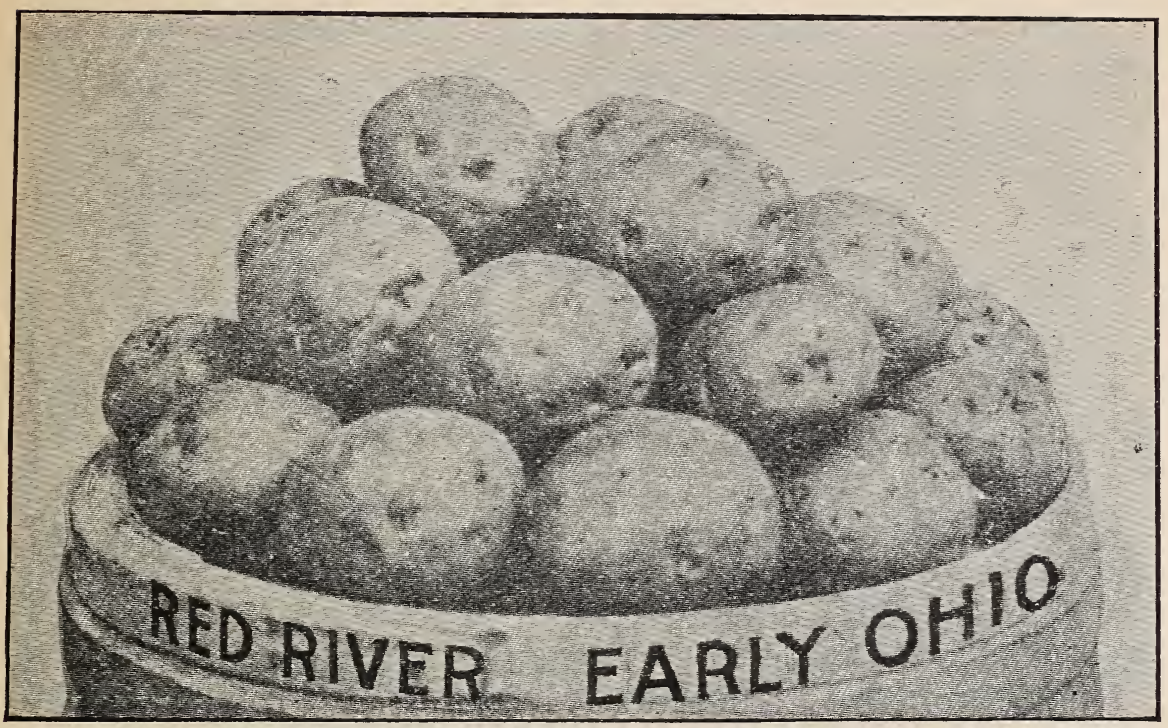

The necessity of changing Potato Seed often is admitted by all well posted growers, but too seldom practiced. By using our Northern Grown Seed you are assured of early maturity, increased yield and vigor. Our growers in the Red River district are specialists, selecting healthy seed stock and first-class potato ground, then treating the seed and spraying the foliage when necessary. The potatoes are carefully handled when digging. At the planting season's opening we can furnish all the leading standard sorts at lowest market rates.

SWEET POTATO SEED.-Our Jersey stock is specially grown and stored over winter for sprouting purposes. We have been selling this stock for several years, and find the potatoes much dryer and sweeter than those grown from Western seed. We do not ship until planting time, and prices are quoted subject to market changes:

Yellow Jerseys. 50c peck, $\$ 1.00$ 1/2 bushel, $\$ 1.50$ bushel, $\$ 3.50$ barrel.

Red Jerseys. The best of all Reds - a smooth potato with yellow meat. 60c peck, $\$ 1.00$ 1/2 bushel, $\$ 1.75$ bushel, $\$ 4.50$ barrel.

BROO и CORN-Improved Evergreen. Most popular variety in cultivation. Straw long, fine, erect and free from crooked brush. 18c lb. by mail, 3 lbs. for 45c; by express or freight, $10 \mathrm{lbs}$. for $50 \mathrm{c} ; 50 \mathrm{lbs}$. for $\$ 2.00$, or market price.

BUCKWHEAT-Common. Sown broadcast about June 20. 90c bushel.

Silver Hull. An improved variety, much better than the old sort. $\$ 1.20$ bushel.

Japanese. The grain is much larger and has a thinner hull than the other varieties. $\$ 1.00$ bushel.

RAPE-Dwarf Essex. Forage plant of high value; sown in April for an early crop, and for fall crop in July, August or September. Very rapid growth and ready to feed in ten weeks from sowing. Sheep, hogs or cattle gain weight faster on this than any other fodder, and a large crop is secured at nominal cost. Sown broadcast six pounds to the acre, or in rows $2 \frac{1}{2}$ feet apart $3 \mathrm{lbs}$. per acre. $15 \mathrm{c} \mathrm{lb} ., 100 \mathrm{lbs}$. for $\$ 10.00$.

FIELD PEAS-White Canada. As good stock as can be found in the market. Two bushels to the acre, broadcast or drilled. $10 \mathrm{c}$ quart, $40 \mathrm{c}$ peck, $\$ 1.25$ bushel,

HEMP.-For fiber, sow one-half bushel to the acre. If for seed, plant in hills four feet apart and thin out to three or four vigorous plants. $25 \mathrm{c} 1 \mathrm{~b} ., \$ 2.50$ bushel.

BIRD SEED.-Mixed Canary, Rape and Millet, 10c lb. Best Sicily Canary, 10c lb. Hemp, Millet or Rape, 10c lb. Sunflower, 10c lb. Maw or Poppy Seed, 15c lb. Lettuce Seed for birds, $30 \mathrm{c} \mathrm{lb}$. 


\section{SWEET PEAS.}

The Favorite Fragrant Flower. We are Headquarters for the Seed.

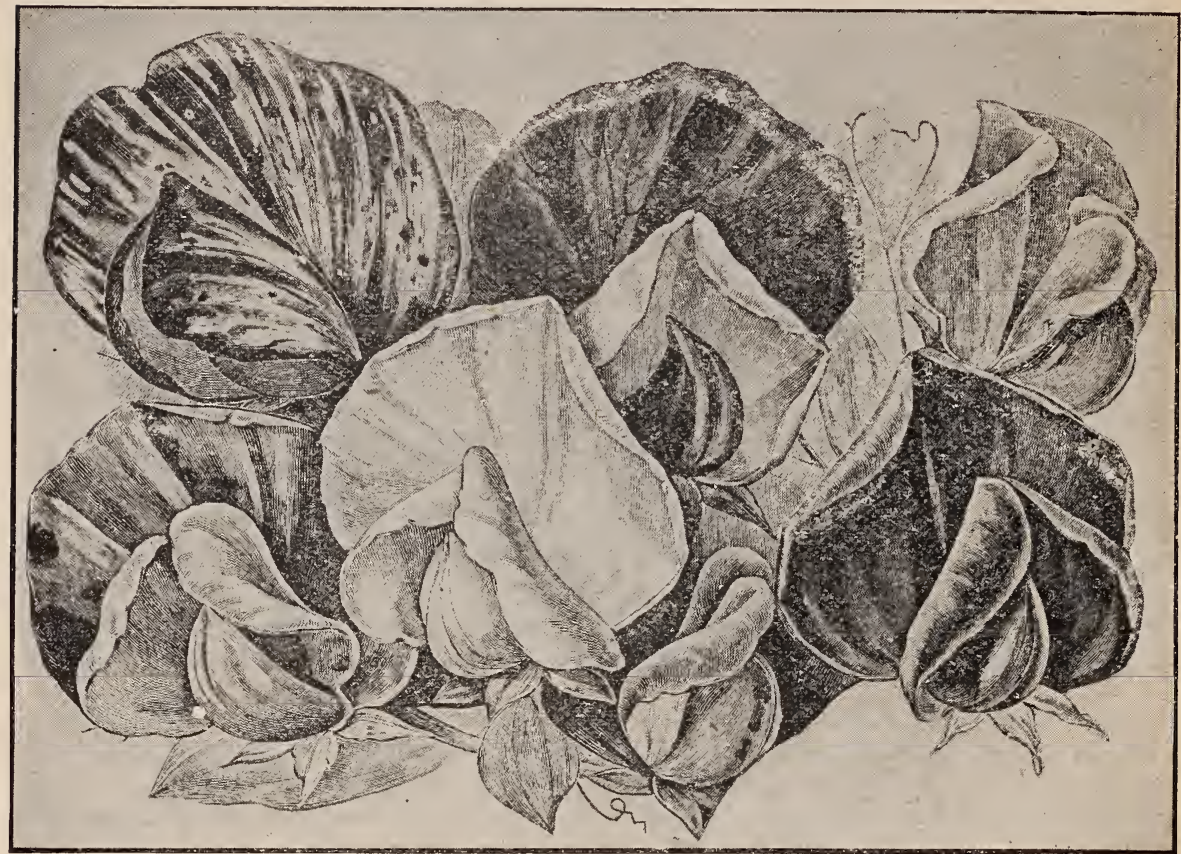

Eckford's Choice Mixed. Made up of the best sorts, with the right proportion of white, bright red, pink and other colors and shades to make a most brilliant show in the garden. $5 \mathrm{c} \mathrm{oz}, 15 \mathrm{c} 1 / 4 \mathrm{lb}, 50 \mathrm{clb}$.

New Katherine Tracy. The finest and largest; color soft but brilliant pink, with precisely the same shade in wings and standard; its perfect form and strong and vigorous plants give a wonderful profusion of flowers until the end of the season. $5 \mathrm{c} \mathrm{oz}$.

Earliest of All. Fully ten days ahead of any other; dwarf habit, two feet, needing no trellis or brush; standards a rich pink, wings nearly pure white. $5 \mathrm{coz}$.

New Extra Early Blanche Ferry. Dwarf habit, very early and has no rival for forcing; bright contrast of color, wings nearly white, standard deep rose pink. $5 \mathrm{c} \mathrm{oz}$.

Blanche Ferry. Bright pink standard, wing's nearly white, dwarf plant, early and abundant bloomer, and furnishing; flowers longer than any other sort. $5 \mathrm{c} \mathrm{oz}$.

Navy Blue. (Burpee's.) Distinct and striking rich deep blue in general effect, but the shade in the standards is deep lavender purple, with faint tint of wine red. $5 \mathrm{c} \mathrm{oz}$.

Black Knight. Large flowers, the standard rich wine brown or deep claret, wings heavily shaded with brownish-purple, turning almost black. $5 \mathrm{c} \mathrm{oz}$.

Coquette. Flowers a deep primrose tint, shaded with fawn, and suffused with a tint of purplish-rose; large standard, beautifully hooded. $5 \mathrm{c} \mathrm{oz}$.

Blanche Burpee. New large white flower, as large as Emily Henderson, with graceful stems and sprays of flowers. $10 \mathrm{coz}$.

Firefly. (Scarlet Invincible.) Flower is self-colored, deep, glowing and brightest of the scarlets. $5 \mathrm{c} \mathrm{oz}$.

Emily Menderson. Queen of England.) Persistent bloomer, flowers large and pure white, compact vine, earliest to bloom. $5 \mathrm{c} \mathrm{oz}$.

Mrs. Eckford. Beautifully shaded primrose yellow, fine form. $5 \mathrm{c} \mathrm{oz}$.

Lottie Hutchins. Large flowers of the finely expanded grandiflora type, delicately flaked with light pink on a cream ground. $5 \mathrm{c} \mathrm{oz}$.

Lady Mary Currie. Large size, standard salmon pink with sliglitly-rolled edges, wings recurved and of soft rose pink, with deep veins bordering on buff. $5 \mathrm{c} \mathrm{oz}$.

Countess of Radnor. Pale mauve standard, wings pale lilac. $5 \mathrm{c} \mathrm{oz}$. ONE OUNCE EACH of Thirteen of the above Fine Varieties for 50 Cents. 


\section{NASTURTIUM.}

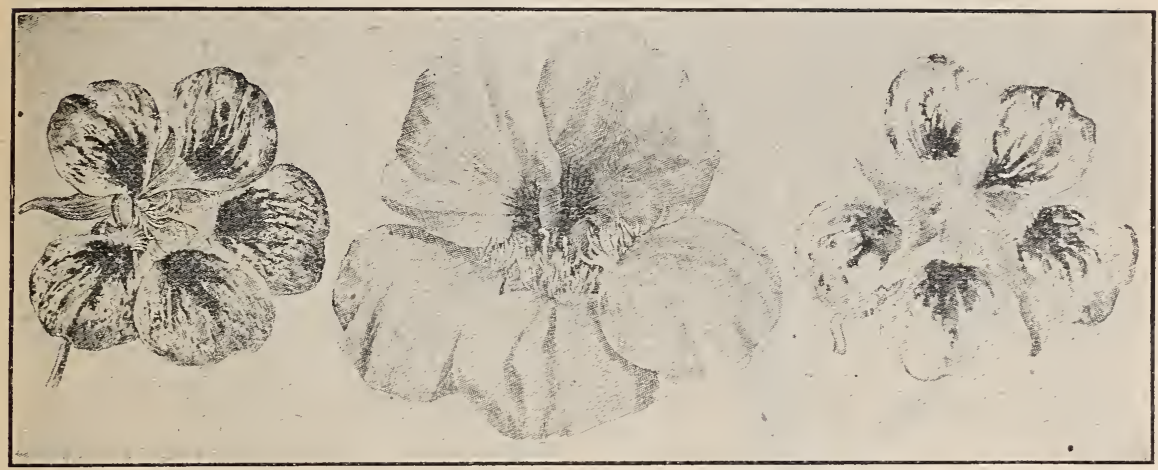

Climbing Nasturtium. (Tropæolum Majus.) Nasturtiums are among our very best climbers. They require little care, for seed sown in the spring of the year in any good garden soil, not too rich, will produce plants ten or twelve feet in height before autumn. The leaves of some rarieties are very light transparent green, while others are very dark and almost purplish. The flowers are of all shades of yellow, scarlet and spotted. The climbing Tropæolum is an excellent plant for baskets, vases, etc. Grown two or three in a large pot, with bush or lattice work support, they are very showy. Tall Nasturtiums, mixed, all colors, $5 \mathrm{c}^{1} 1 / 4 \mathrm{oz}, 15 \mathrm{coz}, 50 \mathrm{c} 1 / 41 \mathrm{~b}$. Crimson, $5 \mathrm{c} 1 / 4 \mathrm{oz}, 20 \mathrm{c} \mathrm{oz}$.

Hybrids of Madam Gunther. An entirely new strain of French origin, most remarkable for their wide range of exquisite colors, showing pink. purple, rose. salmon, light sellow, dark maroon, deep orange, etc. Also striped and blotched, mottled and rariegated in the most fantastic manner; strong grower's, climbing five to seven feet, rich dark foliage. Fine for porches, vases, or trailing on the ground. $5 \mathrm{c} 1 / 4 \mathrm{oz}, 20 \mathrm{e} \mathrm{oz}$.

Tropæolum Lobianum. Resembling the tall variety in habit, with beautiful and varied colored flowers, borne in rich profusion. The flowers and foliage are somewhat smaller than ordinary Nasturtium. $5 \mathrm{c} 1 / 4 \mathrm{oz}, 20 \mathrm{coz}$.

Tom Thumb. Our Own Special New Mixture. We have carefully selected and improved this special mixture of the most beautiful new rarieties until we are sure it is altogether unequalled-it is simply gorgeous. Such brilliant color combinations have never before been brought together. $5 \mathrm{c} 1 / 1 / \mathrm{oz}, 15 \mathrm{coz}$.

\section{POPPIES.}

Very showy, free blooming and easily cultivated plants.

Carnation Flowered. Double, brilliant, large and showy, mixed color's, 10c packet.

Single Mixed. Beautiful, all colors, large brilliant flowers. $5 \mathrm{c}$ packet, $25 \mathrm{c} \mathrm{oz}$.

NEW LARGE FLOWERED COSMOS.

Unquestionably very handsome flow ers, no other being so handsome and chaste, while it is unexcelled for keeping when cut.

Dawn. (See cut.) Pure white with rose tinge, early, dwarf, large flowers. $10 \mathrm{c} \mathrm{pkt,} 3$ for $25 \mathrm{c}$.

White, Pink and Crimson. Separate.- $10 \mathrm{c} \mathrm{pkt}, 3$ for $25 \mathrm{c}$.

Mixed. All colors, large flowering sorts. $10 \mathrm{c} \mathrm{pkt}, 3$ for $25 \mathrm{c}$.

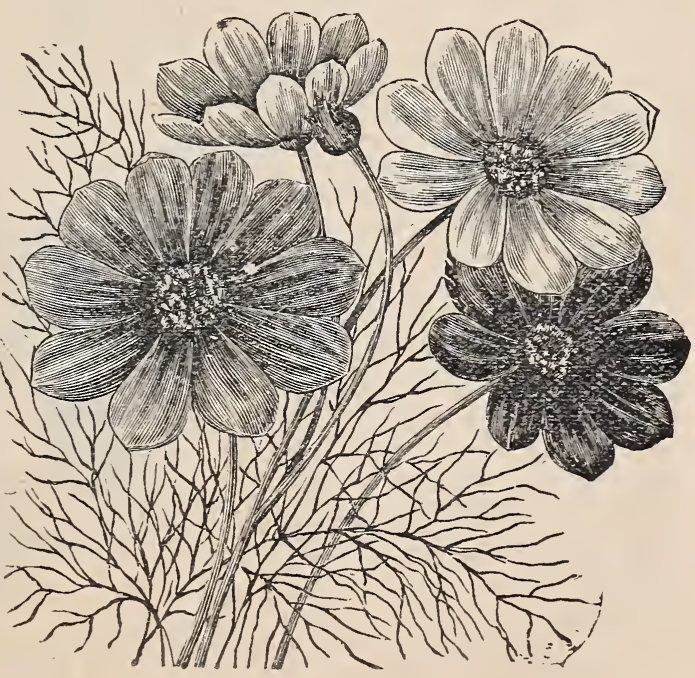




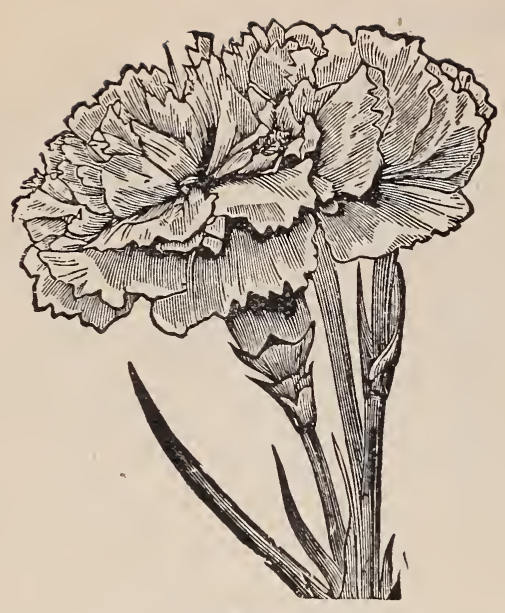

China Pink.
DIANTHUS.

(China Pink.)

A magnificent genius, embracing some of the nıost popular flowers in cultivation, producing a great variety of brilliant colors and profuse bloom the first season, very fragrant, and of easy culture. Our sced has been selected with reference to the greatest rariation of color and shape of flowers.

Chinensis. China or India Pink. Extra double, all colors mixed, 5c packet.

Heddeweggii Flore Pleno. Double Japan Pink. Seed from extra double flowers, varying from rich velvet crimson to delicaterose. All colors mixed, $10 \mathrm{c}$ packet.

Laciniatus Flore Pleno. Double Fringed Japan Pink. Large, showy flowers with fringed edges; mixed, variously colored and beautifully striped, $10 \mathrm{c}$ packet.

Imperialis. Double Imperial Pink. Finest mixed, many bright colors, 10c packet.

Barbatus. Sweet William. Single, 5c packet. Double, $10 \mathrm{c}$ packet.

Marguerite. Flowers large, fragrant, borne in great abundance, many colors. $10 \mathrm{c}$ pkt. Carnation-Finest German. IIixed colors, $25 \mathrm{c}$ packet.

\section{GIANT FLOWERED CENTAUREA.}

Royal Sweet Sultans. This new giant flower is the result of a crossing of the sweet-scented Moschata and Margaritæ; getting from the first luxuriant growth, and from the last the whole form of the flower. In color they range ${ }^{+}$hrough all the various tints of rose, white, lilac, purple, etc. Flowers are double the old size, and are deliciously fragrant and long-stemmed, rendering them of exceptional value for bouquets and vases. Strong, bushy plants about four feet high. 15c packet.

\section{IMPERIAL JAPANESE MORNING GLORY.}

Our Own Special Strain. We are able to offer a very fine mixture of choice colors, ranging through white with pink throat, white spotted with violet, white striped with rose, maure with white throat, larender with central band of crimson, cobault blue with rose bands, violet with blood red bands, crimson with carmine bands, and purple with maroon bands. Large foliage, finely cut, sometimes plain green, and occasionally green beautifully mottled with creamy buff. Sold in mixed colors only, 10c packet.

\section{PHLOX.}

Drummondii. Tery pretty hardy annual, invaluable for bedding, massing and cut flowers, from its bright colors, varying from snow white to blood red, with an unusual long blooming season. No other annual compares for beauty, duration of bloom, brilliancy of color and usefulness. Many colors mixed, $5 \mathrm{c}$ packet, $15 \mathrm{c} 1 / 4 \mathrm{oz}, 50 \mathrm{c} \mathrm{oz}$.

Large Flowering Phlox. (See cut.) The very large flowering kinds are a most decided improrement upon the Drummondii. They produce flowers almost twice the size, with the most brilliant colors that can be imagined. The plants are very hardy, of the easiest cultiration, and should be set at least one foot apart to have an opportunity to grow. Alba. Flowers of the purest white and extra large size, $10 \mathrm{c}$ packet. Scarlet. Color most intense, 10c packet.

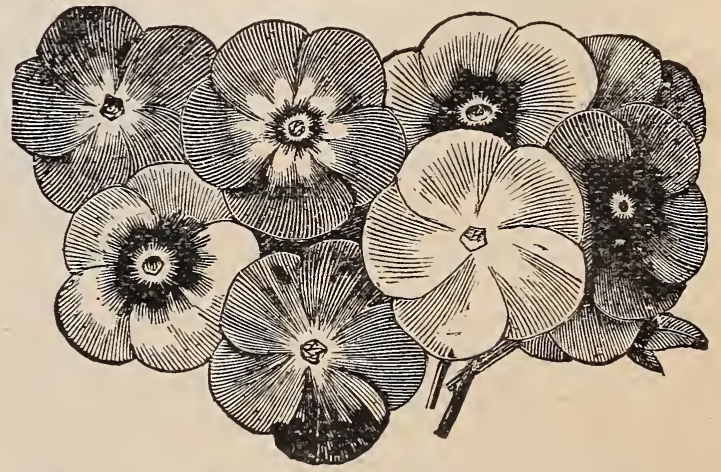

Starred and Fringed. Most distinct and striking. Mixed colors, 10c packet. 


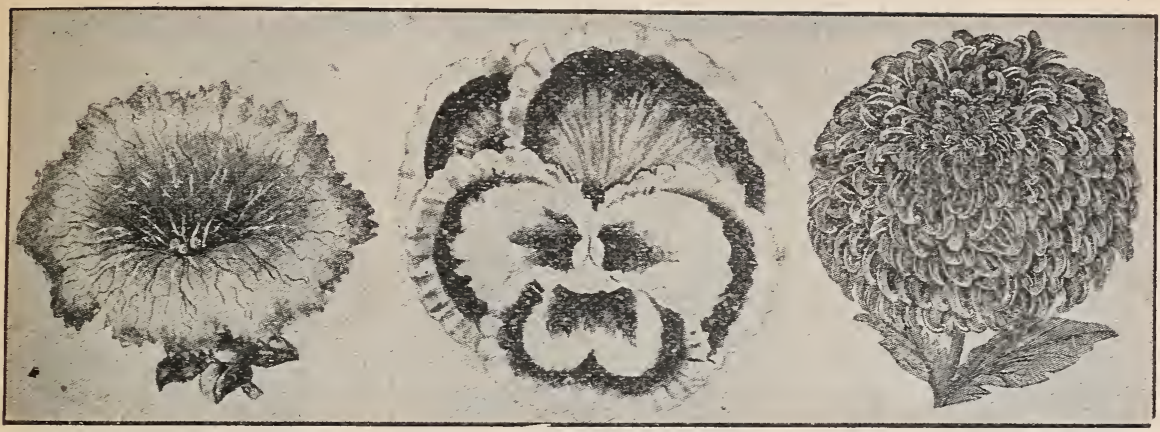

Petunia.

Pansy.

Aster.

\section{CHINA ASTER.}

Kardy annual, producing flowers of richness. profusion and variety of color, combined with perfect and beautiful form. In dry, hot weather, mulch with rotten manure and water well.

Giant Comet-Mixed. (See cut.) Flowers resemble large Japanese Chrysanthemums, petals long and twisted. Pure White, Rose and Purple, separate. $10 \mathrm{c}$ packet.

Victoria-Mixed. Large, perfectly double, imbricated and globular, pyramidal habit, rari-colored. 5c packet. Pure White and Dark Scarlet. Separate, $10 \mathrm{c}$ packet.

Mignon. Pure white, resembling the Victoria class, very profuse bloomer, flower's beautifully imbricated; 10c packet.

Vick's Branching. Late flowering and often mistaken for Chrysanthemums; extra large plants of strorg growth. White, Pink, Crimson, Purple. Separate, $10 \mathrm{c}$ plu.

Pæony Flowered. Large, double, mixed. 10c packet.

Queen of Market. Early. White, Rose, Light Blue. Separate, 10c packet.

\section{PANSY.}

Favorite with all and too well known to require any description. Seed sown in February or March in the greenhouse or sunny window will bloom freely all summer and fall. Sown in April or May they will flower in the fall. Flowers are much finer when grown in very rich soil, in a cool and partially shaded situation. Our seed is from the best strains of the most noted growers in Germany.

Odier, Trimardeau and Cassiers-Mixed. (See cut.) Distinct and beautiful new race, flowers larger than any heretofure produced, each marked by three large blotches or spots, and the plants produce an endless rariety of beautiful shades. $25 \mathrm{c}$ packet.

Improved Trimardeau Giant. Plants are of compact, robust, free-flowering habit; flower's of immense size, often measuring four inches in diameter. 10c packet.

Giant Superb Mixture. We have claimed for many years that our Superb Mixture was unapproachable, and no Pans $y$ has yet been produced of finer color, more delicate penciling, or more uniformly large in size. We have added some of the newest and most expensire strains recently produced by the growers of Hurope and America, and know that our Superb Mixture will please all lorers of the Pansy. 10c packet.

Improved German Mixed. Fine quality, $5 \mathrm{c}$ packet.

\section{PETUNIA.}

IIost desirable plants, succeeding well everywhere. They are particularly showy in beds or masses, and are universal farorites on account of their richness of color, fragrance and continuous blooming. The large flowered rarieties, often four inches in diameter. are best for single plants or little groups, and the small flowered varieties are best for showy beds. Seeds of the Double Petunia do not possess as much vitality as the single, and care must be used to get them to germinate.

New Single Large Flowering Fringed. (See eut.) A strain with fringed and frilled edges, rery distinct and beautiful, and coming true from seed; flowers rery lar'ere and deep-throated. Giants of California, pure white. Midnight, dark purple. Aurora, lar'ge throated and mixed. $25 \mathrm{c}$ packet.

Petunia Hybrida-Finest Mixed. All colors, fine for bedding or massing, and can be gromm in boxes. $10 \mathrm{c}$ packet.

Mixed. Great variety of colors and kinds, including some choice large flowering sorts. כॅc packet. 


\section{ABRIDGED LIST OF FLOWER SEEDS.}
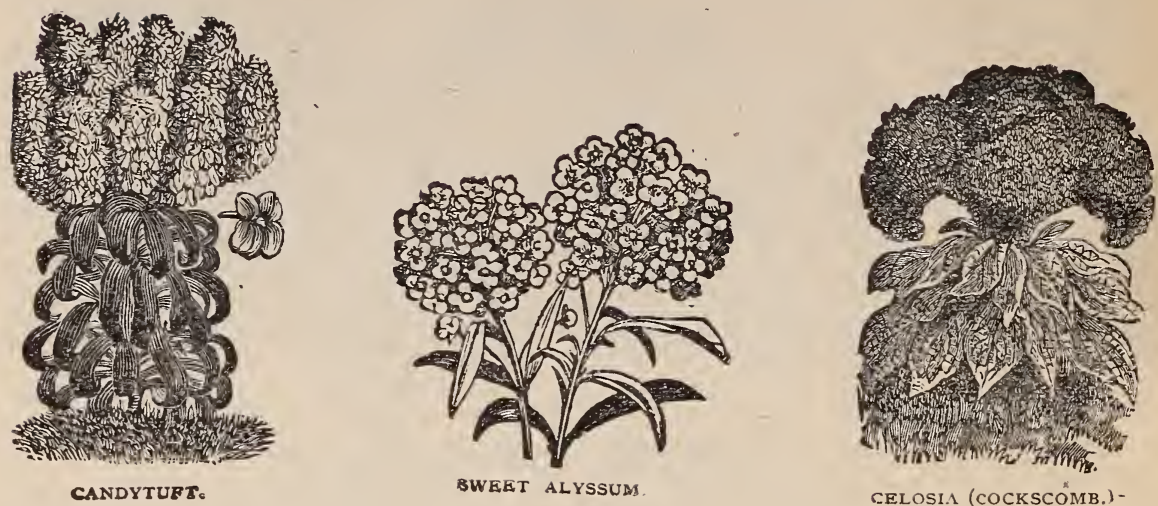

CELOSIA (COCKSCÓMB.)-

Antirrhinum. (Snap Dragon.) Half-hardy, continuous bloomer. Mixed, 5c packet. Ageratum Imperialis-Blue and White. Dwarf bedding and rase plants, raluable for large beds or borders, and very useful when cut flowers are in demand. $5 \mathrm{c}$ packet.

Alyssum, Sweet. (See cut.) Free flowering, pretty little foliage plants for bed edges; great profusion of small white flowers, delicately fragrant. $5 \mathrm{c}$ packet.

Alyssum, Procumber. Tery dwarf border sort, pure white flowers. 5c packet.

Amaranthus. (Joseph's Coat.) Tri-color, showy foliage plants, rery brilliant. 5c packet. Princess Feather. Beautiful tasseling. 5c packet.

Aquilegia. (Columbine.) Blooms freely in the spring and summer, and plant forms a large clump, which can be divided. Hardy perennial. Choice mixed, 5c packet.

Balloon Vine. (Love in a Puff.) Rapid growing climber, white blossons and seed vessels like miniature balloons. 5c packet.

Balsam. (Lady Slipper or 'Touch-me-not.) Showy and easily grown, half-hardy, delighting in bright sun and warm weather. Extra Double White, 10 pkt. Mixed, all colors and striped, 5c packet.

Balsam Pear. Most luxuriant summer climber with orange fruit. 5c packet.

Browallia-Elata Grandiflora Corulea. Elegant and free-flowering, rerbena-like, and excellent for cutting. $5 \mathrm{c}$ packet.

Calendula. (Pot Marigold.) Showy, large, flat, double flowers, of easy eultivation; hardy annual; two feet. $5 \mathrm{c}$ packet.

Canna. (See cut.) Ornamental plant, producing a rich effect. Seeds are size of bullets, and require soaking in warm water before planting. Crozy's Mixed, 5c packet.

Candytuft. (See cut.) Well known annual and considered indispensible for cutting. Rocket. Pure white, 5c packet. Mixed, all colors, 5c packet.

Celosia, or Cockscomb. (See cut.) Free flowering, showy annual, producing large, brilliant, conı-like flowers. Glasgow Prize. Fine dwarf, dark leaves and crimson comb, 5c pkt. Japonica. Tall and rery beautiful, 5c packet.

Centaurea-Cyanus Mixed. (Corn flower.) Fine for bedding, half-hardy. $5 c$ packet.

Convolvulus Major. (Morning Glory.) Hardy annual, large, mixed colors, $5 \mathrm{c}$ packet.

Cypress Vine. Graceful and beautiful twining annual, with feathery dark green foliage and crimson star-like flowers. 5e packet.

Catchfly. (Silene.) Hardy annual, nixed colors, white, red and rose. 5c packet.

Chrysanthemum-A nnual. (Painted Daisy.) Showy, easy of cultiration, and blooming early in the sunmer. 5c packet.

Castor Oil Bean. (Ricinus.) Popular tropical foliage plant, 5 to 15 feet. 5 c packet.

Cobea Scandens. An elegant summer climber, large bell-shaped flowers. 10c packet.

Clarkia. An old farorite, free flowering. hardy annual, mixed colors, 5c packet.

Delphinium. (Larkspur.) Perfectly hardy, handsome plants for border and shrubbery, splendid for cut flowers. $5 c$ packet.

Daisy. (Bellis Perennis.) Favorite plant, in bloom from April to June, and blooming can be continued by watering freely. Mixed colors, $5 \mathrm{c}$ packet.

Dusty Miller. (Cineraria-Maritima.) (See cut.) Silver-leaved perennials, much used for bedding. 5e packet.

Eschscholtzia. (California Poppy.) Leaves grayish green, large handsome flowers, two inches or more in diameter; one foot. $5 \mathrm{c}$ packet. 


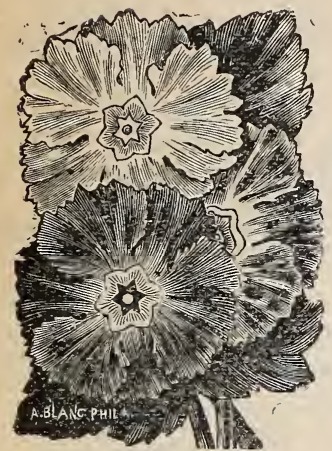

Primula-Sinensis.

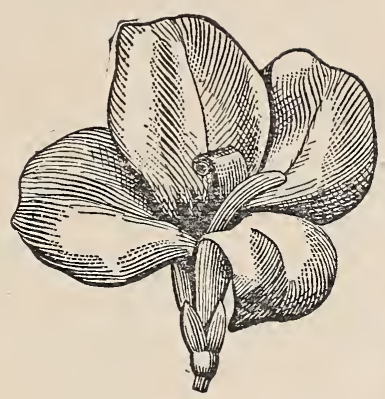

Canna.

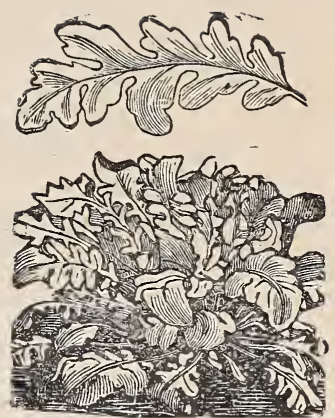

Dusty Miller:

Euphorbia. (Snow on the Mountain.) Two feet high, leaves light green and white margined, 5c packet.

Gomphrena. (Globe Amaranth or Bachelor's Button.) Handsome plants, 5c packet.

Gaillardia. Strong, constant bloomers through the whole summer, flowers large and showy: good bedding annuals. $5 \mathrm{c}$ packet.

Helianthus. (Sunflower.) Mammoth Russian, the largest of all, 5c packet. Flora Plena. Double sunflower, 5c packet. Cucumberfolio. Small, 5c packet.

Hollyhock. (Athea Rosea.) Hardy perennial; plants should be slightly protected through the winter. Choice mixed, 10c packet.

Ipomce-Grandiflora. (Moon Flower.) Large and pure white fragrant flowers opening in the evening, 10c packet.

Kennilworth ivy. A favorite drooping basket plant, 10c packet.

Lobelia. One of the finest plants for edgings and baskets, 5c packet.

Mimosa. (Sensitive Plant.) Leaves droop and close when touched, $5 \mathrm{c}$ packet.

Maurandia. Should be grown in the hotbed or greenhouse; abundant foliage, fire or six feet; flowers of good size and various colors; $5 \mathrm{c}$ packet.

Mirabilis. (Four O'clock.) Handsome, free flowering garden favorite, blooming in the evening, fragrant flowers and bright colors, $5 \mathrm{c}$ packet.

Mignonette. Very fragrant hardy little annual, $5 \mathrm{c}$ packet.

Nemophilia. Pretty, delicate, hardy annual, flowers mainly blue and white; should be sown in a frame and transplanted early into a cool place, 5c packet.

Nigella. (Love in a Mist, or Devil in a Bush.) Large flowering blooms, hardy annual, one foot, $5 \mathrm{c}$ packet.

Nicotiana. Attains a height of three feet, and at evening and early morning is covered with sweet-scented large white flowers; effective for groups; 5 c packet.

Portulaca. Dwarf, brilliant annuals, succeeding well in hot situations. Single, mixed, $5 \mathrm{c}$ packet. Double Flowered, $10 \mathrm{c}$ packet:

Primula-Sinensis. (Chinese Primrose.) (See cut.) Delicate winter blooming plants, $25 \mathrm{c}$ packet.

Salvia Splendins. (Scarlet Sage,) Bright scarlet, fall flowering, 10c packet.

Scabiosa. (Mourning Bride.) Handsome border plant. Double Mixed, 5 c packet.

Stocks. Perpetual dwarf, ten weeks, perfect flowering, fine colors. Mixed. 5c packet. Blood Red, the brightest color, double, 10c packet. Snowflake, for forcing, uncommonly large snow-white flowers, very double, 10c packet.

Tagatees. (Marigold.) Half-hardy, handsome vari-colored flowers, 5c packet.

Thunbergia. (Black-eyed Susan.) Beautiful climber. Mixed, $5 \mathrm{c}$ pkt. Alba Oculata, white with dark eyes. $5 \mathrm{c}$ pkt. Aurantiaca, orange with dark eyes, 5c packet.

Verbena. Beautiful self-colored flowers, striped and variegated. Mixed Mammoth Flowered, 10c packet. Scarlet and Pure White, separate, 10c packet. Mixed, all colors, $5 c$ packet.

Vinca. (Madigascar Periwinkle.) Bloom from early summer until destroyed by frost. and can be taken up and potted for the house. Nixed, כc packet.

Wallflower. Deliciously fragrant garden plants, finest double, $10 \mathrm{c}$ packet.

Xeranthemum. (Everlasting Flower.) Pure white, deep purple and yellow, single and double, 5c packet.

Zinnia. Showy, free flowering, easily grown; dwarf, hardy annuals, double mixed, all colors, 5c packet. 


\section{Summer and Autumn Flowering Bulbs.}

\section{GLADIOLUS.}

The most attractive of all summer flowering bulbs are the Gladioli. Wonderful improvements have been made in recent years in their size and beauty, and our list comprises only the best selections, woth in mixtures and named sorts. Their cultivation is very simple, as they will thrive in any garden soil, but amply repay care and liberal feeding by enhanced size and beauty. A succession of bloom may be had from July to September by planting at intervals from A pril to June. The strongest bulbs should be kept for the latest planting. Plant six inches apart in beds or double rows, and three inches deep. They are very effective when planted among roses, shrubbery, etc.

Snow White. Flowers of fine shape, large size, and pure paper white: spikes large and thickly set with flowers. 20c each, \$2.00 dozen.

Scarlet and Crimson. Nixed, 5 c each, 30 i dozen. White and Light. Mixed, 5c each, 50c dozen.

Yellow. 5c each, 50c dozen. Pink and Variegated. Mixed, 5c each, 40c dozen. Al! Colors. Mixed, 5c each, 30c dozen. Extra Choice. Mixed, 5c each, 40c dozer.

\section{CE If by mail, add 12c per dozen.}

\section{TUBE $=$ ROSES.}

Double Pearl. (See cut.) One of the most delightfully fragrant and beautiful summer-flowering bulbs. For early flower's start in a hot-bed or greenhouse in February or March, and for a succession plant at intervals as late as August. For the open border plant about May 1 . Choice bulbs, $5 c$ each, $25 \mathrm{c}$ per dozen. If ordered by mail, add $12 \mathrm{c}$ per dozen for postage.

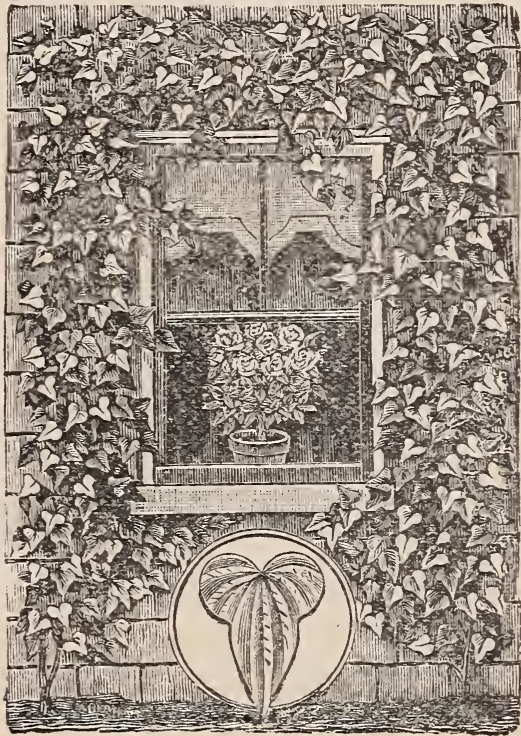

Cinnamon Vine.

\section{CINNAMON VINE.}

The most beautiful and charming of all climbers, and will quickly cover an arbor window or veranda with a great profusion of vines corered with the sweetscented flowers, making it a perfect bower of beauty. This rine is perfectly hards, and once planted will grow finely for many years, filling the air with a most delicious fragrance-a source of constant delight to every possessor. Nothing will give a house a more home-like and cosy appearance, or be a sursp index of refinement and culture than beautiful rines twining about the porch and trellises. $5 \mathrm{c}$ each, 6 for $25 \mathrm{c}$.

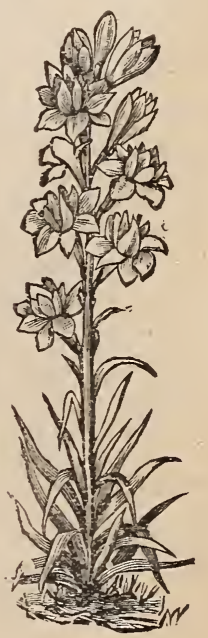

Tube= Rose. 


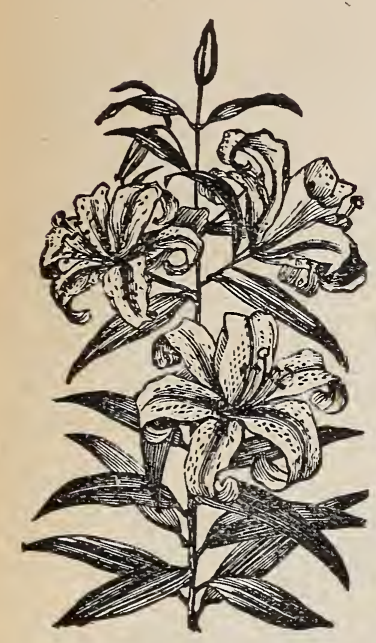

Lilium Auratum.

\section{ELEPHANT'S EAR.}

Caladium Esculentum. Very effective plant, and suitable for either a single plant on the lawn, masses in beds, or for margins of water. Its very distinct and apron-like leares often attain the length of three feet by twenty inches wide. When full size the plant stands about six feet high. They should obtain plenty of water and rich compost. The bulbs can be stored in dry sand in winter, and thus kept from year to year. Dry bulbs, $10 \mathrm{c}, 15 \mathrm{c}$ and $25 \mathrm{c}$ each. Started in pots, $15 \mathrm{c}$ to $50 \mathrm{c}$ each.

Cyclamen Giganteum. Winter-blooming bulbs $\cdot$ with variegated foliage, 15 to $50 \mathrm{c}$.

Dahlias. Named varieties, started, 25c each. Dry bulbs, 15c each. Mixed (not named) $10 \mathrm{c}$.

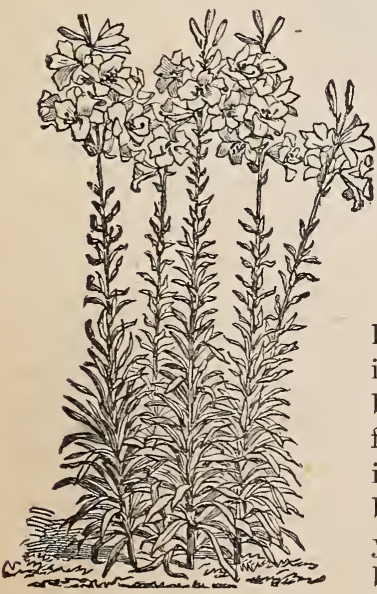

Lilium Candidum.

\section{LILIES.}

The Gold-Banded Japan Lily. Immense blooms, nearly one foot across, large white

Lium Harrissi. The Bermuda Easter Iily This now well known variety has large, trumpet-shaped, pure white in the fall, 15c each; in the spring in pots, in bud or bloom,

Richardia AEthopica. (See cut.) White Calla or Lily of the Nile. One of the best winter window plants. 15c to c each in pots.

Lilium Candidum. (See cut.) The peerless White Lily, queen of the garden. Although old and common, this is still the finest clear white flower in cultiration, and no ferer small, should be without at least one plant of this beautiful variety. Ready in September and early spring. 10c each, $\$ 1.00$ per dozen.

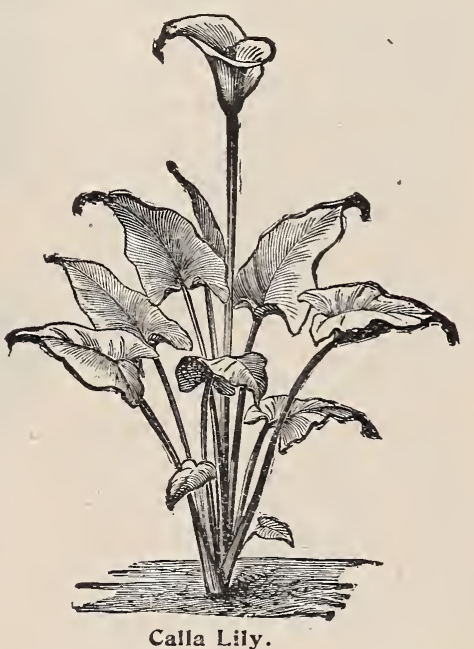

AMARYLLIS-

Johnsonii. Crimson flowers, fire inches in diameter, with striped petals. $25 \mathrm{c}$ to $\$ 1.00$ each.

Formosissimi. Dark crimson flowers. $25 \mathrm{c}$ each.

MADIERA ROOTS. (Mignonette Tine.) White flowers. $5 \mathrm{c}$ each, $35 \mathrm{c}$ dozen.

\section{ROSES.}

About the middle of April we shall have ready a rery large number of choice Roses, of the most hardy free blooming varieties, in all the different colors and kinds, including: both Hardy and Climbing Roses. These are the very best for planting out-all two years old, from eighteen to thirty inches in height, with several branches that will produce bloom. We have sold these same sized plants for several years, and they give perfect satisfaction. They are not to be compared with small mailing plants and department store "bargains." 15 c to 50 c each, $\$ 2.50$ per dozen. 


\section{HARDY SHRUBS AND VINES.}

Our Shrubs and Vines are all strong, well rooted, transplanted stock from open ground. Once carefully planted in suitable positions, they increase in size and beauty from year to year, and require but little further care. The time of bloom of the different sorts extends over nearly the whole season, but the greatest show is to be expected in the early spring and surmmer.

Ampelopsis Veitchii. (Boston Irr.) Dark green tenacious climber for ralls. 25e. Althea. (Rose of Sharon.) Double floters, summer bloomer. 25c each.

Barberry. Purple foliage, rellow flowers, blooming in the spring. 25c each.

Calycanthus. (Sweet Scented Shrub.) No garden complete without it. $25 \mathrm{c}$ earh.

Clematis-Flemula. Cream colored and fluffy flowering vine. 25c each.

Paniculata. Sweet scented and flowers nearly white. 25c each.

Jackmanii. Large purple flowers. 50c each.

Cornus. (Red Tood.) Beautiful red bark, flowers nearly white. 25c each.

Deutzia-Crenati. (Flore Plena.) Double, pink and white, fire foet. 25c each. Gracilus. Dwarf, two feet high, white and early flowered. 25c each.

Exochordia Orandiflora. New early flotrering shrub, four feet. $25 \mathrm{c}$ each.

Hydrangea Paniculata. (See cut.) Most desirable of all hardy shrubs. $25 \mathrm{c}$ each.

Honeysuckles. Desirable hardr climbing rines.

Helleana. Pure white and blooms all summer. $25 \mathrm{~s}$.

Chinese Twining. Flowers pink, blooms monthle. $25 \mathrm{c}$.

Trumpet. Old common red and rellow. 25c each.

Aurea Reticulata. Tariegated foliage, splendid plant for rases. $25 \mathrm{c}$ each.

Lilacs. Common, Thite, Persian and Purple. 25c each.

Philadelphus. (Mock Orange.) Beautiful spikes of flower's in the early spring.

Coronarius. Creamy white and weet. 25c each.

Pure White. Largest flowers, not sweet. $25 \mathrm{c}$ each.

Spirea Prunifolia. Most desirable, white flowers. $25 \mathrm{c}$.

Rhododendron. Choice named sorts, $\$ 1.00$ to $\$ 2.50$ each.

Viburnum. (Snowball.) Large flowers, $25 \mathrm{c}$ each.

Plicatum. New, small flowers, 50c each.

Wigelia-Rosea. Rose-color, ten feet high and the hardiest. $25 \mathrm{c}$ each.

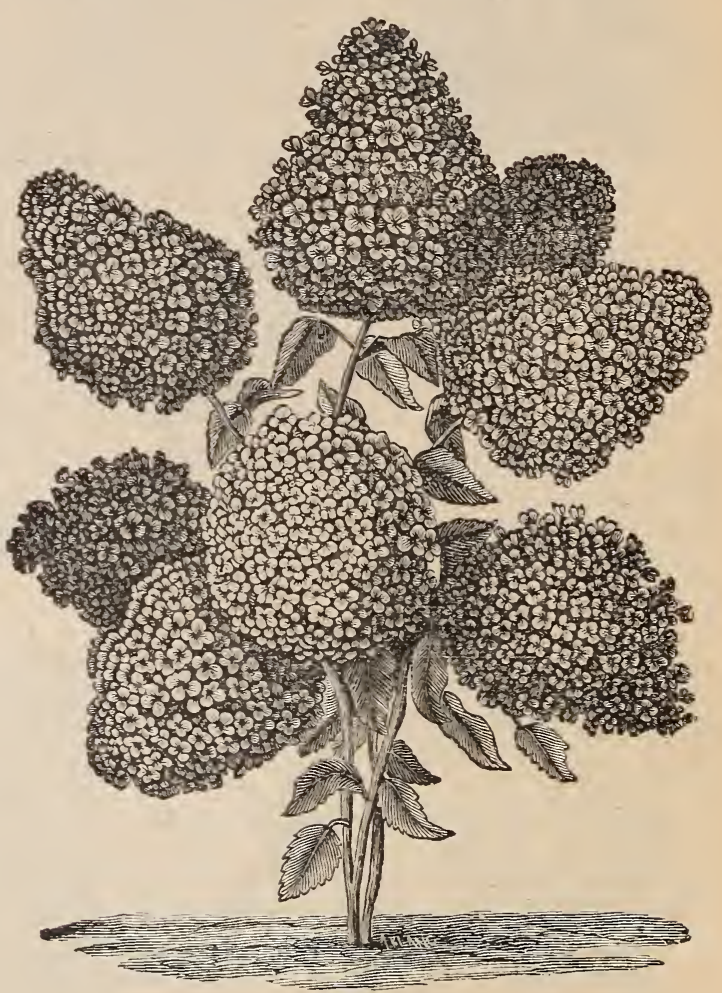

Hydrangea Paniculata.

\section{HARDY PERENNIAL PLANTS.}

Paeonia. Finest named rarieties, 35c each. Best mixed, $25 \mathrm{c}$ each.

Phlox. Hardy, best mixed, 10c each. Named varieties, $25 \mathrm{c}$ each.

Iris. Named rarieties, $15 \mathrm{c}$ each. Mixed German, 10c each. Kaempferi, $25 \mathrm{ceach}$.

Pinks-China, Sweet William, Snow, pure white, Scotch White, each 10 c per clumi).

Aquilegia. (Columbine.) Mixed color's, handsome, early bloomer. $25 \mathrm{c}$ each.

Spirea Japonica, $15 \mathrm{c}$ each. Coreopsis Lanceolate, $25 \mathrm{c}$ each.

Dialetra Spectabilis. (Bleeding Heart.) Old favorite, in every garden. 25e each.

Eulalia-Japonica. Ornamental grass, 25c. Zebrina, 25c each.

Funka-Alba. White dar lils, 25c each. Tariegated leares, blue, 25c each.

Yucca-Filamentosa. (Adam's Needle.) 25c each.

Helianthus. Hardy, double sunflower, very desirable and handsome plant. $10 \mathrm{c}$ each. 


\section{POULTRY FOOD, ETC.}

Rust's Lice-Killing Powder. For dusting roosts, nests, sitting hens, lice on fowls, horses, cattle, dogs, sheep and plants. Price, 10c per box; by mail 15c.
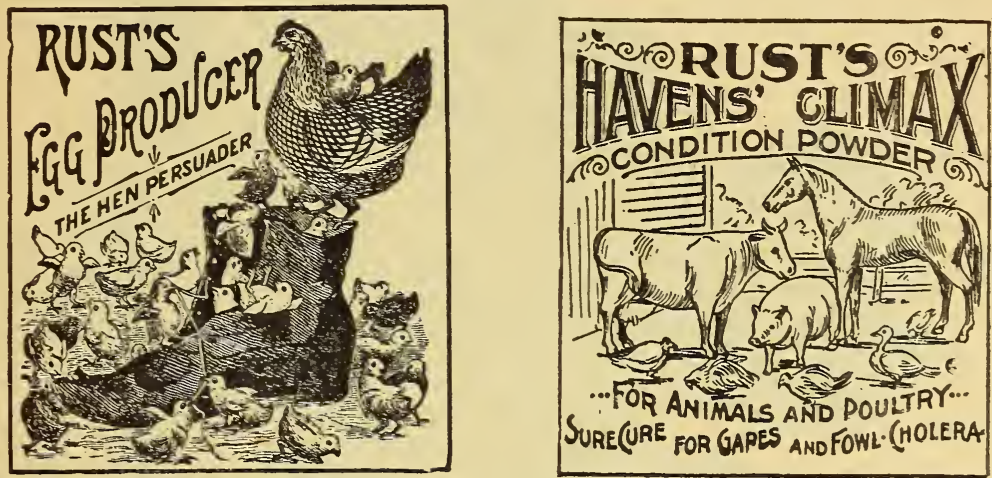

Rust's Egg Producer. Makes fowls rigorous and healthy, shortens the moulting period, prevents and cures leg weakness, etc., and just what is needed to make poultry keeping profitable. Hens must las when sou feed with it, for you are supplying just what the bird's nature needs. 1 lb. box, 25c, by mail $44 \mathrm{c} ; 2 \frac{1}{2} \mathrm{lb}$. box, $50 \mathrm{c}$, by mail $94 \mathrm{c}$.

Rust's Haven's Climax Condition Powder. An invaluable cure for gapes, fowl cholera and other diseases of poultry, and equally good for all kinds of stock. $13 \mathrm{oz}$. box $25 \mathrm{c}$, by mail 40c; $32 \mathrm{oz}$. box 50c, by mail 85c; 5 lb. box by express $\$ 1.00$.

Rust's Haven's Roup Pills. Harmless and effective, the best remedy ever discovered for roup, catarrh, colds, etc., and is a sure cure. Box of 50 pills for $25 \mathrm{c}$, mailed on receipt of price.

Crushed Oyster Shells. One of the most important articles for the poultry yard througb the winter, and should be fed liberalls to fowls to supply lime. It is nearly as good as bone, much cheaper, and should be placed where poultry can help themselves. $10 \mathrm{lbs}$. for $15 \mathrm{c}, 25 \mathrm{lbs}$. for $30 \mathrm{c}, 100 \mathrm{lb}$. sack for $75 \mathrm{c}$.

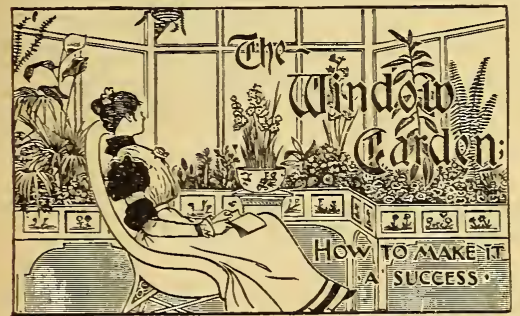

\section{HAMMOND'S SLUG SHOT.}

This is a non-poisonous powder, and for more than twenty years has prored its worth as an insecticide, and has been used in all latitudes, with absolute safety to man, beast or fowl. It is made for common use, and is a reliable article in destroying vermin in the garden. greenhouse or field. Slug Sнот kills potato bugs, currant and cabbage worms, black fleas on turnips and radishes, green flies on roses and other flowers, slugs on quiness and pears. cut. worms around cucumbers, melons and beans. worms on tomatoes and tobacco, as well as the inrripods and snails in the greenhouse. No poisonous matter can be absorbed into the leaves of fruit, and no harm can come from feeding regetables to which it has been applied. Where the insect attacks the under side of leares. Slct Shot should be applied with bellows. Ten to forts pounds to the acre. 5 lbs. 35c, 10 lbs. 50c. Perforated cartoon, filled, 15c.
WALKER'S EXCELSIOR PLANT FOOD, ertilizer for House Plants.

This compound makes them grow and bloom luxuriantly, and drives insfets from the soil. Small size package 25 cents, large size package Eben E. Rexford's "The Window Garden-How to Make it a Success.'

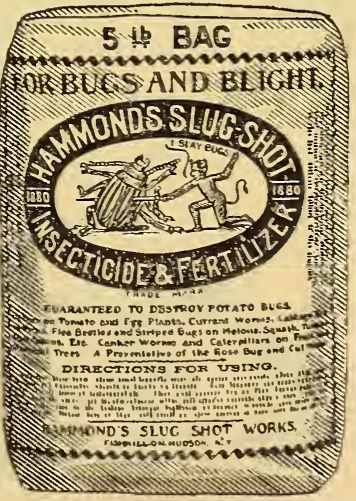




\section{IMLAY'S LAWN GRASS SEED}

Is the best for our American climate. With it you can make the Lawns, Grass Plots, Cricket Grounds, Tennis Court, etc., as soft as velvet and as green as emerald

through the whole summer.

It will form a close thick turf in a few weeks time, with no tendency to stool or grow in clumps. It roots deeply and withstands severe droughts without turning brown, nuaintaining its beautiful deep green color throughout the season. We have made the formation of permanent lawns a study for years and the finest lawns in this city today were obtained by using "Imlay's" Lawn Grass Seed, which is composed of various grasses that grow and flourish during different months of the year, so that a rich, deep green, velvety, lawn is constantly maintained, rivaling the famous lawns of Old England.

IMLAY'S LAWN GRASS SEED is, relatively speaking, the cheapest seed offered, because, while the lawn grass mixtures of other seedmen will not average over 14 pounds to the bishel, this weighs from 20 to 21 pounds per measured bushel.

If people only knew how comparatively easy it is to make a lawn with ImLAY's Lawn Grass Seed, the days of using sod, with all the attendant expense, would soon be over.

THE QUANTITY REQUIRED.-( We furnish it in large or small quantities to suit the pretentious lawn or the modest docr-yard plot.) The quantity required for making new larins is 5 bushels per acre, or for renovating old lawns, 1 to 2 bushels. For a plot $20 \times 2$ ), or 400 square feet, $1 \mathrm{lb}$. is required for new, or $1 / 2 \mathrm{lb}$. for renovating old lawns. Prices, per lb. 20c: peck (5 lbs.) 90c; bushel (20 lbs.) \$3.50. (If by mail, add at the rate of $8 \mathrm{c}$ per $\mathrm{Ib}$. for postage.)

"SHADY NOOK” LAWN GRASS.-On nearly all lawns there are unsightly bare spots under the shade of trees, which have baffled all efforts to get into grass, but with this mixture there need be no further difficulty. It is a combination of fine dwarfgrowing; ever-green rarieties, which in their wild, or natural state are to be found growing in the woods or other shaded spots. Price, per lb. $35 \mathrm{c} ; 3 \mathrm{lbs}$. $\$ 1.00$. (If by mail add at the rate of $8 c$ per lb. for postage.)

\section{“PLANET JR.” GARDEN TOOLS.}

Space will not permit illustrating and describing all of the "Planet Jr." tools, but we will gladly send a fully illustrated catalogue to any who may desire it, and we can supply promptly anything ordered. "Planet Jr." goods are standard machines and the best on the market.

The "PLANET JR." No. 4, Combined Hill Dropping Seeder and Single Wheel Hoe.

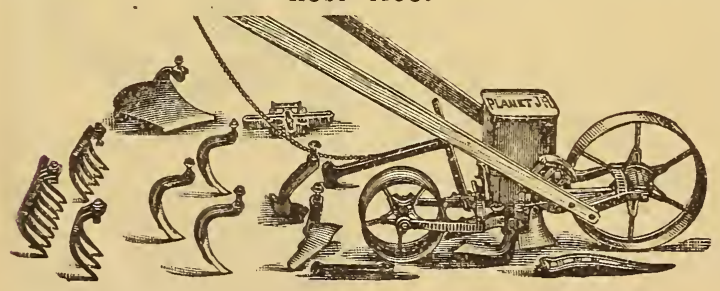

Of good size, holding two quarts, and dropping in hills at $4,6,8,12$ and 24 inches apart, and in drills any thickness, handling the smaller paper of seed perfectly, and is simple, durable and very light runving. Thrown out of gear instantly by simply raising the handles. The index is accurate, plain and easily set. The drill is detached arid the tool frame substituted by moving but one bolt. It has a fine garden plow, two new style hoes, perfected shape, three delightiful cultirating rakes, new form, and made especially to fit $6,9,12,14$ and 16 -inch rows, three cultivator teeth and a practical leaf guard. Exactly the same style of seeder as the No. 5 "Plawet Jr." Hill Dropper. 


\section{CHOICE CUT FLOWERS.}

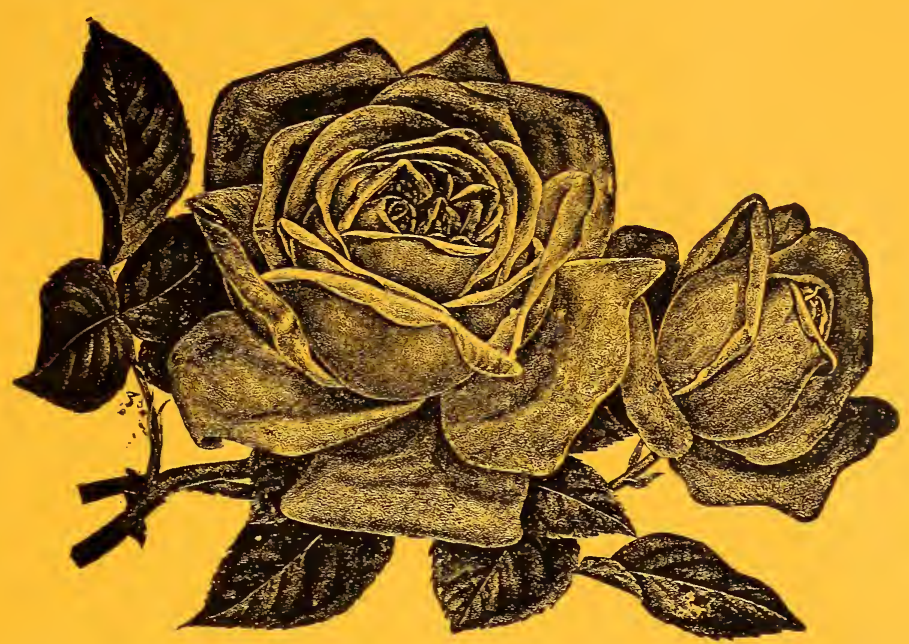

ARTISTIC AND ORIGINAL ARRANGEMENT A LEADING SPECIALTY WITH US.

Our newly improved and modern establishment, fully equipped, enables us to promptly fill orders of any extent, and certain, in an improved manner. Our established reliability and experience in the cut-flower trade gives assurance that orders will be properly filled; and as ordered. It is conceder that we excel in arrangenents of flowers suited to special uses. Competitors may imitate, but they do not, in any strict sense, follow. The necessity of entrusting orders for fine flowers and designs only to florists of known taste and ability is evident.

Quality is our aim, yet not made at undue cost. Buyers may rely on getting full value for their outlay each and every time.

Flowers in any form can be packed so that they will travel perfectly by express at any season of the year. We do this and make no additional charge for packing.

Unless able to decide specifically what is wanted when ordering flowers, an idea may be giren of the intended use; and by leaving the selection to us, we are almost sure to give satisfactory returns. We continually attend to many details of floral decorations thus entrusted to us. It is well to send orders, especially large ones for miscellaneous work, sufficiently early to allow of a second communication being received, should it be necessary.

Our trade is so large that flowers have no chance to become old. New lots are daily received from our own greenhouses and other large growers.

\section{OUR OTHER CATALOGUES.}

In addition to this General Catalogue of Flower, Garden and Farm Seeds, we issue from time to time special circulars regarding Aquariums and Gold Fish; one on House Plants, one for the Planet Jr. Garden Tools, and one of Cut Flowers and Funeral Designs-any of which we will be pleased to mail upon request, and also to quote prices at any time. 


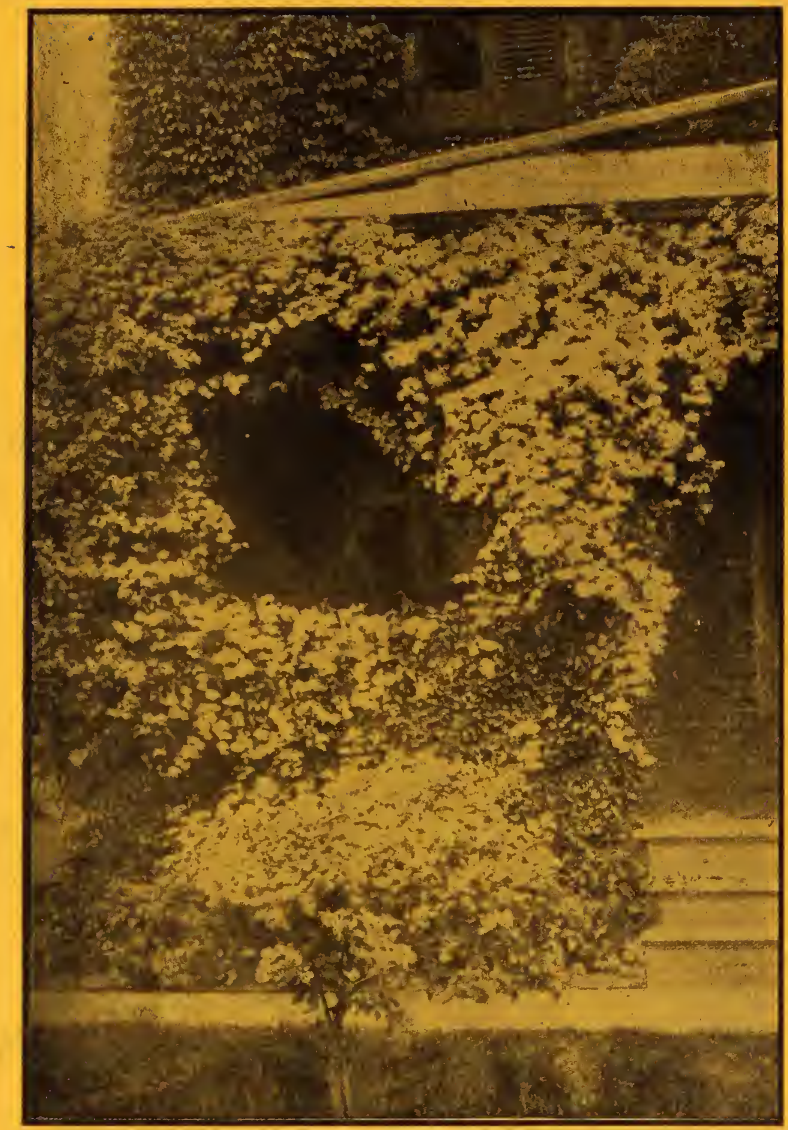

\section{CLEMATIS PANICULATA.}

A remarkably beautiful climbing plant, as shown in the above illustration. Flowers of purest white, star-shaped, about one inch in diameter, borne very freely in large clusters, and will last several days as cut flowers, retaining their freshness and fragrance. The plant is a strong, rich grower. Its luxuriant foliage, beautiful fragrant flowers, and its late blooming nature, united with entire hardiness, make this one of the most desirable and beautiful climbers. 25c. each. 